UNIVERSIDADE DE SÃO PAULO

$$
\text { ESCOLA POLITÉCNICA }
$$

PROGRAMA DE MESTRADO EM ENGENHARIA DE SISTEMAS LOGÍSTICOS

\title{
ANÁLISE OPERACIONAL E DE CUSTO LOGÍSTICO DO PROCESSO DE TRANSBORDO DE NAVIO PARA NAVIO - TRANSSHIPMENT - NO BRASIL. UMA APLICAÇÃO AO MINÉRIO DE FERRO NO PORTO DE SANTOS
}

Paula Caldo Montilha Oliveira 
UNIVERSIDADE DE SÃO PAULO ESCOLA POLITÉCNICA

PROGRAMA DE MESTRADO EM ENGENHARIA DE SISTEMAS LOGÍSTICOS

\begin{abstract}
ANÁLISE OPERACIONAL E DE CUSTO LOGÍSTICO DO PROCESSO DE TRANSBORDO DE NAVIO PARA NAVIO - TRANSSHIPMENT NO BRASIL. UMA APLICAÇÃO AO MINÉRIO DE FERRO NO PORTO DE SANTOS
\end{abstract}

Paula Caldo Montilha Oliveira

Dissertação apresentada à Escola

Politécnica da Universidade de São

Paulo para obtenção do título de Mestre em Ciências

Programa de Mestrado em Engenharia de Sistemas Logísticos

Orientador: Professor Doutor Rui Carlos Botter

SÃO PAULO

2017 
Este exemplar foi revisado e corrigido em relação à versão original, sob responsabilidade única do autor e com a anuência de seu orientador.

São Paulo, de de

Assinatura do autor:

Assinatura do orientador:

Catalogação-na-publicação

Oliveira, Paula Caldo Montilha

ANÁLISE OPERACIONAL E DE CUSTO LOGÍSTICO DO PROCESSO

DE TRANSBORDO DE NAVIO PARA NAVIO - TRANSSHIPMENT - NO BRASIL. UMA APLICAÇĀO AO MINÉRIO DE FERRO NO PORTO DE SANTOS I P. C. M. Oliveira - versăo corr. - São Paulo, 2017.

$111 \mathrm{p}$.

Dissertação (Mestrado) - Escola Politécnica da Universidade de Săo Paulo. Departamento de Engenharia de Produção.

1.Análise Operacional 2.Análise de Custo Logístico Total 3.Simulaçăo Computacional I.Universidade de Săo Paulo. Escola Politécnica.

Departamento de Engenharia de Produçăo II.t. 


\section{DEDICATÓRIA}

Dedico este trabalho aos meus pais, que nunca mediram esforços para dar aos filhos a educação que não puderam ter. 


\section{AGRADECIMENTOS}

À minha família, pela compreensão, paciência e incentivo em todo o período deste trabalho.

Ao Prof. Rui Botter por ter me escolhido na seleção do Mestrado como meu Tutor e por não desistir de mim, me orientando e motivando em momentos difíceis.

Ao Drausio Pereira por compartilhar seu vasto conhecimento sobre o Mercado Marítimo comigo, sempre com muita paciência e didática, trazendo 'uma luz no fim do túnel' em alguns momentos decisivos.

Aos amigos da USP, em especial à Juliana Magalhães, que me acompanhou durante o Mestrado e no desenvolvimento desse trabalho, e ao Tiago Novaes, que me auxiliou em várias dúvidas ao longo do desenvolvimento.

Ao time da Raízen, que fez essa jornada dupla de trabalho e estudo ser possível, em especial à Tatiana Rodrigues, e aos meus chefes durante o período.

Muito obrigada! 
"A persistência é o caminho do êxito."

Charles Chaplin 


\section{RESUMO}

A Indústria Naval tem investido em navios cada vez maiores visando ganhos de escala. Na última década, esse movimento se intensificou e um dos principais fatores é a influência significativa das economias emergentes na demanda de carga.

Alguns dos ganhos decorrentes da utilização de navios maiores são: menor consumo de energia, menor emissão de $\mathrm{CO}_{2}$, maior capacidade de carga e, consequentemente, fretes marítimos mais competitivos.

Esses novos navios acarretam a necessidade de uma revisão da infraestrutura portuária, isso porque geram uma alta concentração de carga e ainda demandam uma maior profundidade nos portos, bem como alterações nas estruturas dos terminais para recebê-los. Investimentos como dragagem, modificações de layout de terminais, entre outros, resultam em custos demasiadamente altos, além de impactos relacionados a licenciamentos para operação.

Neste cenário de aumento dos navios e da consequente dificuldade de recebê-los em diversos portos, uma solução que vem sendo utilizada ao redor do mundo é a do transbordo de navio para navio no mar, o transshipment. Ele é normalmente realizado através de um navio convertido em plataforma de transbordo/transferência, substituindo a necessidade de ancoragem do navio de maior capacidade em um terminal portuário convencional.

O Brasil tem o desafio de se preparar para este novo cenário e o porto de Santos, o principal do país, possui limitações para recebimentos destas embarcações.

Este trabalho analisou operacionalmente e sob o ponto de vista de custos logísticos, o processo de transshipment no mar em portos brasileiros. Para tal, escolheu como estudo de aplicação o minério de ferro no porto de Santos, usando como ferramentas de análise a simulação e a comparação de custos logísticos totais das alternativas.

Os resultados obtidos nas análises demonstraram a capacidade do transshipment de atender à demanda de carga em diferentes cenários e trazer uma redução de custos logísticos em relação à operação convencional.

Palavras-chave: transshipment, transbordo, mega-navios, simulação, custo logístico total. 


\begin{abstract}
The Shipbuilding Industry has invested in larger vessels for economies of scale. In the last decade, this movement has intensified and one of the main factors is that emerging economies have significantly influenced demand for cargo.

Some of the gains from the use of larger ships are: lower energy consumption, lower $\mathrm{CO} 2$ emissions, higher cargo capacity and more competitive sea freight as a consequence.

These new ships require a revision of the port infrastructure due to their higher concentration of cargo and still require a greater depth in the ports, as well as changes in the structures of the terminals to receive them. Investments such as dredging, modifications of terminal layout among others result in high costs, in addition to the need for upgrading licenses to operate.

A solution that is being used around the world is the transshipment. It is usually accomplished through a ship converted as a transfer platform, replacing the need for anchoring the larger vessel at a conventional port terminal.

Brazil needs to be prepared for this challenge and the port of Santos, the main port of the country, has limitations for receiving these vessels.

This work assessed operationally and from the point of view of logistics costs, the transshipment in Brazilian ports. To do so, it carried out an application study to the iron ore in the port of Santos, using simulation and the comparison of total logistical costs of the alternatives.

The results obtained demonstrated the capacity of the transshipment to attend the demand for cargo in different scenarios and reduce cost in relation to the conventional operation.
\end{abstract}

Key words: mega-ships, larger vessels, transshipment, ship to ship, Simulation, Total Logistics Costs. 


\section{LISTA DE FIGURAS}

Figura 1 - Tamanho dos navios de diferentes tipos. Fonte: International Transport

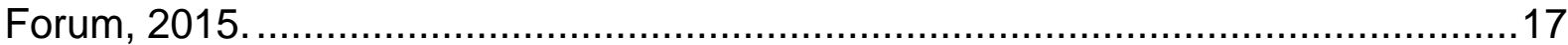

Figura 2 - Típica operação de transbordo direto. Fonte: Wang, 2015 ….................25

Figura 3 - Típica operação de transbordo indireto. Fonte: Wang, 2015 ...................26

Figura 4 - Operação de Transbordo em movimento. Fonte: Wang, 2015 ................27

Figura 5 - Navios com auto descarga. Fonte: Wang, 2015 ....................................28

Figura 6 - Navio Terminal flutuante Bulk Wayuu, da Coeclerici...............................29

Figura 7 - Guindaste Flutuante modelo Atlas 4 .................................................29

Figura 8 - navio de auto-manuseio de modelo híbrido ..........................................30

Figura 9 - Esquema de atracação em mar aberto. Adaptado de Wang, 2015. .........31

Figura 10 - Esquema de atracação em águas abrigadas. Adaptado de Wang, 2015.

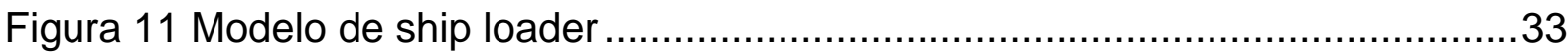

Figura 12 Desenho esquemático do sistema de Cavaletto. Fonte Wang, 2015........33

Figura 13 - Esquema de uma típica operação de transbordo usada para exportação.

Fonte: Cigolini e Rossi, 2010. 35

Figura 14 - Configuração de terminal flutuante de transbordo para contêiner. Fonte:

Baird e Rother, 2012

Figura 15 - Fluxograma para mineração do pó de ferro e transshipment para a exportação à China. Fonte: Adaptado de Brown, 2013 ...........................................38

Figura 16 - FTS - floating transshipment system. Fonte: Vale, 2015 ....................41

Figura 17 - Terminal Salineiro de Areia Branca - RN. Fonte: Wikipedia, 2015 ........43

Figura 18 - Resumo dos órgãos e legislação pertinente para o tema de transbordo

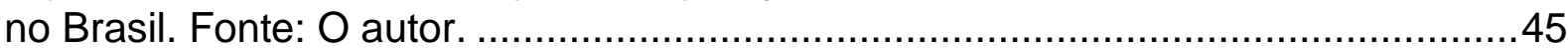

Figura 19 - Logística atual e proposta para as minas de Corumbá-MS, Fonte: Vetria, 2015.

Figura 20 Largo de Santa Rita, entre as ilhas de Bagre e Barnabé. Fonte: Google

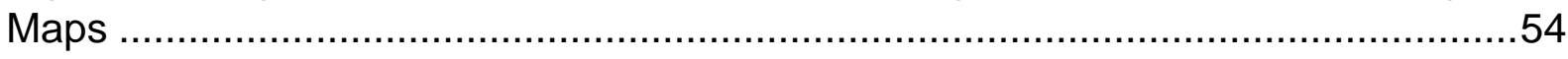

Figura 21 Modelo conceitual da operação convencional com uso de Panamax. ......59

Figura 22 Modelo conceitual da operação do navio carregador/T.U. Handymax. .....60

Figura 23 Modelo conceitual da operação do navio Capesize OGV. .60

Figura 24 - Metodologia de desenvolvimento do modelo de simulação. Chwif e Medina, 2007

Figura 25 Composição do tempo de ciclo do T.U.. .66 
Figura 26 Efeito na taxa de carregamento no tempo de espera dos navios .73

Figura 27 - Efeito de condições climáticas adversas no tempo médio de espera dos navios na barra.

Figura 28 - Efeito da distância do local do transshipment no tempo de espera dos navios na barra... 74

Figura 29 - Composição do frete marítimo. Fonte: BERTOLOTO, 2010. .79

Figura 30 - Resumo dos custos logísticos levantados para cada cenário de operação. .80

Figura 31 Resumo do custo logístico total anual dos cenários - US\$. .92 Figura 32 Principais economias e custos adicionais na operação de transshipment 93 Figura 33 - Resumo dos custos adicionais e das economias anuais da operação de transshipment. 


\section{LISTA DE TABELAS}

Tabela 1 - Tipos/Classes de navios graneleiros e suas respectivas dimensões .......58

Tabela 2 - Itens de entrada no Arena relacionados a navio. ....................................63

Tabela 3 - Itens de entrada no Arena relacionados a porto e transshipment. ............64

Tabela 4 - Resultados da simulação dos cenários (A) e (B) ..................................66

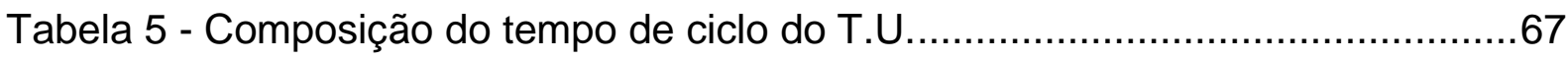

Tabela 6 - Comparação de resultados das simulações dos cenários (B) e (C).........70

Tabela 7 Comparação dos cenários B, C e D. ...................................................

Tabela 8 Comparativo entre todos os cenários de transshipment simulados. ...........72

Tabela 9 - Consumo de combustível do navio carregador. Fonte: Oldendorff, 2016.82

Tabela 10 - Resumo dos custos portuários para navio Panamax em dólares US\$.

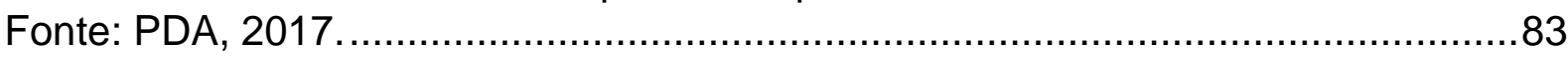

Tabela 11 - Resumo de custos portuários para navio carregador T.U. e Capesize

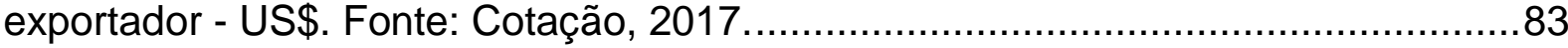

Tabela 12 - Premissas para o cálculo de demurrage / despatch..............................85

Tabela 13 - Custo logístico total anual - Operação convencional Panamax...............87

Tabela 14 - Custo logístico total anual - operação de transshipment com 2 T.U. e 1

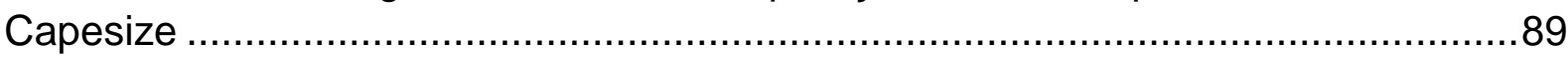

Tabela 15 - Custo logístico total anual - operação transshipment com 25\% de

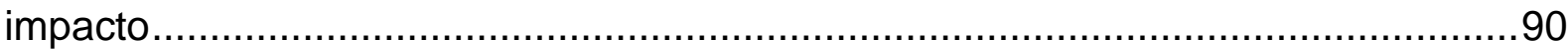

Tabela 16 - Custo logístico total anual - operação transshipment em São Sebastião$\mathrm{SP}$

Tabela 17 - Economia anual de cada cenário comparado à Operação convencional (US\$) 


\section{LISTA DE QUADROS}

Quadro 1 - Resumo de pesquisas internacionais sobre transshipment. .................39

Quadro 2 - Resumo de trabalhos nacionais sobre transshipment........................40 


\section{LISTA DE ABREVIATURAS E SIGLAS}

$\begin{array}{ll}\text { ANTAQ } & \text { Agência Nacional de Transportes Aquaviários } \\ \text { BNDES } & \text { Banco Nacional de Desenvolvimento Econômico e Social } \\ \text { CIF } & \text { Cost, Insurance and Freight (custo, seguro e frete) } \\ \mathrm{CO}_{2} & \text { Dióxido de carbono } \\ \text { CODESP } & \text { Companhia Docas do Estado de São Paulo } \\ \text { CONAMA } & \text { Conselho Nacional do Meio Ambiente } \\ \text { ETC } & \text { Estação de Transbordo de Cargas } \\ \text { FBTO } & \text { Floating Bulk Transshipment Operation (operação flutuante de carga } \\ & \text { geral com transbordo) } \\ \text { FTS } & \text { Floating Transshipment System (sistema de transbordo flutuante) } \\ \text { IBRAM } & \text { Instituto Brasileiro de Mineração } \\ \text { IN } & \text { Instrução Normativa } \\ \text { MMA } & \text { Ministério do Meio Ambiente } \\ \text { OGV } & \text { Ocean Going Vessel (navio exportador) } \\ \text { P.O. } & \text { Pesquisa operacional } \\ \text { PDA } & \text { Proforma Disbursement Account (conta portuária de desembolso) } \\ \text { SRF } & \text { Secretaria da Receita Federal } \\ \text { T.U. } & \text { Transshipment Unit (navio carregador, ou de transbordo) } \\ \text { TEBIG } & \text { Terminal Aquaviário da Baía da llha Grande } \\ \text { TUP } & \text { Terminal de Uso Privativo }\end{array}$




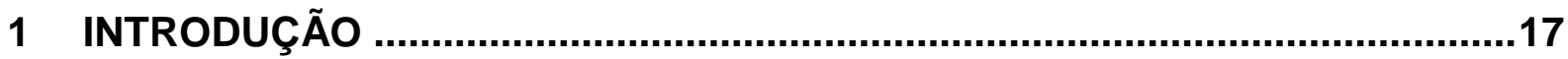

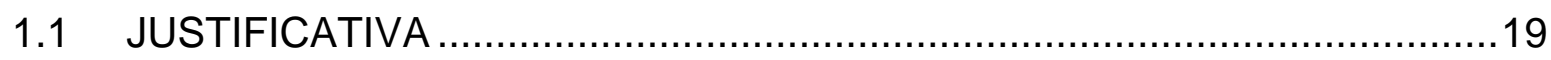

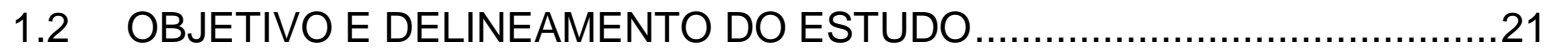

2 TRANSBORDO DE NAVIO PARA NAVIO NO MAR (TRANSSHIPMENT)........23

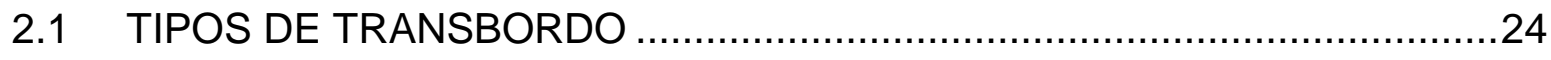

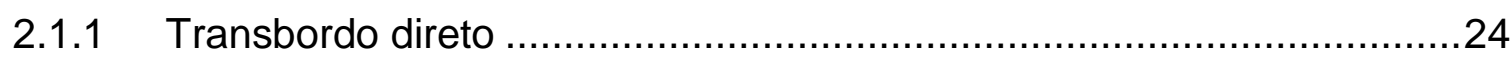

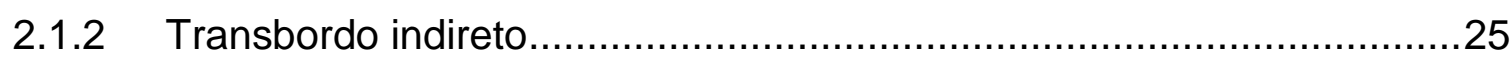

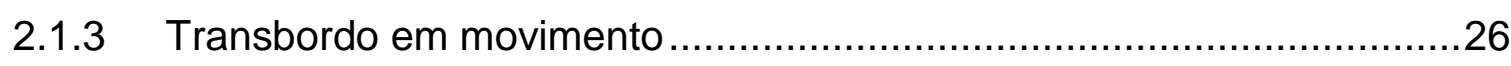

2.1.4 Transbordo com auto- carregamento / descarga..................................27

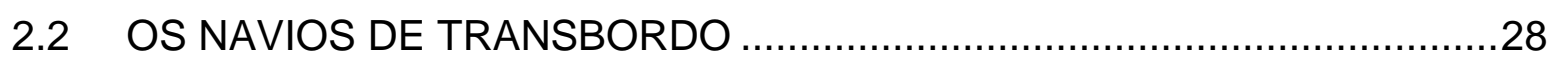

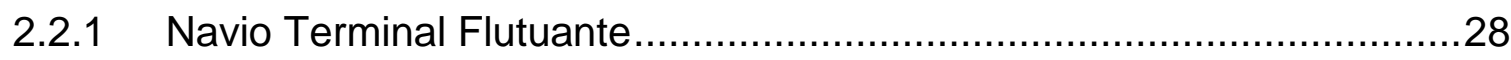

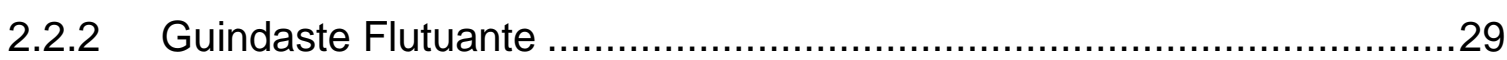

2.2.3 Navio de auto manuseio .............................................................

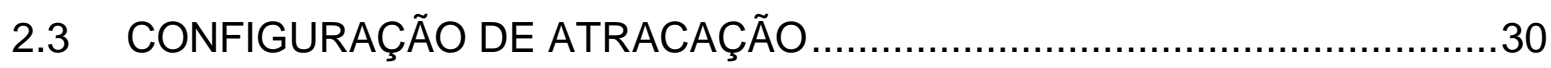

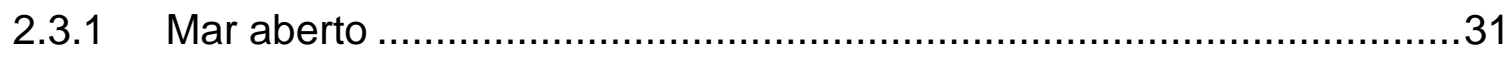

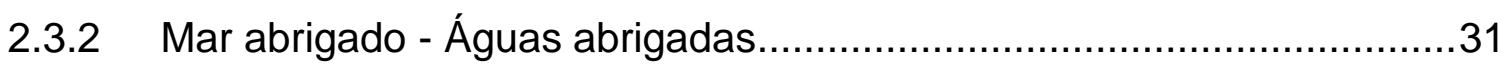

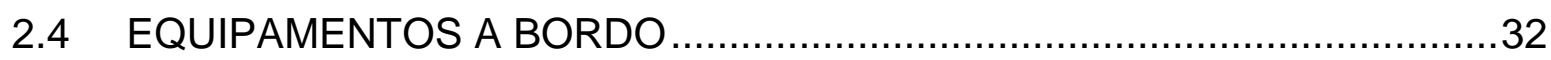

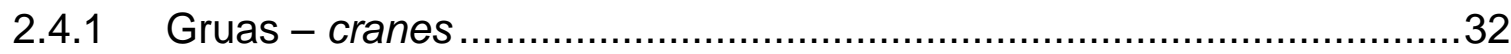

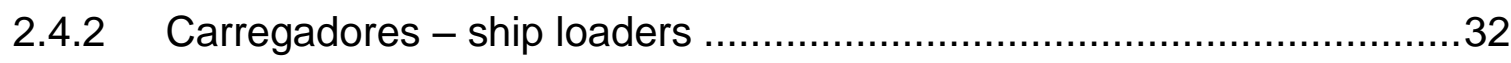

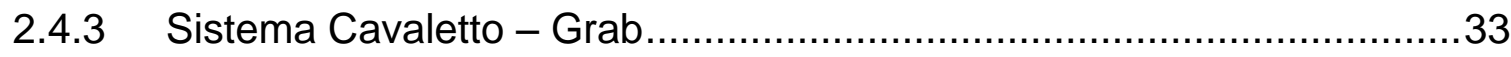

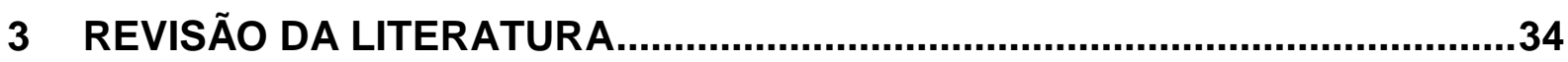

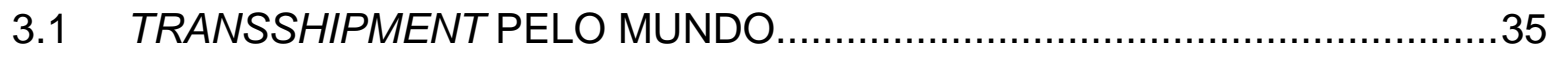

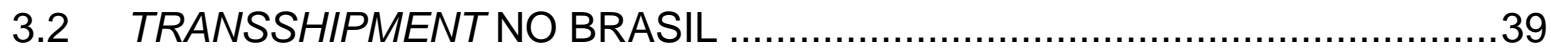

4 PROJETOS DE EMPRESAS .............................................................................

5 LEGISLAÇÃO PARA A OPERAÇÃO DE TRANSSHIPMENT ...............................44

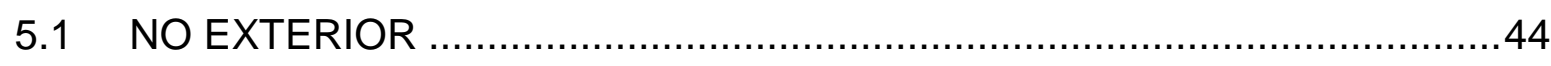

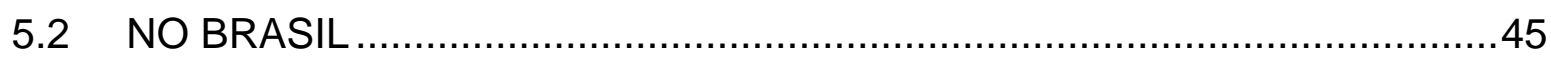

5.2.1 SRF- Secretaria da Receita Federal - Alfandegamento ........................45

5.2.2 ANTAQ - Agência Nacional de Transportes Aquaviários.......................46

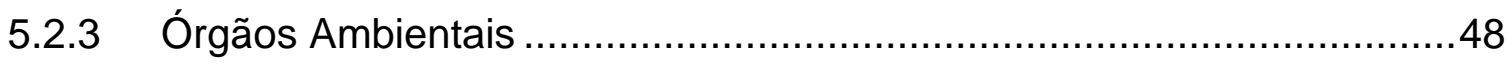

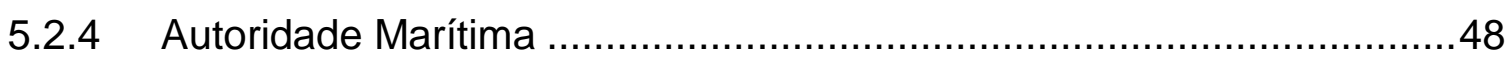

6 APLICAÇÃO AO CASO DO PORTO DE SANTOS-SP ...................................49 


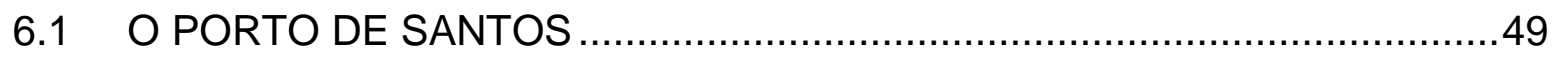

6.2 O MINÉRIO DE FERRO DE CORUMBÁ-MS ...........................................50

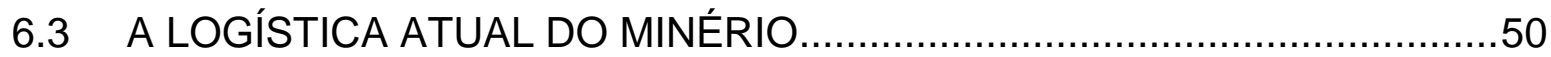

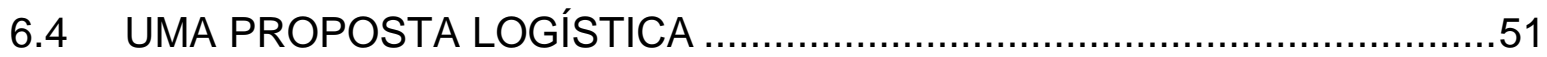

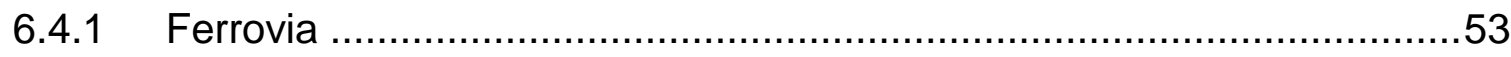

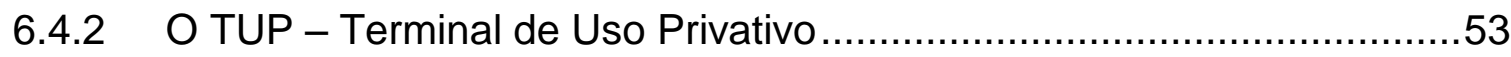

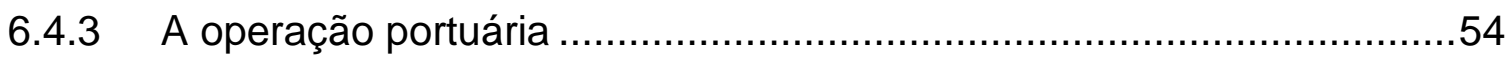

7 ANÁLISE OPERACIONAL DE UM SISTEMA DE TRANSSHIPMENT...............56

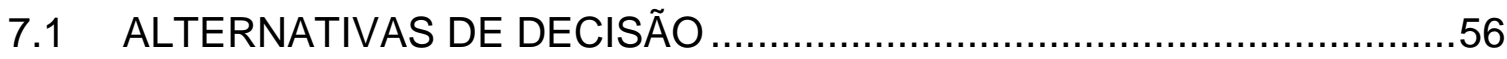

7.2 MODELO CONCEITUAL DO SISTEMA DE TRANSSHIPMENT ..............58

7.3 CENÁRIOS E PARÂMETROS ANALISADOS .........................................

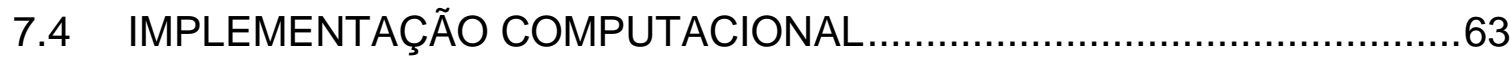

7.5 RESULTADOS DA ANÁLISE OPERACIONAL .........................................64

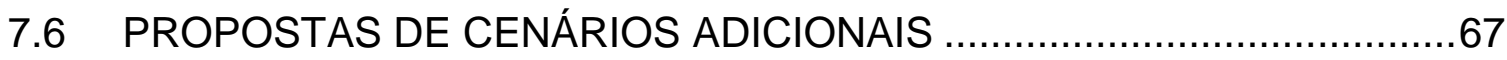

7.6.1 Cenário adicionando um carregador T.U...........................................69

7.6.2 Cenário considerando condições climáticas adversas .........................70

7.6.3 Cenário considerando operação no porto de São Sebastião-SP ...........71

7.7 ANÁLISES DE SENSIBILIDADE …………....................................

7.7.1 Efeito da taxa de carregamento na operação de transshipment.................72

7.7.2 Efeito das condições climáticas no tempo de espera dos navios ...............73

7.7.3 Efeito da distância do local do transshipment no tempo de espera dos

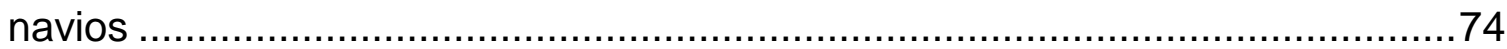

7.8 CONCLUSÕES DA ANÁLISE OPERACIONAL ......................................74

8 ANÁLISE DE CUSTO LOGÍSTICO TOTAL …............................................76

8.1 CONCEITO DE CUSTO LOGÍSTICO TOTAL.....................................76

8.2 CUSTOS LOGÍSTICOS PARA OPERAÇÕES MARÍTIMAS ....................78

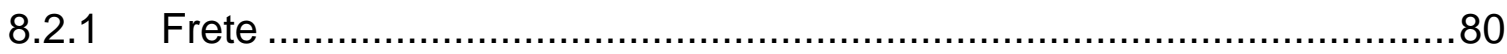

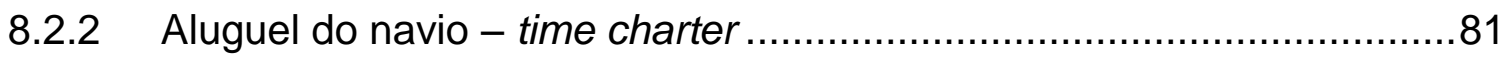

8.2.3 Despesa de combustível - bunker ……….....................................

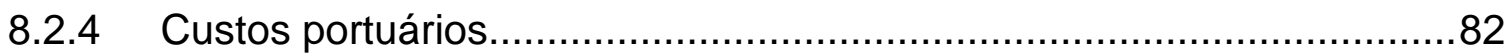

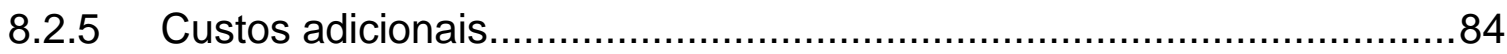

8.3 ANALISE DE CUSTO TOTAL ANUAL DOS CENÁRIOS...........................85

8.3.1 Custo logístico para a operação convencional (A) - Panamax ...................86

8.3.2 Custo logístico para o Cenário (C): transshipment com 2 T.U. e 1 Capesize 
8.3.3 Custo logístico para o Cenário (D): transshipment com impacto de condições adversas

8.3.4 Custo logístico para o cenário $(\mathrm{E})$ : transshipment em São Sebastião-SP .90

8.4 COMPARATIVO DE CUSTOS DOS CENÁRIOS .................................91

8.4.1 Principais impactos no custo total.................................................93

8.4.2 Conclusões da análise de custo total ............................................95

9 CONCLUSÕES E RECOMENDAÇÕES......................................................96

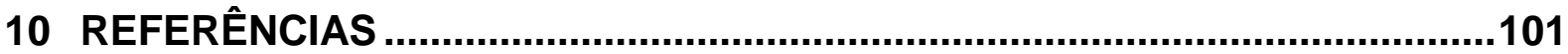

APÊNDICE A - ENTREVISTA COM PROFISSIONAL DE CORRETAGEM DE NAVIOS............................................................................................................. 105

APÊNDICE B - MODELO DO ARENA ...............................................................106

APÊNDICE C - RESULTADOS DE SAÍDA DO MODELO DO ARENA .................108

ANEXO A - DESCRIÇÕES DE DESPESAS PORTUÁRIAS ..................................109

ANEXO B: BUNKER DAILY REPORT - PETROBRAS MARINE .........................110

ANEXO C: PDA - PROFORMA DISBURSEMENT ACCOUNT ............................111 


\section{INTRODUÇÃO}

O tamanho dos navios está aumentando. A Indústria Naval tem fabricado navios cada vez maiores buscando ganhos de escala. A Figura 1 mostra a evolução do tamanho dos navios de diversos tipos ao longo dos últimos vinte anos. Observase a partir dela que, com algumas exceções, os navios em geral tem aumentado sua capacidade, principalmente aqueles dedicados a contêineres ou granéis. Esse movimento se intensificou na última década.

Alguns dos ganhos decorrentes da utilização de navios maiores são: fretes marítimos mais competitivos, menor consumo de energia e menor emissao de $\mathrm{CO}_{2}-$ dióxido de carbono, e, consequentemente, menor impacto ambiental (INTERNATIONAL TRANSPORT FORUM, 2015).

O movimento por navios maiores tem como principal objetivo o ganho em economia de escala. Os novos navios, normalmente, não apresentam grandes alterações de comprimento e largura, mas graças a proezas da Engenharia, algumas alterações em seus design são capazes de aumentar relativamente suas capacidades.

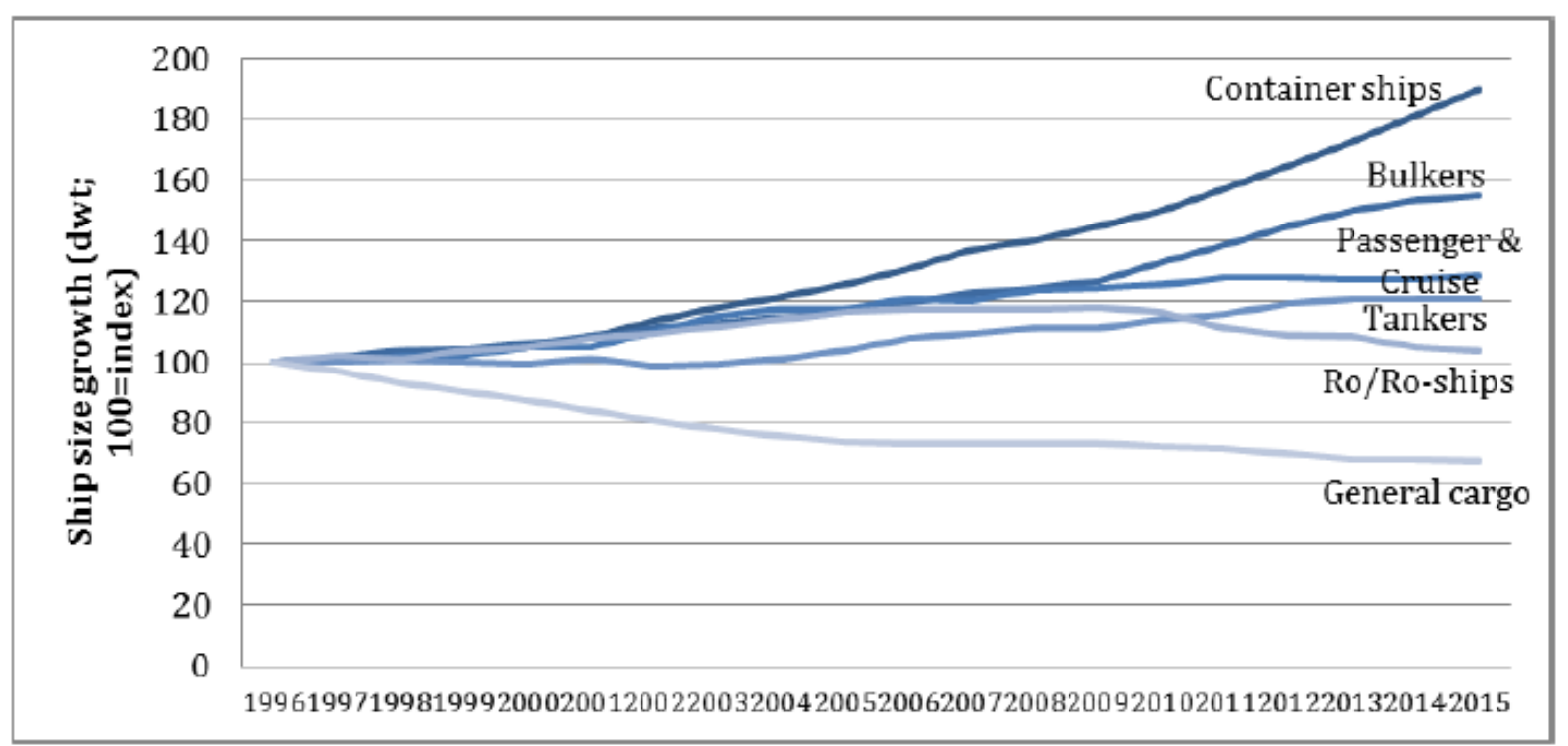

Figura 1 - Tamanho dos navios de diferentes tipos. Fonte: International Transport Forum, 2015.

O projeto dos novos navios também traz vantagens relacionadas a eficiência de energia. $O$ desenho propicia o carregamento de mais carga com baixo consumo de combustíveis, trazendo uma redução de custo variável ao Armador. 
A redução de consumo de combustível também resulta na redução de impacto ambiental, já que estas embarcações acabam por emitir menos $\mathrm{CO}_{2}$. dióxido de carbono.

Os países emergentes influenciaram significativamente o aumento de demanda de carga, principalmente a China, no comércio marítimo mundial, cujo aumento levou a uma competição maior entre os Armadores no atendimento a rotas mais longas a custos mais baixos (PORT TECHNOLOGY, 2012).

Os navios maiores, ou mega-navios, por sua vez, trazem uma necessidade de revisão da infraestrutura portuária. Isso porque devido as suas altas capacidades, resultam em a uma concentração de carga nos embarques. Estes demandam também a dragagem de determinados portos, alterações na estrutura dos Terminais e soluções criativas para que sejam bem aproveitados.

As embarcações de grandes dimensões pedem um canal mais profundo nos portos para que estes possam recebê-los. A profundidade requerida por esses navios raramente permite-lhes serem diretamente carregados e descarregados no porto (PORT TECHNOLOGY, 2012).

Umas das soluções apresentadas para se aumentar a profundidade dos canais é o conhecido sistema de dragagem. Entretanto, este sistema exige investimentos altos e custos significativos e perenes de manutenção, devido ao retorno natural dos sedimentos que foram removidos (INTERNATIONAL TRANSPORT FORUM, 2015).

O processo de dragagem enfrenta ainda diversas discussões ambientais, já que pesquisas sugerem que sua ação gera impactos irreversíveis ao meio ambiente. Castro e Almeida (2012) destacam que em regiões dragadas é possível surgirem problemas relacionados à redução de potencial pesqueiro, risco de acidentes em dutos submersos, movimentação de sedimentos contaminados para regiões limpas, entre outros.

Os navios maiores requerem também uma estrutura de terminal apropriada para recebê-los e para movimentar suas cargas. Os portos não se desenvolveram na mesma velocidade dos tamanhos dos navios (LIANG, HWANG e GEN, 2011).

Visto que muitas das estruturas portuárias foram construídas há décadas atrás, torna-se mais difícil alterá-las pelas restrições geográficas ou de espaço, além 
do fato das obras portuárias exigirem investimentos altos e em alguns casos dependerem de aprovações governamentais.

Por fim, estes mega navios comportam muito volume de carga, fazendo com que ocorra uma concentração de estoques para carregamento e descarregamento. Com isso, os terminais necessitam se preparar e refletir sobre os impactos na produtividade relacionados a estas embarcações (INTERNATIONAL TRANSPORT FORUM, 2015).

O Brasil, por sua vez, apresenta portos com problemas de infraestrutura e investimento, tornando difícil a atracação de determinados tipos de navios em alguns portos. Segundo o IPEA (2009), os portos brasileiros em geral apresentam como principais gargalos a necessidade de investimento em construção, ampliação e recuperação de infraestruturas, os acessos terrestres e a dragagem.

O porto de Santos, o principal do país, possui um canal com profundidade máxima operacional atual de 13,20 metros (CODESP, 2015) com meta de dragagem para 15 metros e largura de $200 \mathrm{~m}$, o que ainda o torna insuficiente para as embarcações maiores que estão surgindo, e nos períodos de picos de movimentação enfrenta diversas filas para atracação.

Diante da revolução que estes navios tem trazido ao setor naval, soluções criativas são necessárias para que os pontos positivos dessa inovação possam ser aproveitados a pleno e que os impactos possam ser mitigados, beneficiando a todos da cadeia.

A opção do transbordo de carga de navio para navio no mar pode ser uma solução aos problemas de profundidade, falta de capacidade portuária e altos custos e investimentos.

\subsection{JUSTIFICATIVA}

Diante do cenário de aumento dos navios e da dificuldade de recebê-los em alguns portos, seja por problemas de calado, falta de espaço ou de investimentos, uma alternativa que vem sendo utilizada ao redor do mundo é o transbordo de carga no mar (WANG, 2015). 
O transbordo no mar é muitas vezes realizado através de um navio convertido em plataforma de transbordo/transferência, substituindo a necessidade de ancoragem do mega navio em um terminal portuário convencional.

Estudos e a prática que serão detalhados neste trabalho demonstram que essa opção é viável tanto operacionalmente quanto economicamente, já que beneficia a cadeia como um todo.

Essa alternativa é amplamente usada principalmente no setor petrolífero e de granéis líquidos e recentemente está sendo estudada também para os contêineres. Há, inclusive, empresas que são dedicadas a desenhar, explorar e prestar esse tipo de serviço ao redor do mundo, como a Oldendorff, por exemplo (OLDENDORFF,2016). No Brasil, houve tentativas de se realizar esse tipo de operação, que serão expostas neste trabalho.

O Porto de Santos, o principal do país e um dos maiores movimentadores de carga da América Latina (PORTOS E NAVIOS, 2015), não apresenta canais profundos o suficiente para receber novos navios e não possui estrutura para estes em seus terminais. Ele necessita se preparar para manter seu protagonismo, já que atualmente esbarra em limites físicos.

Seu traçado possui curva acentuada que dificulta as manobras dos maiores navios com escala regular, de 366 metros de comprimento. Com a abertura do novo Canal do Panamá, a vinda das novas classes de navios deve acelerar, ainda que sejam menores que os utilizados nas rotas entre Ásia e Europa (VALOR ECONOMICO,2016).

O Porto, ainda, se localiza muito próximo à região urbana da cidade, dificultando a possibilidade de expansão de sua retroárea (PORTOS E NAVIOS, 2015).

Os investimentos na infraestrutura dos terminais portuários do Brasil são morosos e difíceis devido aos altos custos e as legislações que tornam as aprovações complicadas e demoradas, podendo levar algumas empresas a buscarem opções para este tipo de operação em países vizinhos (IPEA, 2009).

Neste contexto, analisaremos se o transbordo de cargas nos mares brasileiros e especificamente em Santos pode ser operacionalmente possível e se traz um menor custo logístico em relação a operação convencional. 


\subsection{OBJETIVO E DELINEAMENTO DO ESTUDO}

Pretende-se, com este trabalho, avaliar a viabilidade de se realizar uma operação de transbordo de cargas de navio para navio no Brasil, estudando sua realização sob os aspectos operacionais e financeiros.

O intuito é analisar operacionalmente a realização de uma operação de transshipment e compará-la com uma operação convencional, visualizando seu comportamento em diferentes configurações, seja através da quantidade de navios utilizados, dos tempos de operação, da variação de capacidade de carregamento e descarga e ainda de outros impactos que possam ocorrer. Através destes cenários, calcular os custos decorrentes deles e identificar se o transbordo se tornou viável ou não.

Sob o ponto de vista financeiro, pretende-se avaliar os custos de uma operação de transbordo do tipo e identificar se há redução de custos quando comparada a operação padrão. Como forma de se realizar esse estudo, foi pesquisado um estudo para aplicação e, dentre as possibilidades, escolhido o transbordo de minério de ferro em mar aberto, próximo ao Porto de Santos.

A autora se interessou pela opção do minério pelo fato de ser a commodity mais exportada pelo Brasil, apresentando assim um importante papel na balança comercial do país.

Em vista disto, inicialmente, foi feita uma pesquisa relacionada ao termo transbordo ou transshipment, definindo-o e classificando-o em suas diversas modalidades para o transporte marítimo. Após, foram relacionados os principais equipamentos e navios utilizados para este fim.

Em seguida, foi feita uma Revisão de Literatura, considerando referências nacionais e internacionais que já estudaram o tema, identificando suas particularidades e os pontos relevantes que contribuem com esse trabalho.

Posteriormente, foram pesquisadas as principais alternativas e metodologias utilizadas para se analisar esse tipo de operação. Para se chegar à definição do método foi necessário analisar o conceito do transporte marítimo, os diferentes tipos de terminais, os navios e equipamentos existentes e o tipo de problema a ser estudado. Isso feito, o próximo passo foi selecionar o modelo ideal para a realização da análise e obtenção dos resultados. 
Com isso, definiu-se que para a análise operacional seria utilizado o método de simulação, que consiste em elaborar um modelo de um sistema real e conduzir experimentos com este, já que o propósito da análise é compreender o comportamento do sistema e avaliar várias estratégias para a operação do mesmo. Para as simulações computacionais foi utilizado o software Arena.

Para a análise de custos, era necessária uma comparação de custos das alternativas, e, para isso, optou-se por uma comparação dos valores logísticos anuais das opções com base nos resultados da simulação, levando em consideração custos como frete, aluguel do navio, despesas de combustível, despesas portuárias, entre outros para se chegar na melhor alternativa.

O custo logístico total visa alcançar a situação ótima (maior satisfação do cliente ao menor custo) concentrando-se na redução do valor total logístico, mesmo que parte dos custos não tenham o menor valor possível.

Por fim, foram refletidas as principais conclusões obtidas através desse trabalho, bem como sugeridos alguns delineamentos futuros para o tema. 


\section{TRANSBORDO DE NAVIO PARA NAVIO NO MAR (TRANSSHIPMENT)}

O transbordo é o processo pelo qual as mercadorias são transferidas de um meio de transporte para outro e a partir deste mesmo ponto seguem para seus destinos finais. Nada mais é do que a transferência direta de mercadoria de um para outro veículo.

Este tipo de operação é realizada normalmente no transporte de mercadorias para portos ou locais de destino que não são servidos diretamente por uma linha regular de transporte, mas cujo conhecimento de transporte abrange a viagem completa na importação ou exportação (KEEDI, 2011).

No segmento marítimo, quando a transferência da mercadoria for realizada de um navio para outro da mesma empresa de navegação para seqüência da viagem, com cobertura pelo mesmo conhecimento de embarque, nunca há transferência de responsabilidade, já que muda apenas o navio e não o Armador.

Esta operação é denominada por alguns armadores como Relay, para denotar que não existe transbordo nos termos tradicionais. Tecnicamente, é um transbordo, pois a carga troca de veículo entre a origem e o destino mencionados no conhecimento de embarque.

O transbordo marítimo pode ocorrer em um terminal portuário em terra ou ser realizado no mar. Para o transbordo em terra, o navio atraca em um terminal portuário, sua carga é removida de seu interior e então carregada novamente em um outro navio que atracar neste mesmo terminal.

No caso do transbordo no mar, ele é transferido de um navio para outro sem atracar em um terminal, com a ajuda de um terceiro navio que fará o papel de carregador ou descarregador.

Esse último tipo de operação também é conhecido pelo termo em inglês transshipment ou transhipment, que segundo o dicionário inglês de Cambridge (2015) significa a atividade de transportar mercadorias a partir de um navio para outro.

A seguir serão apresentados e classificados os principais tipos de transbordo, equipamentos e navios utilizados, segundo Wang (2015). 


\subsection{TIPOS DE TRANSBORDO}

Segundo Wang (2015), do ponto de vista comercial, há dois processos em que o transshipment pode ser utilizado: na importação e na exportação. Durante cada um deles, ocorrem duas suboperações concomitantemente: o carregamento e o descarregamento. Ambas acontecem durante qualquer importação ou exportação.

A seguir serão apresentados os quatro principais tipos de transbordo existentes ao redor do mundo: o transbordo direto, o transbordo indireto, o transbordo em movimento e o transbordo com auto-descarga.

Se não for especificado abaixo, a operação deve ser assumida como sendo de granel durante a importação. Essa categorização ajuda a compreender o transbordo. Deve-se enfatizar que o transshipment é uma operação dinâmica e que está em constante melhoria e desenvolvimento. Desta forma, mais e mais tipos de operações podem estar sendo criadas ou adaptadas.

\subsubsection{Transbordo direto}

Essa modalidade envolve três ou mais navios ${ }^{1}$, sendo: o navio maior ou principal, que está contendo a carga a ser importada ou exportada, o navio alimentador, o menor para ou de onde a carga será transbordada e o navio de transbordo, que contém a grua que movimentará o produto de um navio ao outro. Este tipo de transbordo segue a relação abaixo:

$1 \times$ navio principal $+n \times$ navio de transbordo $+m \times$ navio alimentador $\quad n, m=1,2,3$

Esse tipo de operação transfere a carga do navio principal para um navio alimentador através de um navio de transbordo. Na Figura 2 é possível observar uma típica operação de transbordo direto. Nesta configuração não há armazenagem temporária, a carga segue diretamente. Ela pode ser utilizada tanto num processo de importação quanto de exportação.

\footnotetext{
${ }^{1}$ Normalmente $m \leq n \leq 3$. Número de embarcações de transbordo depende do tamanho do navio alimentador e do navio principal.
} 


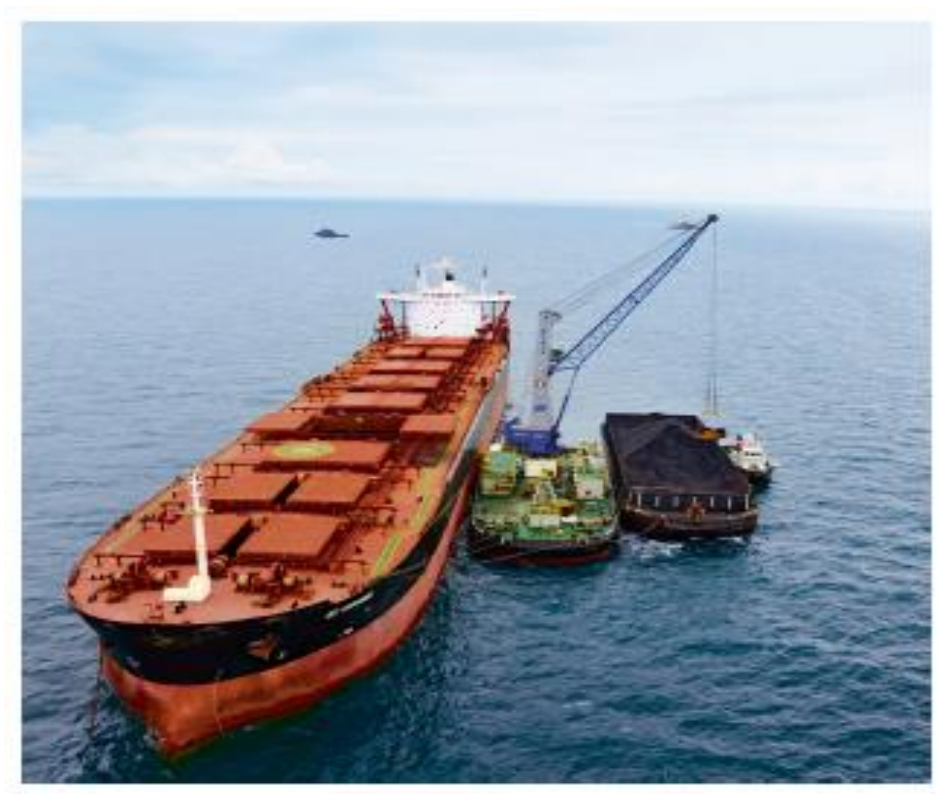

Figura 2 - Típica operação de transbordo direto. Fonte: Wang, 2015

\subsubsection{Transbordo indireto}

Normalmente envolve 3 ou mais embarcações ${ }^{2}$, que se organizam na configuração abaixo:

$1 \times$ navio principal $+1 \times$ navio de transbordo $+n \times$ navio alimentador $\quad n=1,2$

Nesta modalidade, a embarcação de transbordo possui armazenagem, conforme é possível visualizar na Figura 3. Esta embarcação também pode ser chamada carregador, terminal flutuante ou T.U. - transshipment unit. Na importação, por exemplo, a carga primeiro será descarregada do navio principal para a embarcação de transbordo para posteriormente ser transferida ao navio(s) alimentador(es).

Neste caso, também existirá o duplo manuseio, já que o navio de transferência primeiramente necessita fazer o movimento para retirada de produto e descarga em seu armazém para posteriormente fazer o segundo movimento de carregamento para outro navio.

\footnotetext{
${ }^{2}$ Usualmente na relação $\mathrm{n} \leq 2$
} 
A embarcação de transbordo também pode realizar a opção de transbordo direto, caso não exista necessidade de se armazenar produto nela, podendo ser adaptada para a operação direta.

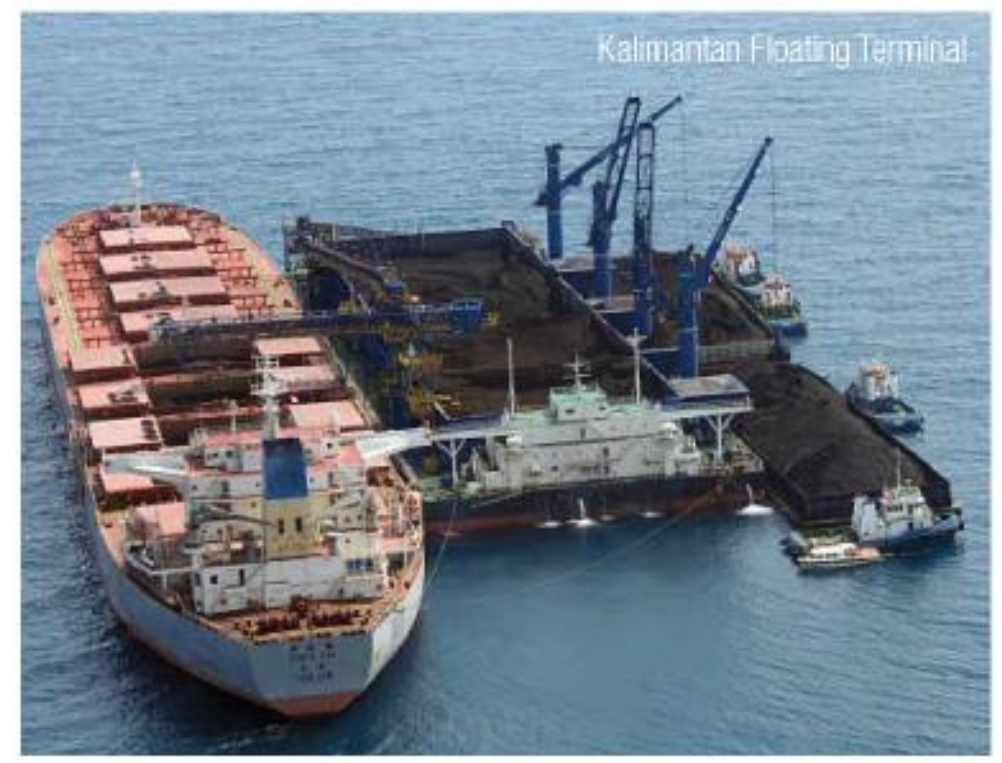

Figura 3 - Típica operação de transbordo indireto. Fonte: Wang, 2015

\subsubsection{Transbordo em movimento}

A operação de transbordo em movimento, como o próprio nome diz, é aquela em que a transferência de carga de um navio para outro ocorre com estes em movimento.

Essa operação pode ser resumida como segue:

\section{1 navio principal + $1 x$ navio de transbordo (com armazenagem)}

Essa modalidade ocorre normalmente na operação de importação, quando o navio principal chega à barra. Ambas as embarcações, principal e de transbordo, seguem no sentido do porto. Parte da carga será transferida à embarcação de transbordo para reduzir o peso e consequentemente o calado. Com isso, ambas podem navegar ao porto em terra e após o término da descarga, o navio principal poderá partir. 
A Figura 4 demonstra uma típica operação de transbordo em movimento sendo realizada, onde os navios se movimentam lado a lado enquanto realizam a transferência.

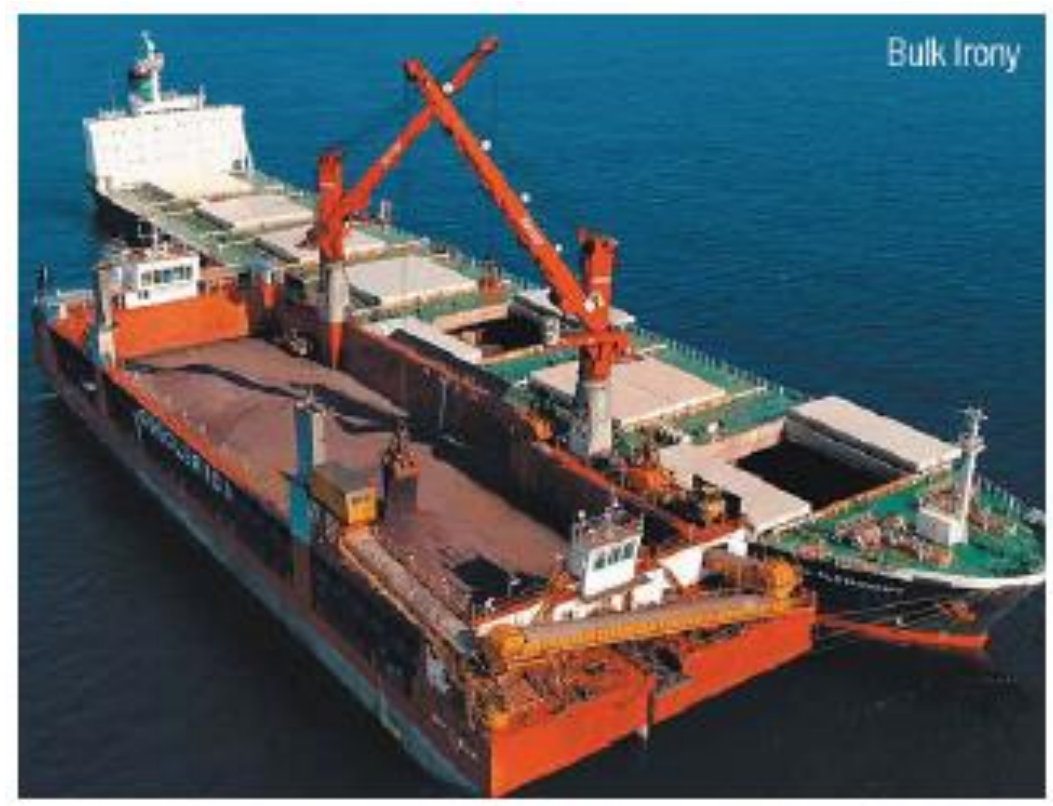

Figura 4 - Operação de Transbordo em movimento. Fonte: Wang, 2015

\subsubsection{Transbordo com auto- carregamento / descarga}

Essa operação utiliza um navio com capacidade de carga/descarga próprio, eliminando a necessidade de um navio de transbordo. Para as operações de importação, ele pode operar como navio alimentador ou descarregando diretamente no Terminal terrestre. Caso seja utilizado na exportação, trabalhará como um navio de longo curso.

Normalmente há 2 ou mais navios envolvidos ${ }^{3}$. Esse tipo de operação utiliza um navio com carga/descarga próprio, eliminando a necessidade de um navio de transbordo.

Abaixo estão listadas as duas principais configurações utilizadas neste tipo de transbordo:

Importação: $1 \times$ navio principal (com auto-manuseio) $+n \times$ navio alimentador $n=1,2,3$

Exportação: $1 \times$ navio principal $+n \times$ navio alimentador (com auto-manuseio) $n=1,2,3$

\footnotetext{
${ }^{3}$ Normalmente $\mathrm{n} \leq 3$
} 
A Figura 5 demonstra dois tipos de navios com auto-descarga.
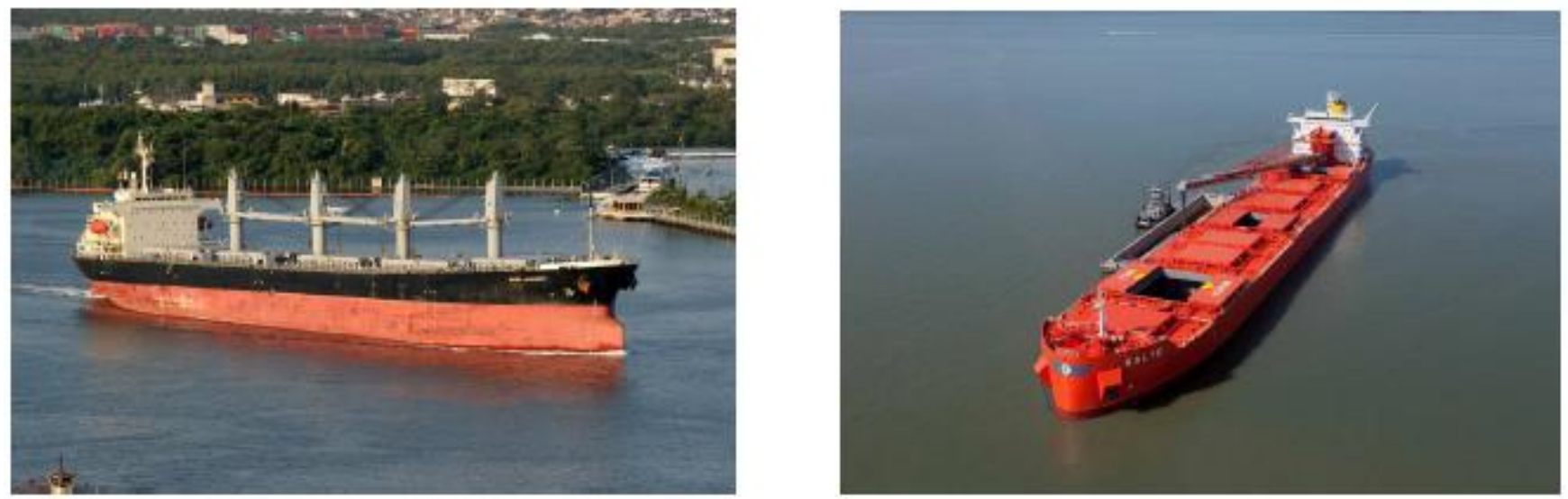

Figura 5 - Navios com auto descarga. Fonte: Wang, 2015

A imagem da esquerda demonstra um navio de auto-descarga baseado na utilização de guindaste. Já o da direita é um navio com auto-descarga baseado em gravidade.

\subsection{OS NAVIOS DE TRANSBORDO}

O trabalho de transferência de carga, normalmente, é realizado pelo navio T.U. - transshipment unit, ou navio de transbordo. Desta forma, podemos classificar essas embarcações em três tipos: Terminal Flutuante, Guindaste Flutuante e Navio de auto-manuseio.

\subsubsection{Navio Terminal Flutuante}

Para Wang (2015), as principais características destas embarcações são: design personalizado e a habilidade combinada de manuseio e entrega (podendo também possuir estocagem).

Possui os seguintes equipamentos de bordo: grua, hopper, correias, carregadores, compartimento de carga (opcional) e outros equipamentos extras, como pesagem online, separadores, etc.

A Figura 6 apresenta um navio terminal flutuante. A carga pode ser transferida para o sistema de entrega a bordo e então ser carregada nos navios alimentadores. 
A carga também pode ser temporariamente armazenada nele e então transferida aos navios alimentadores, havendo um manuseio duplo, já explicado anteriormente.

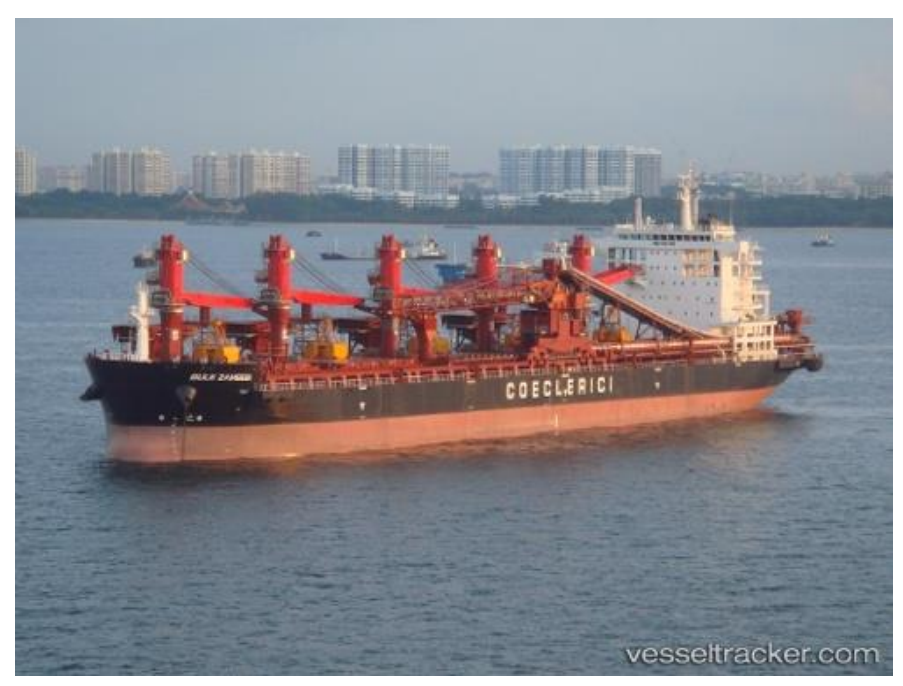

Figura 6 - Navio Terminal flutuante Bulk Wayuu, da Coeclerici

\subsubsection{Guindaste Flutuante}

A principal característica desse navio é conter um guindaste próprio para manusear a carga (WANG, 2015). A Figura 7 mostra o guindaste flutuante modelo Atlas 4.

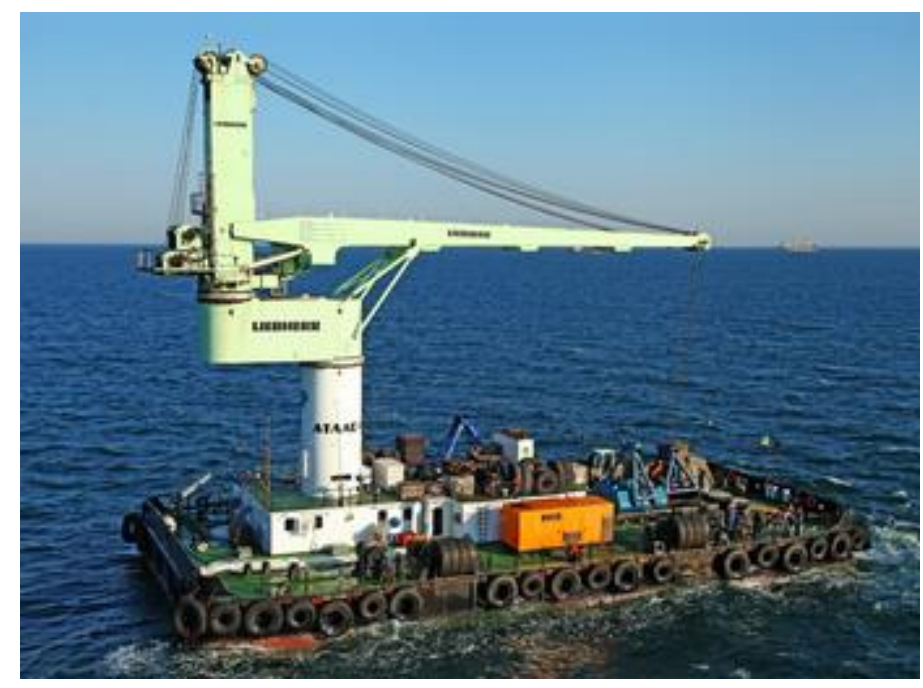

Figura 7 - Guindaste Flutuante modelo Atlas 4 
Estes possuem um desenho padrão, configurado em um guindaste flutuante montado sobre uma barcaça. Possuem uso flexível, normalmente sendo por assistido por rebocador e guincho.

\subsubsection{Navio de auto manuseio}

De acordo com Wang (2015), há diversas configurações para estes navios. Os mais comuns são: o baseado em utilização de quindaste, o baseado em gravidade (ambos já apresentados na Figura 5) e o híbrido. A figura 8 mostra o modelo híbrido.

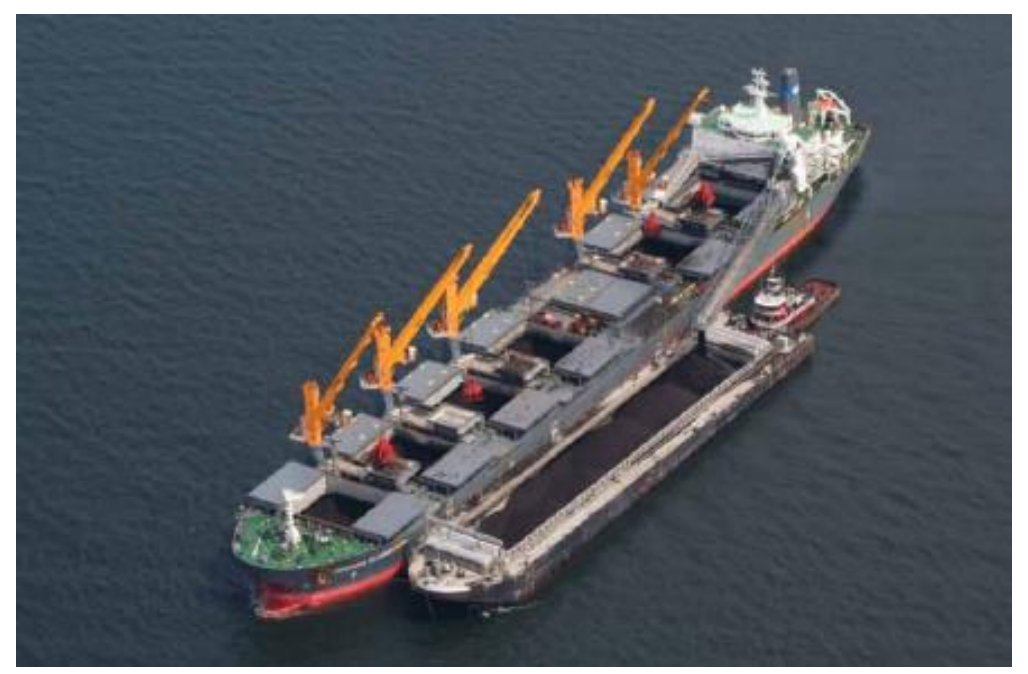

Figura 8 - navio de auto-manuseio de modelo híbrido

Esses navios, em geral, possuem a habilidade de operarem para transbordo e para transporte. Podem ser convertidos de um navio comum ou serem fabricados para tal.

O navio baseado em gravidade possui um funil de espera, um portão que usa a gravidade e uma correia transportadora. Já o navio baseado na utilização de guindaste possui o local de auto-descarga e o deck do guindaste. Por sua vez, o híbrido consegue possuir ambas as características.

\subsection{CONFIGURAÇÃO DE ATRACAÇÃO}


Segundo Wang (2015), as configurações de atracação dos navios de transbordo podem variar muito segundo seus locais de operação. A seguir serão explicadas as principais modalidades existentes.

\subsubsection{Mar aberto}

Como ilustrado na Figura 9, em operações que ocorrem em mar aberto, o navio principal é ancorado através de âncora seguindo a direção do vento. Em seguida, a grua flutuante é presa ao navio principal e à barcaça alimentadora. A operação é realizada e o rebocador auxilia o movimento da barcaça, que é responsável por levar ou trazer a carga (WANG, 2015).

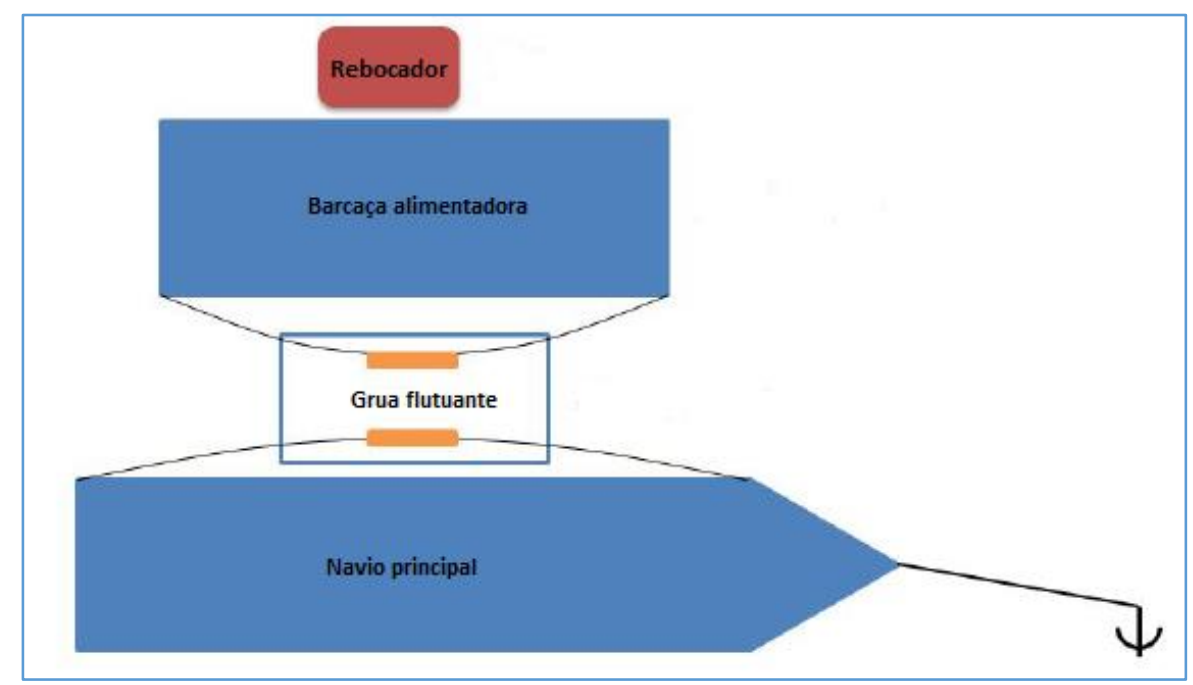

Figura 9 - Esquema de atracação em mar aberto. Adaptado de Wang, 2015.

\subsubsection{Mar abrigado - Águas abrigadas}

$\mathrm{Na}$ operação de navio para navio em mar abrigado, ou águas abrigadas, o navio principal será conectado aos dolphins, contra a direção dos ventos. Similar ao caso do mar aberto, a grua flutuante será conectada ao navio principal enquanto a barcaça alimentadora será conectada a grua flutuante, sempre que possível.

Em caso de atracação no cais, um arranjo típico que ocorre é o de conectar o navio principal aos dolphins através de linhas de atracação e então alocar as gruas flutuantes entre o navio principal e o cais. A figura 10 apresenta estas configurações. 


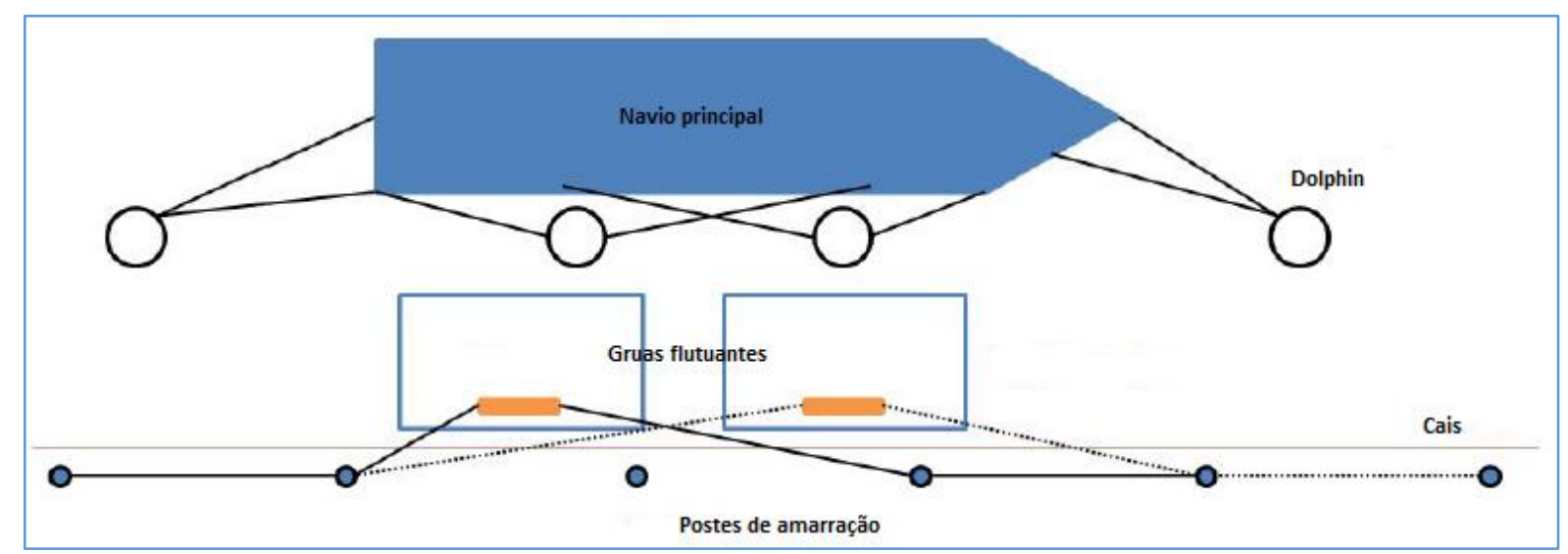

Figura 10 - Esquema de atracação em águas abrigadas. Adaptado de Wang, 2015.

\subsection{EQUIPAMENTOS A BORDO}

A seguir são apresentados alguns dos principais equipamentos de bordo que são normalmente utilizados nas operações de transbordo de granéis sólidos.

\subsubsection{Gruas - cranes}

As gruas (cranes em inglês), já mencionadas anteriormente, cumprem o papel de manusear a carga de uma embarcação para outra. No caso das gruas flutuantes, estas possuem um desenho especializado para tal, como pudemos observar na figura 7, apresentada anteriormente. As principais marcas fabricantes desses modelos são: Liebherr, Kenz-Figee, E-crane, Gottwald, MacGregor, NKM Noell (WANG, 2015).

\subsubsection{Carregadores - ship loaders}

Um carregador de navios (shiploader em inglês) é comumente usado em portos para carregamento de granéis sólidos. Pode ser montado em trilhos ou pneus, permitindo-Ihe alcançar todo o comprimento do navio. A Figura 11 exibe um modelo de shiploader. 


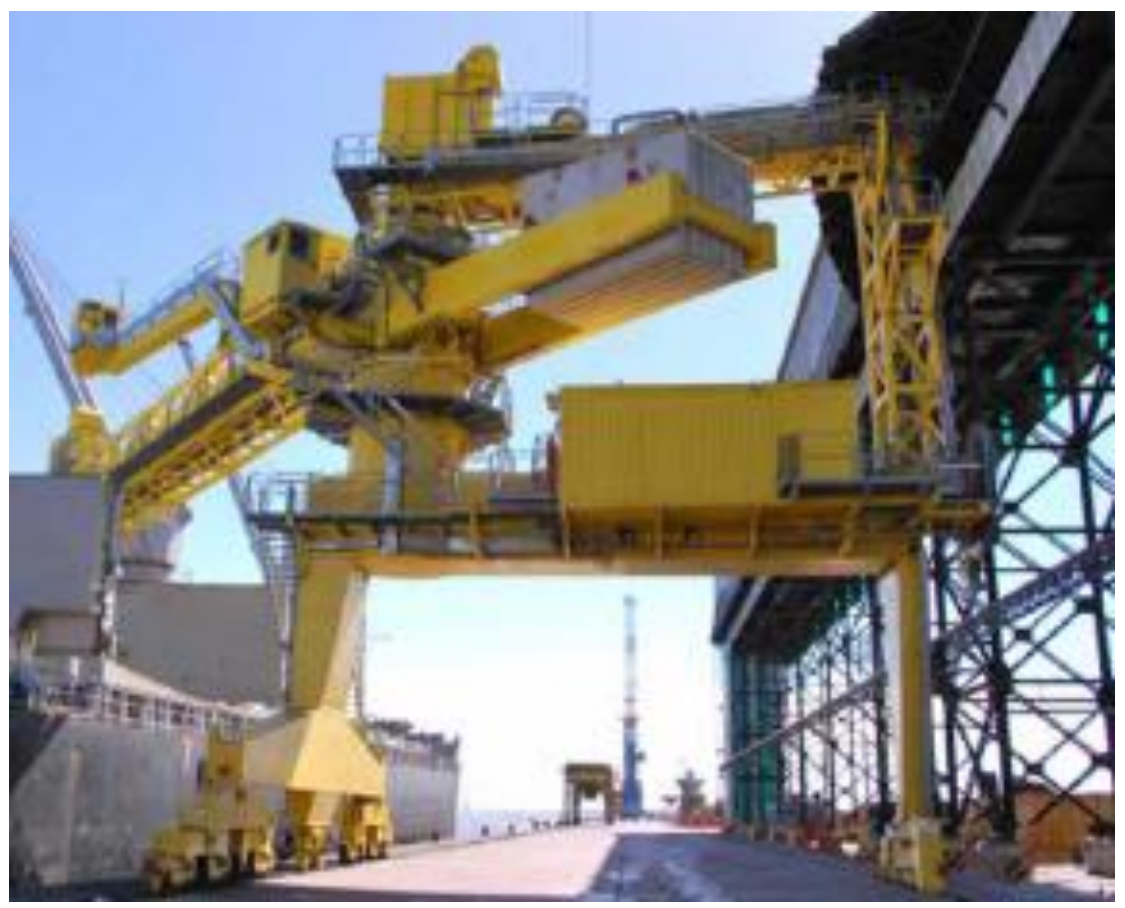

Figura 11 Modelo de ship loader

\subsubsection{Sistema Cavaletto - Grab}

O Sistema Cavaletto, também chamado de grab, é adaptado especialmente para a transferência de grandes volumes de carga. Ele consiste em uma grua, um funil, uma correia transportadora e um espaço de descarga. É utilizado, por exemplo, pela empresa Coeclerici. A Figura 12 mostra o desenho de um Sistema Cavaletto.

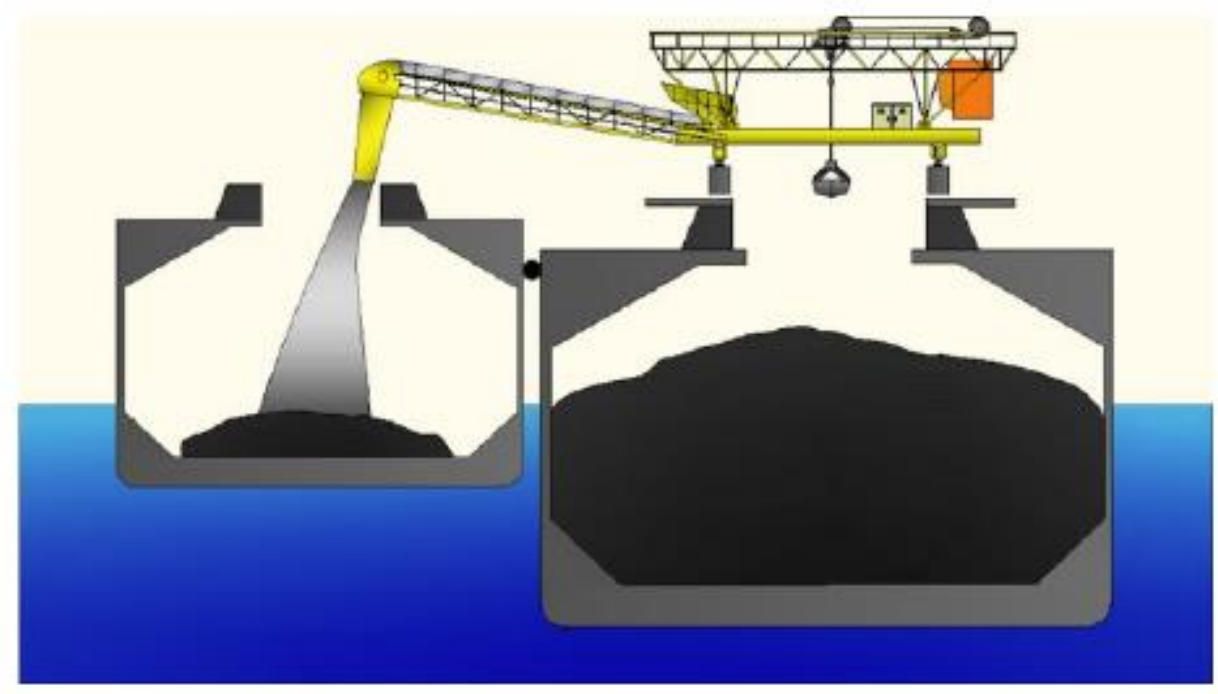

Figura 12 Desenho esquemático do sistema de Cavaletto. Fonte Wang, 2015. 


\section{REVISÃO DA LITERATURA}

Para a confecção deste trabalho, inicialmente, localizaram-se poucas pesquisas relacionadas ao assunto, concluindo-se que o tema ainda é pouco estudado e sendo necessária uma coleta de dados e referências mais detalhada para se chegar a estudos mais completos sobre o tema.

Inicialmente foram pesquisados os termos transbordo e transshipment, porém seus resultados se concentraram principalmente no transbordo simples de carga, sem menção ao transbordo realizado no mar.

Pesquisando o termo transbordo marítimo, foi possível chegar a resultados relacionados ao transbordo de granéis líquidos, principalmente o petróleo, concluindo-se que esse tipo de operação é mais comumente realizada e estudada para os granéis líquidos.

Através da pesquisa de granéis líquidos, chegou-se ao termo ship to ship, também usado como sinônimo de transshipment, onde por meio deste termo foi possível localizar os primeiros artigos internacionais efetivamente relacionados ao tema, porém para granéis sólidos.

Por meio dos artigos internacionais, foi possível localizar referências relacionadas a empresas brasileiras, principalmente as do segmento de minério de ferro, chegando-se então às principais referências bibliográficas que foram usadas como referência neste trabalho e serão explicadas neste capítulo.

O tema de transbordo de carga de navio para navio no mar (transshipment) vem sendo estudado há certo tempo no mundo, porém com mais frequência recentemente devido ao boom dos mega-navios. Os estudos se concentram em diferentes segmentos de cargas, sendo principalmente realizados para granéis líquidos, e recentemente também para sólidos e contêineres (WANG, 2015).

No Brasil, também não foi possível localizar muitas pesquisas científicas sobre o assunto, entretanto, há algumas principalmente relacionadas ao transbordo de granel líquido, especificamente o petróleo.

Já no âmbito das empresas, foi possível identificar que existe interesse em se realizar esse tipo de operação no país, conforme será mostrado em alguns exemplos desse capítulo. 


\subsection{TRANSSHIPMENT PELO MUNDO}

Na década de oitenta, os Estados Unidos da América já pensavam na questão do transshipment para lidar com suas exportações de carvão para a Europa. Buckley, Lee e Kuby (1986) fizeram um modelo de alocação com programação inteira mista que comparava a opção de dragagem com a opção de se fazer o transbordo no mar para reduzir os custos de transporte do carvão e consequentemente o custo final para os mercados europeus. Concluíram que o transbordo era a melhor opção.

Silva et al. (2009) relataram um caso de transshipment no transporte marítimo de carvão oriundo de Moatize (Moçambique). Devido às baixas profundidades do canal de acesso desse porto, o transbordo fez-se necessário no atendimento a navios de grande porte. Neste problema foi utilizada a técnica de simulação de eventos discretos, e o modelo de simulação desenvolvido foi capaz de fornecer diversas respostas do sistema às diferentes configurações propostas.

Cigolini e Rossi (2010) da Escola Politécnica de Milão introduziram uma metodologia para apoiar prestadores de serviços de transbordo no dimensionamento de sistemas para granéis sólidos. Fizeram uma analogia entre o transbordo e os sistemas de produção, usando uma metodologia que se baseia na simulação. $\mathrm{Na}$ Figura 13 os autores mostram o esquema de uma típica operação de transbordo para exportação.

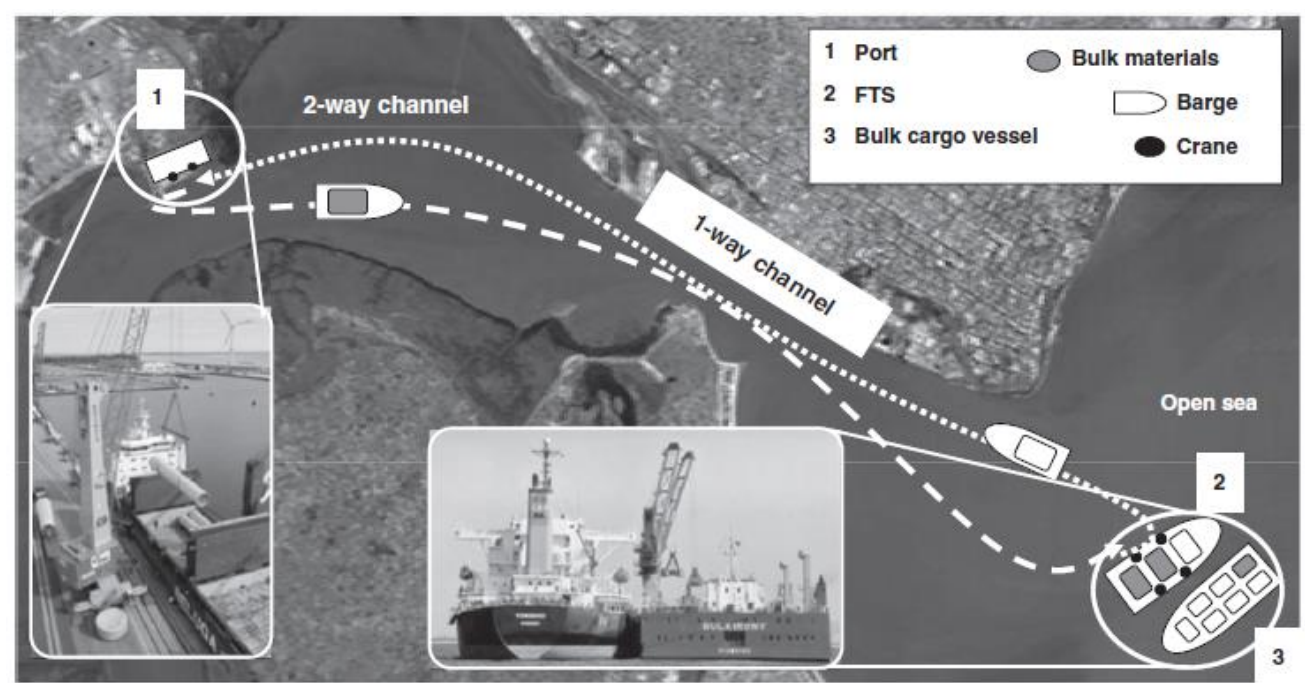

Figura 13 - Esquema de uma típica operação de transbordo usada para exportação. Fonte: Cigolini e Rossi, 2010. 
Em seguida, Cigolini, Pero e Rossi (2011) aplicaram o método que dimensiona um sistema de transbordo para o fornecimento de carvão para uma Usina de energia elétrica na vizinhança de um porto fluvial na Itália. A usina de energia elétrica em estudo previa atender $8 \%$ da eletricidade italiana. As matériasprimas são fornecidas de todo o mundo e transportadas por mar para a planta. Uma vez que os navios não podem navegar no rio (devido à sua profundidade), um sistema de transbordo offshore foi dimensionado por meio de uma simulação, com bons resultados.

Liang, Hwang e Gen (2011) enfatizam que o transbordo navio para navio é usado em portos mais novos, aumentando sua eficiência significativamente, reduzindo o tempo operacional, salvando espaço de armazenagem e reduzindo a carga de trabalho das gruas. Eles apresentaram um modelo matemático em que a função objetivo foi a de minimizar a soma do tempo de manuseio, o tempo de espera dos navios nos berços, o atraso da saída dos navios e a espera para transbordo. $O$ resultado do cálculo demonstrou que, se o intervalo de tempo entre dois navios é bastante pequeno enquanto a quantidade de transbordo é grande, o transbordo direto é melhor, com isso, o tempo de operação pode ser reduzido. Do contrário, a operação convencional passa a ser a melhor opção.

Já Baird e Rother (2012) apresentaram um estudo preliminar técnico e econômico para um terminal flutuante para armazenagem de contêiner e transbordo. Sua função principal seria lidar com cargas de transbordo, porém também poderia apoiar os terminais terrestres dos portos. O artigo lista uma gama de estruturas portuárias flutuantes já em operação e outros conceitos a serem desenvolvidos. O terminal é baseado em um navio convertido, podendo ser alternativa de forma rápida e a baixo custo. Os autores desenham designs possíveis, incluindo configurações de guindastes. Incluem também uma análise de capacidade, produtividade suficiente para garantir um terminal prático comparável a qualquer terminal terrestre. A Figura 14 demonstra uma das configurações do terminal sugeridas pelos autores. 


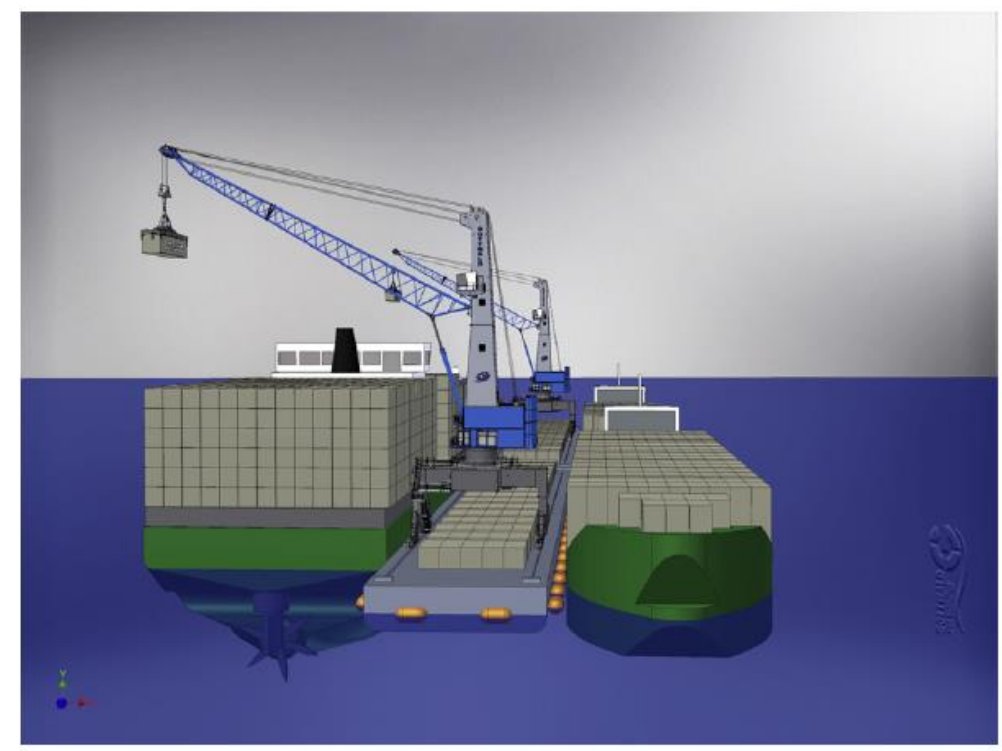

Figura 14 - Configuração de terminal flutuante de transbordo para contêiner. Fonte: Baird e Rother, 2012

Brown (2013) concentrou seu artigo nos detalhamentos de uma operação na Nova Zelândia de exploração do pó de ferro concentrado, suas particularidades, tecnologias e recursos. Em uma das seções detalhou como seria a operação de exportação para o mercado asiático: após a perfuração e captação do pó de ferro (iron sand) este seria alocado em um navio adaptado para armazém da produção e descarregador. O produto então seria transferido para um navio de transbordo que transferiria a um navio do tipo Capesize para ser transportado ao destino final, um porto chinês.

$\mathrm{Na}$ Figura 15 é possível observar um fluxograma operacional para a mineração offshore do pó de ferro e o processamento até o transshipment de exportação. 


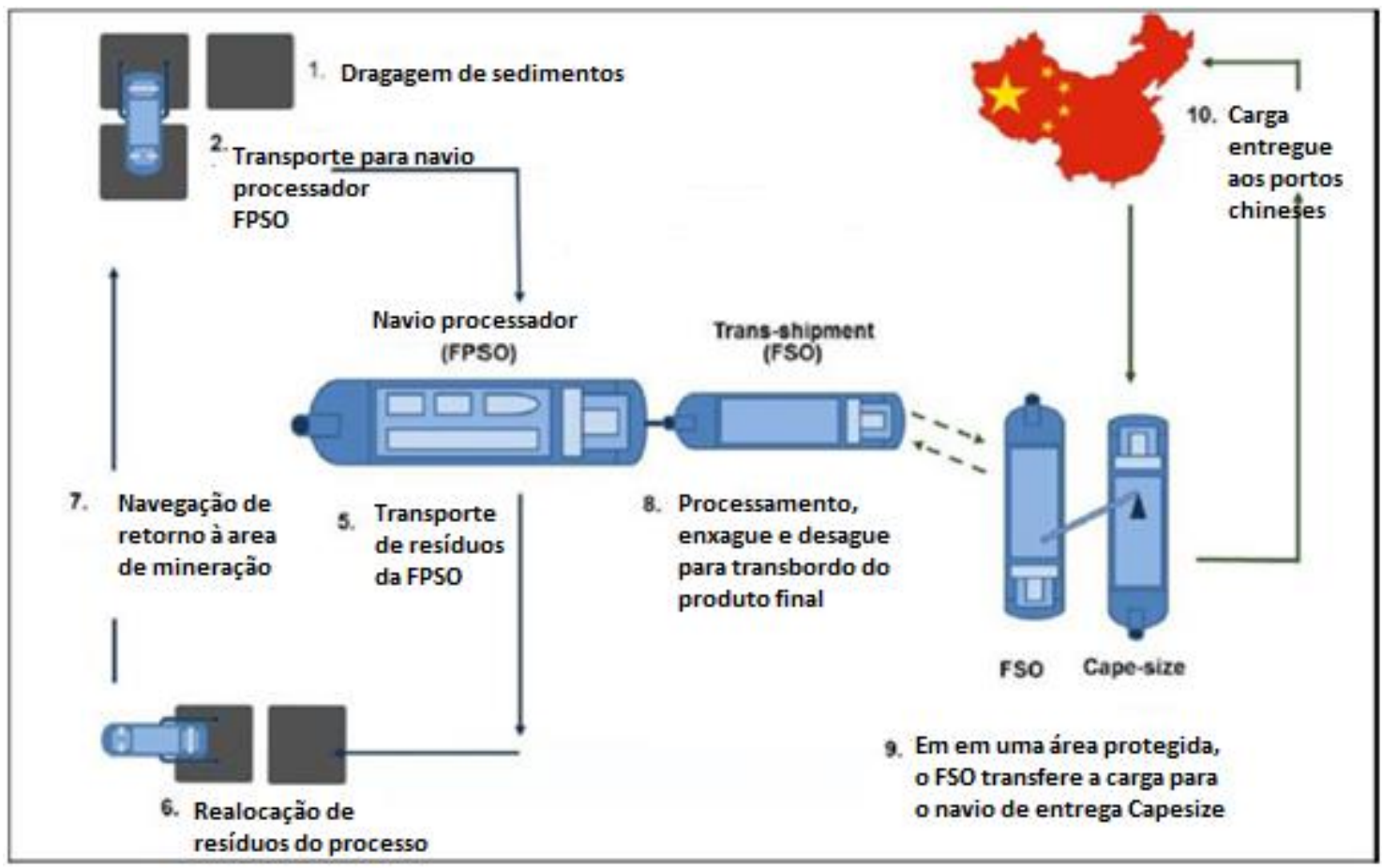

Figura 15 - Fluxograma para mineração do pó de ferro e transshipment para a exportação à China. Fonte: Adaptado de Brown, 2013

Kurt, Boulougouris e Turan (2015) fizeram uma análise de custo de um terminal flutuante de contêiner agindo como um terminal convencional, provendo as funcionalidades básicas para o atendimento de mega-navios. $O$ estudo mostrou que esse tipo de terminal é tecnicamente e financeiramente viável.

Wang (2015) analisou a operação de transshipment para graneis sólidos. Iniciou sua pesquisa detalhando todos os tipos de operação existentes no mundo. Em seguida realizou então um benchmarking das empresas de transbordo. Através de várias configurações de FBTO - floating bulk transshipment operation (operação flutuante de carga geral com transbordo), escolheu o cenário mais representativo: o uso de navio do tipo Capesize com um navio de transbordo - T.U. com grua e navio alimentador. O procedimento de operação e critérios foram descritos com base em entrevistas com diferentes empresas.

Feito isso, a dissertação propôs uma metodologia de avaliação da operacionalidade para o transbordo e para tal realizou uma análise de persistência e dispersão, chegando a um resultado final positivo.

O quadro 1 apresenta um resumo dos estudos localizados durante a pesquisa, resumindo as informações de seus autores, tipo de estudo, ano, método utilizado e conclusão obtida. 
Quadro 1 - Resumo de pesquisas internacionais sobre transshipment.

\begin{tabular}{|c|c|c|c|c|c|}
\hline Autores & Ano & Aplicação & Estudo & Método & Conclusão \\
\hline $\begin{array}{l}\text { Buckley, Lee } \\
\text { e Kuby }\end{array}$ & 1986 & $\begin{array}{l}\text { Estados } \\
\text { Unidos }\end{array}$ & $\begin{array}{l}\text { Exportação de carvão com } \\
\text { transshipment versus } \\
\text { dragagem }\end{array}$ & $\begin{array}{l}\text { Programação } \\
\text { Inteira Mista }\end{array}$ & $\begin{array}{l}\text { Benefício para } \\
\text { Transshipment }\end{array}$ \\
\hline Silva et al & 2009 & Moçambique & $\begin{array}{l}\text { Exportação de carvão pelo } \\
\text { porto de Beira (baixa } \\
\text { profundidade) }\end{array}$ & Simulação & $\begin{array}{l}\text { Benefício para } \\
\text { Transshipment }\end{array}$ \\
\hline $\begin{array}{l}\text { Cigolini, Pero } \\
\text { e Rossi }\end{array}$ & 2011 & Itália & $\begin{array}{l}\text { Dimensionamento de sistema } \\
\text { de transbordo de importação } \\
\text { de carvão para Usina de } \\
\text { energia elétrica }\end{array}$ & Simulação & $\begin{array}{l}\text { Benefício para } \\
\text { Transshipment }\end{array}$ \\
\hline $\begin{array}{l}\text { Liang, } \\
\text { Hwang, Gen }\end{array}$ & 2011 & Geral & $\begin{array}{l}\text { Modelo de decisão pelo } \\
\text { transbordo ou não, usando } \\
\text { variáveis operacionais. }\end{array}$ & $\begin{array}{l}\text { Programação } \\
\text { Linear }\end{array}$ & $\begin{array}{l}\text { Transbordo direto é } \\
\text { melhor se tempo de } \\
\text { espera entre dois } \\
\text { navios é pequena } \\
\text { versus o alto } \\
\text { volume de carga }\end{array}$ \\
\hline $\begin{array}{l}\text { Baird e } \\
\text { Rother }\end{array}$ & 2012 & Geral & $\begin{array}{l}\text { Viabilidade para terminal } \\
\text { flutuante de armazenagem e } \\
\text { transbordo de container }\end{array}$ & $\begin{array}{l}\text { Análise técnica e } \\
\text { econômica }\end{array}$ & $\begin{array}{l}\text { Boa produtividade e } \\
\text { capacidade a menor } \\
\text { custo que terminal } \\
\text { convencional }\end{array}$ \\
\hline Brown & 2013 & $\begin{array}{l}\text { Nova } \\
\text { Zelândia }\end{array}$ & $\begin{array}{l}\text { Exportação de pó de ferro } \\
\text { utilizando transshipment }\end{array}$ & $\begin{array}{l}\text { Pesquisa } \\
\text { Operacional }\end{array}$ & $\begin{array}{l}\text { Benefício para } \\
\text { Transshipment }\end{array}$ \\
\hline $\begin{array}{l}\text { Kurt, } \\
\text { Boulougouris } \\
\text { e Turan } \\
\end{array}$ & 2015 & Geral & $\begin{array}{l}\text { Viabilidade para terminal } \\
\text { flutuante de armazenagem e } \\
\text { transbordo de container }\end{array}$ & $\begin{array}{l}\text { Análise baseada } \\
\text { em custos }\end{array}$ & $\begin{array}{l}\text { Benefício para } \\
\text { Transshipment }\end{array}$ \\
\hline Wang & 2015 & Geral & $\begin{array}{l}\text { Análise de viabilidade } \\
\text { operacional de transbordo de } \\
\text { carga a granel }\end{array}$ & \begin{tabular}{|l|} 
Análise de \\
Persistência e \\
Dispersão \\
\end{tabular} & $\begin{array}{l}\text { Benefício para } \\
\text { Transshipment }\end{array}$ \\
\hline
\end{tabular}

\subsection{TRANSSHIPMENT NO BRASIL}

No Brasil, os trabalhos científicos localizados foram voltados principalmente ao transbordo de graneis líquidos, como petróleo, em alto-mar. O transshipment nas operações de petróleo é antigo e já vastamente usado ao redor do mundo, apesar de somente recentemente ter sido utilizado no Brasil.

O trabalho de Teixeira (2011) apresentou a análise, a partir de um modelo de simulação computacional, do comportamento dos tempos de estadia (tempo de espera dos navios em determinado local) nas operações de transbordo de petróleo nacional, destinado às exportações, realizadas na área de influência do TEBIG Terminal Aquaviário da Baía da llha Grande, no estado do Rio de Janeiro.

O modelo de simulação comparou os tempos de estadia das operações de transbordo, quando apenas realizadas por meio dos berços do terminal TEBIG 
versus a realizada conjuntamente ao transbordo em área de fundeio situada no mar próximo ao terminal e destinada à transferência direta de carga entre embarcações "ship to ship". Observaram-se melhores resultados neste último tipo de operação.

Já Souza (2012) detalhou que os navios petroleiros com posicionamento dinâmico, aqueles capazes de realizar transbordo em movimento, são bastante caros e por isso é desejável aperfeiçoar seu uso eliminando a viagem da plataforma para o terminal de armazenagem. Quando o óleo era destinado à exportação, uma ideia atrativa foi transferi-lo entre o petroleiro e o navio exportador em mar aberto, perto da região de extração. Porém, como os navios exportadores raramente possuem posicionamento dinâmico, é necessário desenvolver uma alternativa para controlar ambos os navios enquanto a operação de transbordo é realizada.

Com isso, o autor propôs duas configurações de transbordo: uma consistindo no arranjo de ambos os navios lado a lado e a outra em comboio, um atrás do outro em movimento. Foram desenvolvidos modelos dinâmicos e analisados por meio de simulação para a comparação dos melhores resultados.

O quadro 2 apresenta um resumo dos estudos localizados durante a pesquisa, resumindo as informações de seus autores, tipo de estudo, ano, método utilizado e conclusão obtida.

Quadro 2 - Resumo de trabalhos nacionais sobre transshipment.

\begin{tabular}{|l|l|l|l|l|l|}
\hline Autores & Ano & Aplicação & \multicolumn{1}{c|}{ Estudo } & Método & \multicolumn{1}{c|}{ Conclusão } \\
\hline Teixeira & 2011 & $\begin{array}{l}\text { Angra dos } \\
\text { Reis - RJ }\end{array}$ & $\begin{array}{l}\text { Comportamento das } \\
\text { estadias dos navios de } \\
\text { petróleo nas operações } \\
\text { convencionais e nas de } \\
\text { transbordo no mar }\end{array}$ & Simulação & $\begin{array}{l}\text { Redução de estadia } \\
\text { no transshipment }\end{array}$ \\
\hline Souza & 2012 & Geral & $\begin{array}{l}\text { Comparativo do } \\
\text { transbordo de petróleo } \\
\text { lado a lado versus o } \\
\text { comboio, devido } \\
\text { posicionamento } \\
\text { dinâmico. }\end{array}$ & $\begin{array}{l}\text { Ambos trazem } \\
\text { benefício, } \\
\text { classificados por } \\
\text { região e maré. }\end{array}$ \\
\hline Silva et al & 2009 & Geral & $\begin{array}{l}\text { Planejamento de } \\
\text { sistema transshipment }\end{array}$ & Simulação & $\begin{array}{l}\text { Senefícios e } \\
\text { detalhamento da } \\
\text { Simulação }\end{array}$ \\
\hline
\end{tabular}




\section{PROJETOS DE EMPRESAS}

Durante as pesquisas localizaram-se estudos de empresas que demonstraram interesse nas operações de transbordo no Brasil. Diante de dificuldades diversas encontradas, que também serão listadas nos capítulos a seguir, algumas empresas buscaram alternativas em países vizinhos.

A Petrobrás possuía o interesse de realizar operações de ship to ship no Brasil. Iniciou suas primeiras operações em 2015 na Bacia de Angra dos Reis-RJ, porém, após alguns vazamentos ocorridos no mar, teve sua licença suspensa. Em seguida estudou o retorno das operações, buscando alternativamente sua realização em algum país da América do Sul.

Já a empresa VALE - uma mineradora multinacional brasileira (2015), uma das maiores empresas de minério de ferro do mundo, diante da necessidade de exportar lotes cada vez maiores de minério ao mercado asiático, concorrendo com países geograficamente mais próximos da Ásia, e consequentemente com fretes mais baratos, como a Austrália, após pesquisas conseguiu desenvolver e fabricar junto a alguns estaleiros o maior navio do mundo, o chamado Valemax, navio com capacidade para transportar cerca de 400 mil toneladas de minério de ferro.

Entretanto, passou a enfrentar resistência para atracar esses navios nos portos chineses, quando surgiu a ideia de criar um FTS - floating transshipment system, um navio-terminal flutuante que opera nos mares das Filipinas realizando transbordo, para então seguir em navios menores aos clientes finais. A Figura 16 demonstra essa operação.

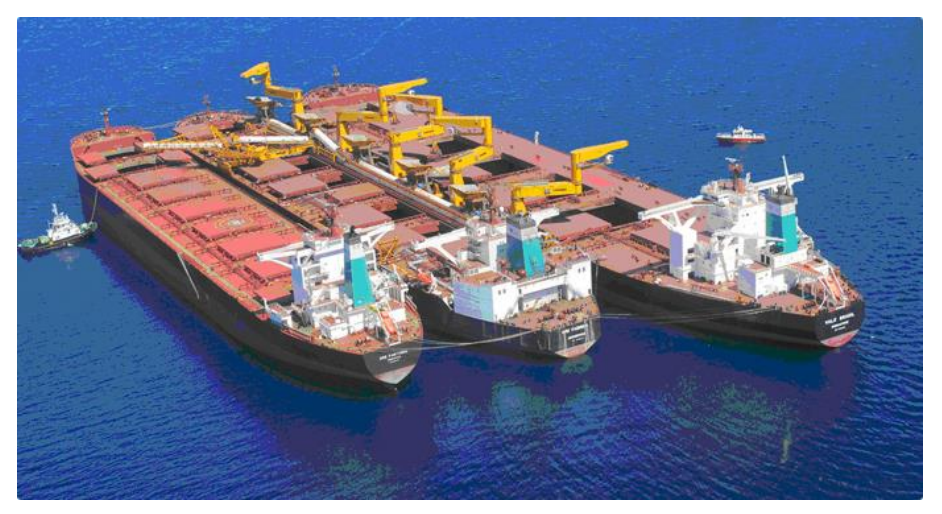

Figura 16 - FTS - floating transshipment system. Fonte: Vale, 2015. 
Esse FTS armazena até 270.000 toneladas de minério e também a possibilidade de realizar uma mistura (chamada de blend) com outros tipos de qualidade de minério para então entregar o produto aos clientes finais asiáticos na composição contratada. A Vale, até este estudo, já havia encomendado uma nova FTS para operar próximo à Coreia do Sul.

A Oldendorff (2016), empresa de transporte e transbordo de carga marítima a granel, relatou que (diante da dificuldade de se realizar a operação de transbordo no Brasil) realiza operações de transbordo de minério de ferro no Caribe, no Golfo de Paria, em Trinidad. O minério é carregado em navios do tipo Handymax em Santana - Amapá onde segue para o Caribe para o transbordo, para destinação final à China e Golfo Árabe.

Sobre a alternativa acima, a empresa Anglo American (2015) buscou por obter a licença para realizar o transbordo no Brasil. O minério iria até a Ponta da Tijoca, um ponto no oceano ao norte do estado do Pará, em barcaças. Lá, guindastes flutuantes transfeririam a carga para navios do tipo Capesize, com capacidade para 150 mil toneladas de minério para exportação. Entretanto, não conseguiram obter as aprovações e optaram por realizar a operação no Caribe.

Já a empresa Vetria buscou como solução logística para o escoamento de produção de uma mina de minério de ferro em Corumbá-MS a opção de exportação pelo Porto de Santos-SP, usando o transshipment. Esse transporte atualmente é realizado por barcaças através da hidrovia Paraná-Paraguai até os Portos da Argentina e do Uruguai, onde é exportado. Porém, a hidrovia possui restrições em sua capacidade uma vez que está sujeita a longos períodos de seca, apresentando problemas com a profundidade ao longo do rio e até mesmo nos portos de destino, onde o tempo de espera às vezes é elevado. Todos estes fatores limitam a capacidade de escoamento de produto desta mina (VETRIA, 2015).

Uma operação de transbordo que já existe em mar aberto brasileiro é a de sal. O terminal salineiro de Areia Branca fica localizado em mar aberto, a $26 \mathrm{~km} \mathrm{da}$ costa do Rio Grande do Norte. A Figura 17 mostra esse Terminal no Rio Grande do Norte (ANTAQ, 2015). 


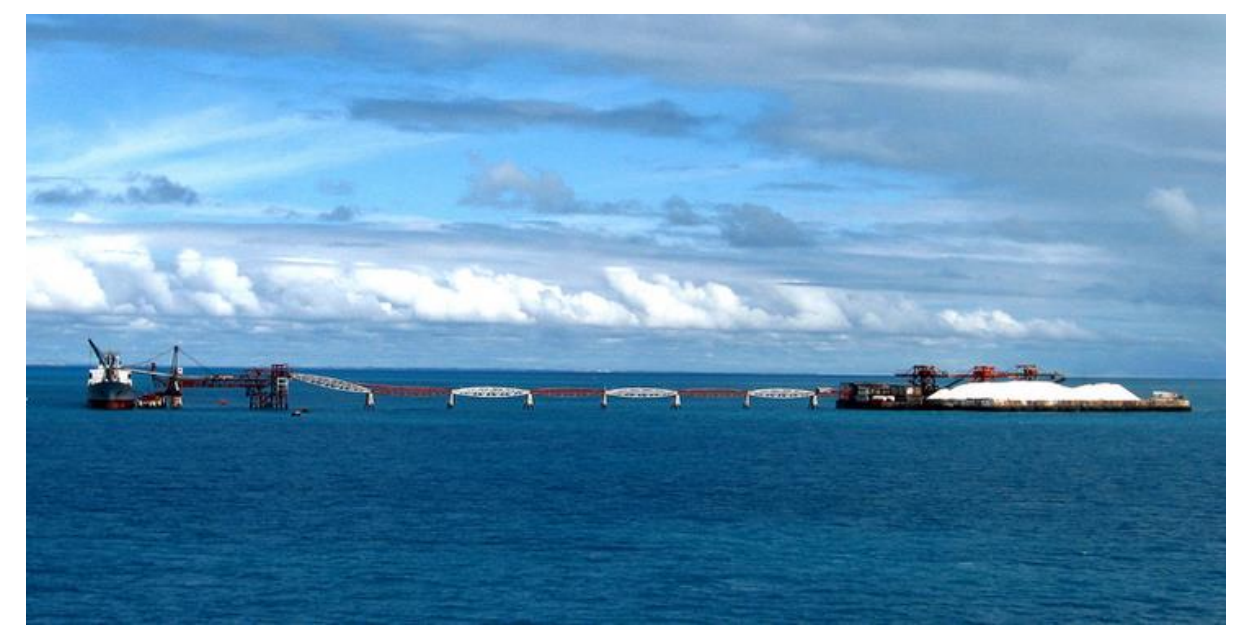

Figura 17 - Terminal Salineiro de Areia Branca - RN. Fonte: Wikipedia, 2015.

O terminal é uma ilha-artificial ${ }^{4}$ que foi construída para que fosse possível transportar o sal produzido no local. O sal das salineiras é transportado através de barcaças até o terminal. Lá é estocado até a chegada do navio transportador. Graças a essa opção o calado chega a $18 \mathrm{~m}$ e os navios conseguem atracar, carregar e seguir viagem ao destino final (ANTAQ, 2015).

\footnotetext{
${ }^{4}$ Ilha que foi formada pelo homem substituindo processos naturais. Geralmente são construídas sobre um recife já existente ou como uma expansão de um ilhéu. Fonte: Wikipedia, 2016.
} 


\section{LEGISLAÇÃO PARA A OPERAÇÃO DE TRANSSHIPMENT}

Durante a pesquisa, observou-se que a legislação pode ser condicionante à realização de uma operação de transshipment.

Para o exterior, foi possível localizar exemplos de países que possuem uma legislação clara relacionada ao tema e com uma aplicação simplificada. No Brasil, entretanto, observou-se que o transbordo é uma operação de difícil definição e interpretação na legislação, já que possui uma classificação genérica e o controle por órgãos diferentes concomitantemente.

A seguir, será apresentado o entendimento legal da operação de transshipment no exterior e no Brasil, bem como os resultados de países encontrados que aplicam legislações diretas para o tema. Serão apontados também os principais orgãos envolvidos nesse tipo de operação.

\section{$5.1 \quad$ NO EXTERIOR}

Nos Estados Unidos, o transbordo ou transshipment, nas definições e termos legais, é classificado como uma transferência de carga de um navio ou meio de transporte para outro para posterior transporte para completar a viagem e levar a carga até o seu destino final. A definição de transbordo pode incluir apenas as transferências por via marítima como uma mudança para outro navio em alto mar ou pode incluir ambas as transferências de navios em hidrovias marítimas e interiores. (US Legal, 2015)

Alerta-se, entretanto, que esse tipo de operação traz dois pontos que devem ser acompanhados: o risco de avaria ou danos na carga, ou a existência de operações ilegais. Tal alerta também como pôde ser observada nas pesquisas relacionadas a outros países que realizam a operação.

No Reino Unido, por exemplo, o conhecimento desse tipo de operação é tão comum que o dicionário de Cambridge classifica diretamente o termo transshipment como a atividade de transporte de mercadorias a partir de um navio para outro (CAMBRIGDE, 2015).

Tal prática é também regulamentada em países como Nova Zelândia, Hong Kong, Singapura, Angola. Em Hong Kong, por exemplo, a referência bibliográfica 
enfatiza a necessidade de se haver um balanço entre o benefício do transshipment e o controle efetivo de suas operações. Neste país, os principais órgãos que regulamentam a operação são a Portaria de Importação e Exportação e o Regulamento de Commodities estratégicas, ambos da Autoridade Marítima de Hong Kong. Eles estabelecem as principais licenças que devem ser obtidas de acordo com o porto onde poderá ser realizada a operação, sendo necessário obter a permissão do orgão ambiental local, da Autoridade aduaneira e da Autoridade marítima (Hong Kong SAR Government, 2015).

\section{$5.2 \quad$ NO BRASIL}

A legislação brasileira versa sobre o transbordo, ainda que de forma tardia se comparada a outros países, porém, não especifica de forma clara as operações de transbordo no mar, como também não as proibe explicitamente.

A figura 18 demonstra um resumo dos principais órgãos envolvidos com esse tipo de operação, como se relacionam e a legislação relacionadas a eles. Em seguida, serão detalhadas neste capítulo as instruções, regulamentações e itens relacionados a este tema para cada uma das autoridades.

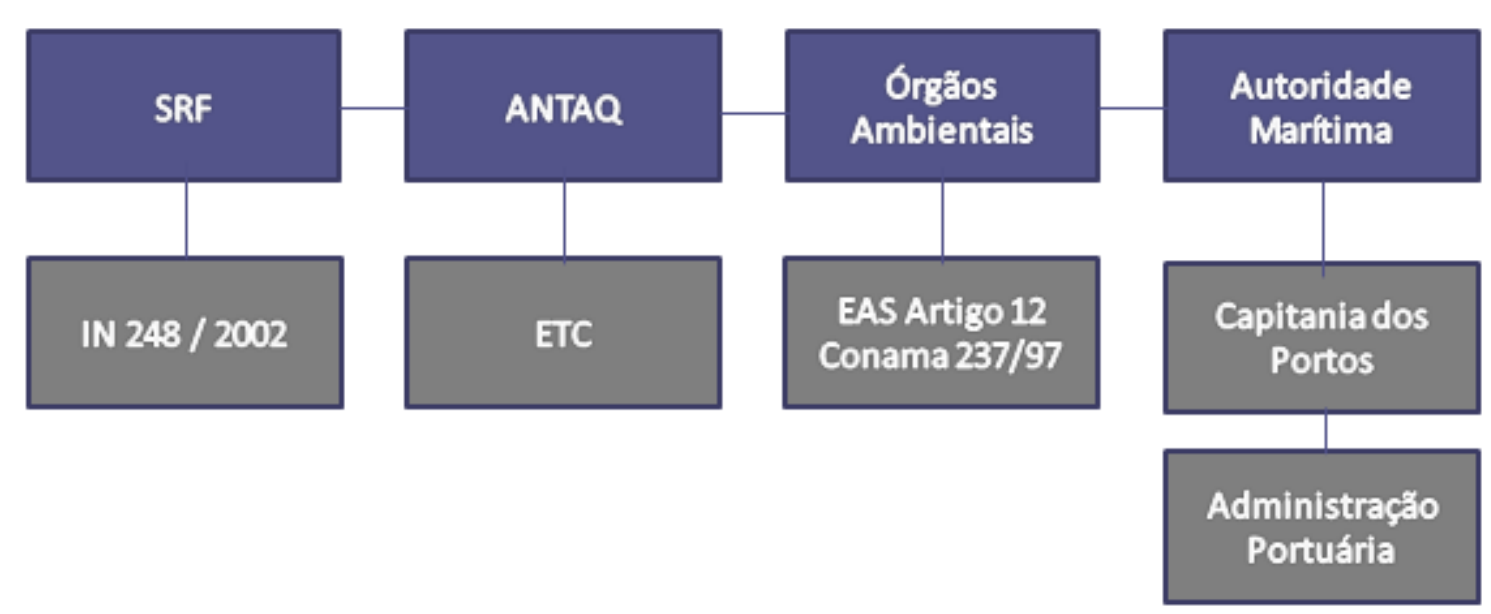

Figura 18 - Resumo dos órgãos e legislação pertinente para o tema de transbordo no Brasil. Fonte: $O$ autor.

\subsubsection{SRF- Secretaria da Receita Federal - Alfandegamento}


A Secretaria da Receita Federal do Brasil - SRF (2015) classifica as operações existentes em três tipos:

1. Transbordo: a transferência direta de mercadorias de um para outro veículo.

2. Baldeação: a transferência de mercadoria descarregada de um veículo e posteriormente carregada em outro.

3. Redestinação: a reexpedição de mercadoria para o destino correto

A IN - Instrução Normativa - IN5 da Secretaria da Receita Federal - SRF no 248, de 2002 detalha que, na carga nacional, o transbordo ou baldeação podem ser realizados no transporte multimodal, onde não se descaracteriza o trânsito aduaneiro.

Já no caso de transbordo ou baldeação de cargas procedentes do exterior e a ele destinadas, o transbordo pode ser realizado, desde que se aplique o Trânsito Aduaneiro de Passagem. Este último é o transporte, pelo território aduaneiro, de mercadoria procedente do exterior e a ele destinada.

Para a Secretaria da Receita Federal (2015), este tipo de operação necessita ser realizada em zona primária, que é a área dos portos, aeroportos e recintos habilitados por ela para operações de carga e descarga. Ainda, sua área pode ser compreendida por um trecho terrestre ou aquático, contínuo ou descontínuo, nos portos alfandegados.

Neste sentido, entende-se que um transbordo no mar poderia ser classificado como uma área aquática para tal fim, sendo necessária uma instalação alfandegada se esta for destinada a carga internacional.

\subsubsection{ANTAQ - Agência Nacional de Transportes Aquaviários}

A Antaq (2016) tornou pública, em 2009, a Resolução de no 1.555/09, aprovando a norma para outorga de autorização para construção, exploração e ampliação de estação de transbordo de cargas.

\footnotetext{
${ }^{5}$ Conjunto das formalidades e informações necessárias para elucidar uma norma, um comportamento ou providências de determinado setor de uma instituição organizacional, elaborado pela Secretaria da Receita Federal do Brasil. Fonte: Secretaria da Receita Federal do Brasil, 2015.
} 
Esta norma tem por finalidade estabelecer critérios e procedimentos para autorização de ETC - Estação de Transbordo de Cargas, é definida conforme segue:

\footnotetext{
Estação de Transbordo de Cargas - ETC: a situada fora da área do porto organizado, utilizada, exclusivamente, para operação de transbordo de cargas destinadas ou provenientes da navegação interior;

Operação de transbordo de cargas: a movimentação de cargas realizada entre distintas embarcações do modal aquaviário ou entre o modal aquaviário e outros modais de transporte; (...)
}

(ANTAQ, 2016)

Esclarece ainda que a navegação interior é a realizada em hidrovias interiores em percurso nacional ou internacional, assim considerados rios, lagos, canais, lagoas, baías, angras, enseadas e áreas marítimas consideradas abrigadas, por embarcações classificadas ou certificadas exclusivamente para esta modalidade de navegação.

A ETC é uma das modalidades de instalação portuária localizada em terra firme - ao longo de hidrovias interiores (rios, lagos, canais, baías, angras, enseadas e de áreas marítimas), ou, no caso das estações flutuantes, situada no próprio mar aberto ou em áreas fluviais ou marítimas consideradas abrigadas. Nesse contexto, entende-se que o transbordo no mar poderia ser classificado como tal.

Entretanto, ela não explicita que poderia ser considerada válida ao transshipment. A iniciativa para regulamentar esta atividade seria importante para auxiliar na melhora dos gargalos que os portos brasileiros vivenciam há décadas.

Antes da vigência dessa Resolução, a atividade de transbordo de cargas estava inserida no sistema normativo ambiental brasileiro por meio da Lei Federal $\mathrm{n}^{-}$ 8.630/93 (Lei dos Portos), em seu artigo 1ํㅗ $\$ 1^{\circ}$, inciso VI, após alteração trazida pela Lei Federal ํㅡ 11.518/07. Porém, como esta alteração foi bastante superficial, somente em termos conceituais, não houve significativas mudanças na prática quanto ao licenciamento de empreendimentos desta natureza (DAZIBAO, 2016).

Este sistema é amplamente utilizado em outros países desenvolvidos (como EUA, Austrália e Europa), e traz alternativa para o escoamento de cargas, sem que seja necessário qualquer construção física de um Porto ou Terminal. Infelizmente a Antaq não deixa clara nesta regulamentação a possibilidade de uma Estação de Transbordo para cargas marítimas (DAZIBAO, 2016). 


\subsection{3 Órgãos Ambientais}

Quanto ao procedimento de licenciamento ambiental, com base na legislação ambiental em vigor, não há uma norma que fale sobre a atividade de transshipment. Assim, pelas características, o órgão ambiental do local poderá exigir estudo menos complexo, como o Estudo Ambiental Simplificado - EAS, estabelecido no artigo 12 da Resolução CONAMA - Conselho Nacional do Meio Ambiente no $237 / 97$.

Este relatório deve conter os estudos dos aspectos ambientais referentes a localização, operação, instalação ou ampliação do empreendimento. Deverá conter, ainda, informações sobre o diagnóstico ambiental da região, bem como a identificação dos impactos ambientais e das medidas de controle, mitigação e compensação (MMA, 2016).

\subsubsection{Autoridade Marítima}

A Autoridade Marítima é função da Capitania dos Portos, que é o representante legal da Marinha.

A Capitania dos Portos exerce atividade estatal e que se destacam pelos procedimentos administrativos das inspeções navais, regras sobre os condutores e demais tripulantes e das regras de segurança no tráfego, o cuidado com a segurança das embarcações, da tripulação, dos passageiros, da carga, das rotas, dos portos e do meio ambiente marinho.

É o ponto de partida da atuação fiscalizadora do Estado (Autoridade Marítima), não só no seu papel legislativo organizador, mas principalmente, na função pública de apuração das infrações à legislação marítima e na atividade de prevenção a acidentes (CODESP, 2015).

Durante a pesquisa não foi possível localizar alguma norma desta que mencionasse a operação de transbordo, porém, neste aspecto, sugere-se que a Autoridade Marítima local seja consultada a cerca das regras e autorização para a realização de transshipment no porto desejado. 


\section{APLICAÇÃO AO CASO DO PORTO DE SANTOS-SP}

Para a análise de viabilidade operacional e de custos da operação de transshipment no Brasil, foi escolhido o Porto de Santos pois, conforme mencionado anteriormente, é o principal do país e possui restrição a determinados tipos de navios.

A operação a ser simulada será a de minério de ferro para exportação, devido a esse tipo de carga demandar navios grandes, já que seus lotes de pedidos são grandes, como será explicado neste capítulo. Foi escolhida a mina produtora localizada em Corumbá-MS para atendimento ,já que esta não possui uma solução logística ideal e o estado do Mato Grosso do Sul estar em região de influência do Porto de Santos, como será apresentado a seguir.

\subsection{O PORTO DE SANTOS}

O Porto de Santos-SP, é o principal do país e um dos mais movimentados na América Latina. Sua área de influência concentra mais de 50\% do Produto Interno Bruto - PIB do país, tendo como principais estados atendidos São Paulo, Minas Gerais, Goiás, Mato Grosso e Mato Grosso do Sul (CODESP,2015).

Seu calado máximo operacional é de 13,20 metros (CODESP, 2015), o que ainda é insuficiente para as embarcações maiores que estão surgindo.

Nos períodos de picos de movimentação, o Porto de Santos enfrenta filas para atracação, gerando falta de berços suficientes para operar os navios que aguardam na região da barra (PORTOS E NAVIOS, 2016).

Como principal porto do país, é servido por diversas linhas marítimas e diferentes Armadores, proporcionando, por vezes, as melhores tarifas para operação. Mesmo com o surgimento e influência de novos portos no país, Santos tem mantido seu protagonismo.

Diante de sua importância para a logística portuária nacional, é necessário se pensar em soluções criativas para prepará-lo para receber navios maiores, que conforme verificado anteriormente neste trabalho, são tendência na área naval e marítima. 


\subsection{O MINÉRIO DE FERRO DE CORUMBÁ-MS}

O minério de ferro produzido no Brasil destina-se principalmente ao mercado externo, assumindo um papel relevante no comércio mundial, como será exposto em seguida.

O Brasil é um dos maiores produtores mundiais de minério de ferro e sua produção se realiza em minas a céu aberto, possuindo a segunda maior reserva de minério do mundo e sendo o produto mais exportado em portos pelo país em termos de tonelagem (IBRAM,2015).

A produção do Brasil está em sua maioria dedicada ao ferro gusa, em usinas siderúrgicas integradas e produtores independentes, bem como a produção das pelotas. Já para a exportação, o minério de ferro predomina entre os minerais exportados para o mercado internacional. O consumo externo de bens primários de ferro atingiu, em 2011, perto de 330 milhões de toneladas, ou seja, cerca de $85 \%$ da produção total é destinada ao exterior (IBRAM,2015).

As regiões mais conhecidas de produção são o Quadrilátero Ferrífero - MG, a Província Mineral de Carajás - PA e a região de Corumbá-MS. Novas fronteiras de produção também estão surgindo na Bahia e em Piauí.

Os lotes de pedidos de minério de ferro para exportação usualmente são grandes em volumetria com pedidos concentrados, naturalmente sendo melhor atendidos por navios grandes.

\subsection{A LOGÍSTICA ATUAL DO MINÉRIO}

O Mato Grosso do Sul enfrenta desigualdade logística em relação aos demais centros produtores de minério, o que passa a ser um obstáculo para a exploração e desenvolvimentos das minas desse Estado e constitui um desafio grande (BNDES, 2015).

O transporte do minério de ferro produzido em Corumbá/MS atualmente é realizado por barcaças através da hidrovia Paraná-Paraguai até os Portos da Argentina e do Uruguai, onde é exportado (VETRIA, 2015).

A hidrovia possui restrições em sua capacidade uma vez que está sujeita a longos períodos de seca, apresenta problemas com a profundidade ao longo do rio e 
há restrições até mesmo nos portos de destino, onde o tempo de espera às vezes é elevado. Todos estes fatores limitam a capacidade de produção e escoamento das minas existentes lá (VETRIA, 2015).

Além disso, a hidrovia possui expansão limitada em virtude de falta investimentos não realizados, tem baixa confiabilidade devido a questões ambientais, como o traçado natural que impede maior velocidade das barcaças, e principalmente a restrição de chuvas, durante períodos de seca. (VETRIA,2015).

No transporte marítimo, grande parte do minério do país produzido em Minas Gerais e no Pará é escoado por TUPs - terminais de uso privativo, e possuem solução logística específica, desenhada pelas empresas produtoras, que são multinacionais detentoras do controle de boa parte da cadeia do minério. A mina de Corumbá-MS, entretanto, é a única que não possui uma solução portuária própria (BNDES,2015).

Segundo o BNDES - Banco Nacional de Desenvolvimento Econômico e Social (2015), as minas localizadas na Região Centro-Oeste são as que apresentam maior desafio logístico para exportação. A restrição logística (leia-se disponibilidade de malha ferroviária e, principalmente, portos com capacidade suficiente para escoamento da produção) torna-se o maior entrave ao aumento de produção e escoamento de Corumbá-MS.

Ainda, a mina de Corumbá-MS possui capacidade de dobrar sua produção, porém, os portos atuais que exportam essa carga possuem terminais com restrição de aumento de capacidade e sem interesse formal de expansão quando consultados (VETRIA,2015).

\subsection{UMA PROPOSTA LOGÍSTICA}

Este item apresenta um resumo de uma proposta logística de escoamento de minério para as minas de Corumbá-MS. Esta opção, conforme citada anteriormente, foi estudada pela Vetria (2015) e o que será apresentado a seguir como opção logística até a chegada ao Porto de Santos-SP é uma das alternativas que foi estudada por essa empresa.

Entretato, o problema que se apresenta posteriormente e sobre o qual não se estudaram possíveis soluções ainda, é como o minério poderá ser exportado por 
via marítima em Santos-SP na melhor configuração operacional e financeira, o que será o foco deste trabalho.

Desta forma, os itens a seguir apresentarão de forma sucinta a operação ferroviária e a localização do TUP em Santos-SP, seguidos de um enfoque à operação portuária, que consecutivamente será analisada detalhadamente através dos capítulos 7 e 8 , dedicados a analisar operacionalmente e economicamente a operação marítima.

Nesta proposta, o minério de ferro do Mato Grosso do Sul seria transportado via ferrovia até o porto de Santos em um novo TUP. A Figura 19 demonstra a opção logística atual e a nova.

As minas de Corumbá apresentam capacidade para aumentar sua produção para aproximadamente 20 milhões de t/ano, e hoje produzem cerca de 10 milhões.

A região do Maciço do Urucum fica muito próxima a uma ferrovia já existente. Essa ferrovia liga ao Porto de Santos e possui $1.765 \mathrm{~km}$ de extensão, contra $2.700 \mathrm{~km}$ da hidrovia. Essa linha férrea é possível de ser adaptada ao transporte de minério, mas necessitará de investimentos. Chegando ao Porto de Santos, sabe-se que a Antaq já emitiu licença prévia para Terminal de Uso Privativo que poderia ser usado para a movimentação de minério (VETRIA, 2015).

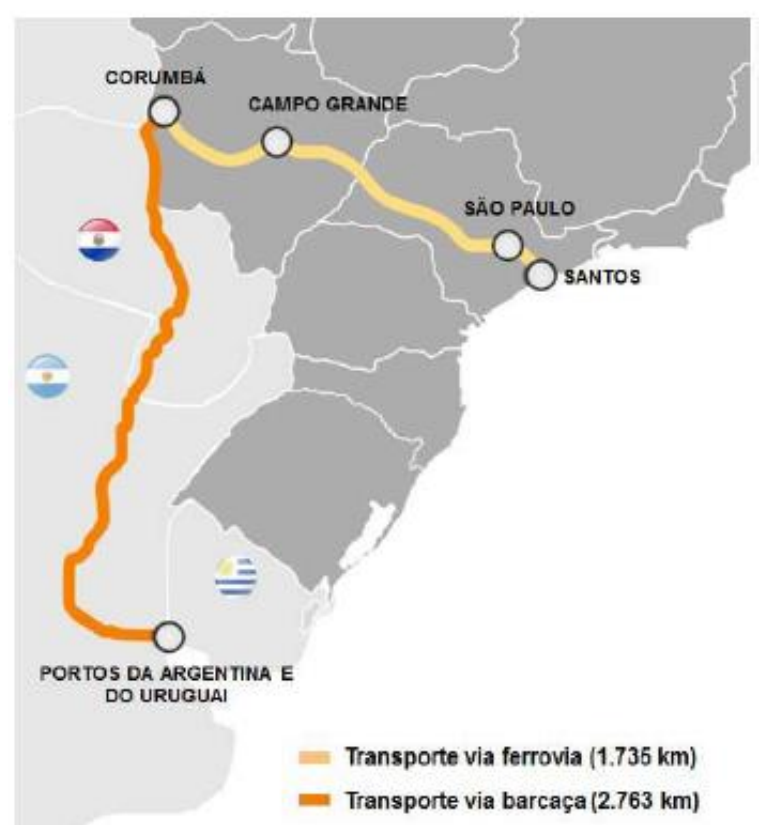

Figura 19 - Logística atual e proposta para as minas de Corumbá-MS, Fonte: Vetria, 2015. 


\subsubsection{Ferrovia}

O percurso da linha férrea que liga Corumbá a Santos percorre os estados do Mato Grosso do Sul e de São Paulo, e possui três principais divisões de malhas ferroviárias, sendo: Malha Oeste, Malha Paulista e Acesso ao Porto de Santos (VETRIA, 2015).

Pelas más condições devido a falta de manutenção, a capacidade de transporte desta via é limitada, necessitando de intervenções e investimentos para atender a demanda desejada (VETRIA, 2015).

Seria necessário investimento em modernizações do trecho, como: substituição de trilhos, dormentes, construção de pátios e adequação de infraestrutura, ampliação de capacidade de peso e volumetria, eficiência, segurança e velocidade da ferrovia (VETRIA, 2015).

Esclarece-se, ainda, que este trecho de ferrovia realiza transporte de cargas que não o minério, e que, para que pudesse transportá-lo, haveria competição de produtos pela mesma capacidade de vagões. A ferrovia possui uma capacidade máxima que já está ocupada com outros produtos, o que poderia inviabilizar o transporte do minério nesta condição. Tal decisão dependeria de qual produto teria prioriade de transporte, tendo que ser definida pelas empresas envolvidas juntamente aos órgãos competentes do governo (VETRIA, 2015).

Entretanto, como este trabalho tem como objetivo a análise da operação marítima em si, esta restrição não inviabiliza a realização e continuidade do estudo do transshipment.

\subsubsection{O TUP - Terminal de Uso Privativo}

Na parte continental do Largo Santa Rita-SP, servida pelo canal do Porto de Santos, encontra-se o local onde pode ser desenvolvido o TUP para minérios. A Figura 20 destaca a área expandida do local. 


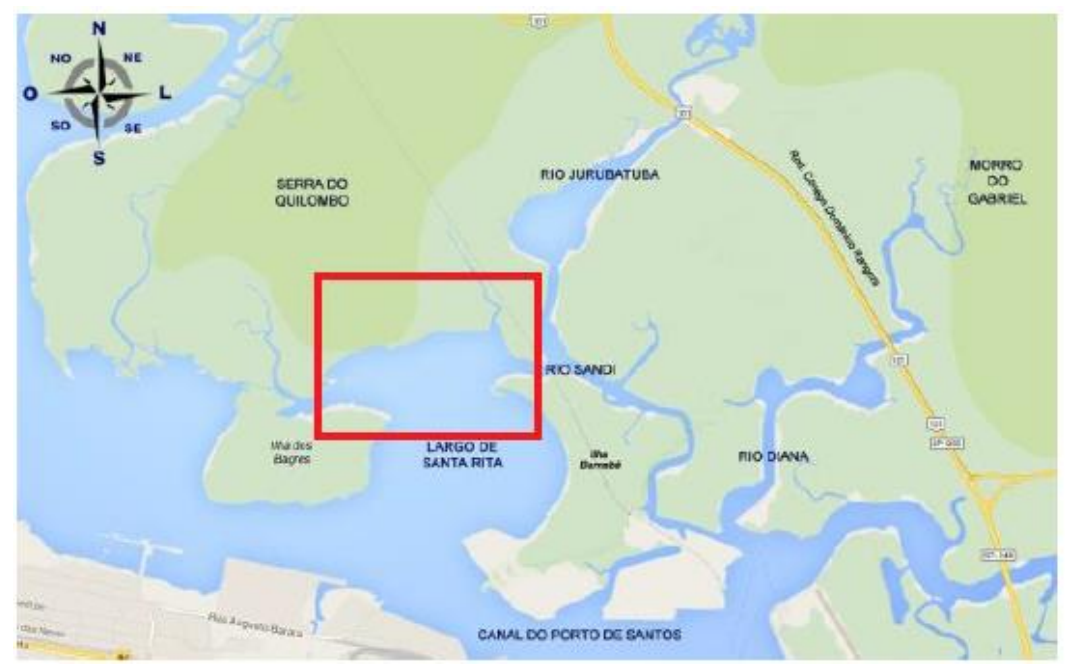

Figura 20 Largo de Santa Rita, entre as ilhas de Bagre e Barnabé. Fonte: Google Maps

Esta área já obteve a Licença Prévia da Antaq para se construir um TUP, que poderia ser dedicado a operação de commoditites, entre elas o minério (VETRIA, 2015).

A decisão de se utilizar esse TUP para o minério depende de decisões de entidades envolvidas, como empresas e orgãos governamentais. Logo, sua aplicação depende de decisões terceiras e da definição do que é prioridade para o porto e para o país no momento de sua aplicação.

Todavia, o porto de Santos-SP já possui outros terminais que operam o minério de ferro e poderiam ser utilizados para escoar esse produto, a depender de negociação de valores e de capacidade de movimentação do terminal para sua realização.

\subsubsection{A operação portuária}

Partindo-se da premissa de que a carga chegaria ao TUP no porto de Santos-SP para ser exportada, a dissertação pretende analisar a operação convencional de exportação e a viabilidade de se fazer o transbordo da carga em região próxima ao porto, visando ganhos de escala decorrentes da utilização de navios maiores.

Como visto no tópico dedicado a projetos de empresas deste trabalho, o transshipment se aplica a casos similares dedicados a operações de minério de 
ferro, despertando assim o interesse da autora em aplicar tal solução a este caso em análise.

Ainda, como apresentado anteriormente, o minério demanda mega-navios já que, devido às características da carga, gera lotes de pedidos grandes e concentrados, podendo ter seu transporte otimizado em navios maiores, sempre que possível.

Assim sendo, a autora selecionou para análise a operação de transbordo de carga de navio para navio no mar, em região na barra do porto de Santos-SP. Pretendeu-se com isso analisar a operação e seus custos decorrentes.

Para se checar a viabilidade da operação, foram avaliados os métodos existentes para tal e escolhida a simulação para aplicação, como será explicado no Capítulo 7. Para a análise de custos, serão utilizados dados como o frete, o aluguel do navio, a despesa de combustível, as despesas portuárias, o demurrage (custo de estadia do navio) . Estes custos serão detalhados no capítulo 8. 


\section{ANÁLISE OPERACIONAL DE UM SISTEMA DE TRANSSHIPMENT}

Para se avaliar o problema do transshipment, inicialmente foram estudadas as alternativas de decisão que poderiam ser aplicadas a ele de forma a se obter os resultados esperados.

Em seguida, foram confeccionados os modelos conceituais do processo convencional de operação de exportação de minério e o de transshipment no porto de Santos-SP. A partir deles, dada as características do problema, foi selecionado o modelo de simulação computacional para a realização da análise e obtenção dos resultados.

Este capítulo apresenta o passo a passo desta elaboração, que passa pela definição do problema a ser analisado, a análise de decisão realizada, os parâmetros e cenários utilizados, as simulações e os resultados obtidos.

\subsection{ALTERNATIVAS DE DECISÃO}

$\mathrm{Na}$ análise de alternativas, a P.O. - Pesquisa operacional., se apresenta como um método científico que auxilia a tomada de decisões. A P.O. é um sistema organizado de auxílio de modelos, bem como de experimentação, com o intuito de operar um sistema da melhor maneira possível (WINSTON, 1994).

Dentre os principais tópicos que a Pesquisa Operacional aborda estão: a Programação Matemática, as Árvores de Decisão, a Teoria das Filas e a Simulação (WINSTON, 1994).

A Programação Matemática visa a otimização de resultados. Nela é feita uma modelagem matemática de um determinado problema para que, por meio de algoritmos, seja encontrada a solução ótima (WINSTON, 1994).

As Árvores de Decisão são utilizadas na representação de modelos reais. Pode-se utilizá-las para representar, por exemplo, estradas e utilizar algoritmos para se determinar o caminho mais curto (WINSTON, 1994).

$\mathrm{Na}$ Teoria das Filas, estuda-se o comportamento das filas em espera. Tratase de um modelo probabilístico que não possui o objetivo de encontrar uma solução ótima para o problema e sim analisar a probabilidade de um evento ocorrer (WINSTON, 1994). 
Já a Simulação consiste em criar modelos representativos de um processo ou sistema do mundo real. O modelo de simulação estuda o comportamento do sistema que é analisado por meio de relações entre as entidades (objetos de interesse) dele. Uma vez validado, o modelo permite fazer questões sobre o funcionamento do sistema. A simulação também pode ser utilizada durante a fase de projeto, ou seja, antes do sistema ser construído, já que lida com incertezas. Ela, portanto, é uma ferramenta que permite analisar o efeito de mudanças em sistemas já existentes, e também prever a performance de novos sistemas em diferentes circunstâncias (BOTTER, 2002).

Optou-se pelo método de Simulação para realizar esta análise, dado que há a necessidade de se estudar uma operação já existente, testar seu comportamento e diferentes interações com os objetos relacionados, bem como uma nova operação com a utilização de transbordo, que possui grau de incerteza por não ter sido realizada antes no Brasil.

Para o desenvolvimento do modelo de Simulação, a metodologia utilizada foi baseada nos passos propostos por Botter (2002), que são basicamente compostos por:
a) Definição do Problema
b) Planejamento da Proposta
c) Definição do Sistema
d) Formulação Conceitual do Modelo
e) Projeto preliminar do experimento
f) Preparação dos dados de entrada
g) Codificação do modelo;
h) Verificação e validação do modelo;
i) Projeto final do experimento;
j) Experimentação e análises de sensibilidades;
k) Análise e interpretação dos resultados;

Os itens (a) a (c) foram analisados nos tópicos anteriores, durante a definição do problema e o planejamento da proposta de análise contida nos 
modelos conceituais. Os demais itens seguem na sequência, conforme propõe a metodologia.

\subsection{MODELO CONCEITUAL DO SISTEMA DE TRANSSHIPMENT}

Conforme identificado anteriormente, o calado operacional máximo atual do Porto de Santos é de 13,20 metros. Desta forma, realizando-se uma operação portuária convencional, o maior navio que poderia atracar em um terminal em Santos seria o da classe Panamax, conforme mostra a tabela 1, que apresenta as principais classes de navios graneleiros.

Tabela 1 - Tipos/Classes de navios graneleiros e suas respectivas dimensões

\begin{tabular}{ccccc} 
CLASSE & PORTE (dwt) & $\begin{array}{c}\text { COMPRIMENTO } \\
\text { TOTAL MÉDIO }(\mathrm{m})\end{array}$ & $\begin{array}{c}\text { BOCA } \\
\text { MÉDIA }(\mathrm{m})\end{array}$ & $\begin{array}{c}\text { CALADO MÁXIMO } \\
\text { MÉDIO }(\mathrm{m})\end{array}$ \\
\hline Handymax & $30 \sim 55.000$ & 175,0 & 28,0 & 10,5 \\
\hline Panamax & $60 \sim 80.000$ & 227,0 & 32,2 & 12,3 \\
Capesize & $80 \sim 250.000$ & 252,0 & 41,0 & 14,6 \\
\hline $\begin{array}{c}\text { Very Large Bulk } \\
\text { Carrier - VLBC }\end{array}$ & $250 \sim 400.000$ & 309,5 & 54,0 & 18,6 \\
Valemax & $\begin{array}{c}\text { Acima de } \\
400.000\end{array}$ & 365,0 & 66,0 & 23,0
\end{tabular}

Fonte: Adaptado de Magalhães (2007).

Esta análise não considerou os navios com carregamento parcial, também chamados de navios aliviados, pois foi utilizada como premissa o carregamento dos navios utilizando o calado médio, de forma a carregar os navios conforme seus portes de carga padrão.

BANKs et al (2005) explica que um modelo é uma representação que visa a avaliação de um sistema, seu comportamento e alterações em função de variáveis e parâmetros envolvidos.

Os modelos podem ser de diferentes tipos, como: físico e matemático, para modelos estáticos ou dinâmicos, podendo ser subdivididos ainda em modelos numéricos e analíticos (BANKS ET AL, 2005). 
O modelo conceitual é um diagrama que demonstra as relações das entidades, seus atributos, suas relações e especializações. Através dele é possível apresentar o sistema e prepará-lo para experimentos (CHWIF E MEDINA, 2007).

Neste contexto, realizando-se uma operação convencional de minério no porto de Santos-SP, o processo ocorreria da seguinte forma:

O navio da classe Panamax chegaria ao Porto de Santos, aguardaria a permissão de entrada na barra e, uma vez que houver berço disponível, o navio seguiria para o terminal, atracaria, carregaria o minério e aguardaria no Terminal. Se o canal estivesse disponível, desatracaria e seguiria viagem. A figura 21 demonstra o modelo conceitual de uma operação convencional, utilizando Panamax.

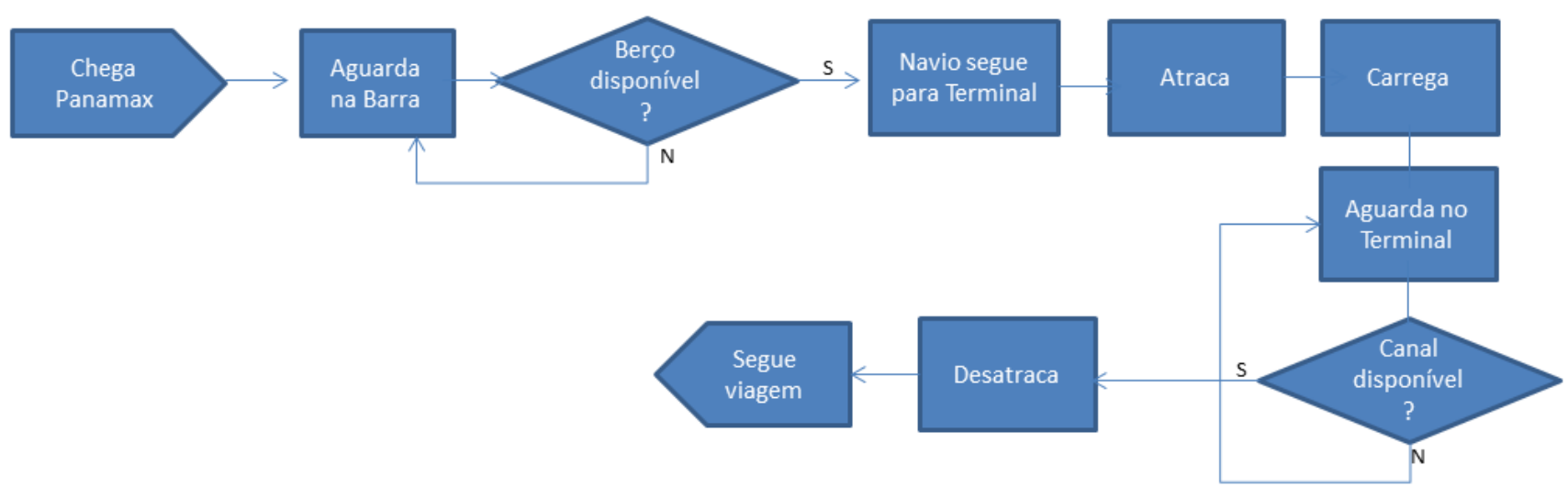

Figura 21 Modelo conceitual da operação convencional com uso de Panamax.

Já na região da barra do Porto de Santos, poderiam ser utilizados navios maiores como os da classe do Capesize, por exemplo, dada a profundidade do local.

Desta forma, uma opção seria realizar o transshipment através de um navio T.U. da classe Handymax, como visto anteriormente, carregando a mercadoria no terminal portuário e levando ao navio maior ancorado na barra do porto de Santos.

Este navio Handymax carregador T.U. chegaria ao porto, aguardaria disponibilidade de berço na barra e, uma vez disponível, seguiria para o terminal, atracaria e carregaria o minério. Uma vez que o canal estivesse disponível, ele desatracaria e seguiria para a barra, atracaria na barra e descarregaria a carga no Capesize. Caso houvesse mais carga a ser carregada, faria novamente o processo, do contrário, seguiria para a ancoragem. A figura 22 demonstra o modelo conceitual da operação do navio carregador Handymax T.U. 


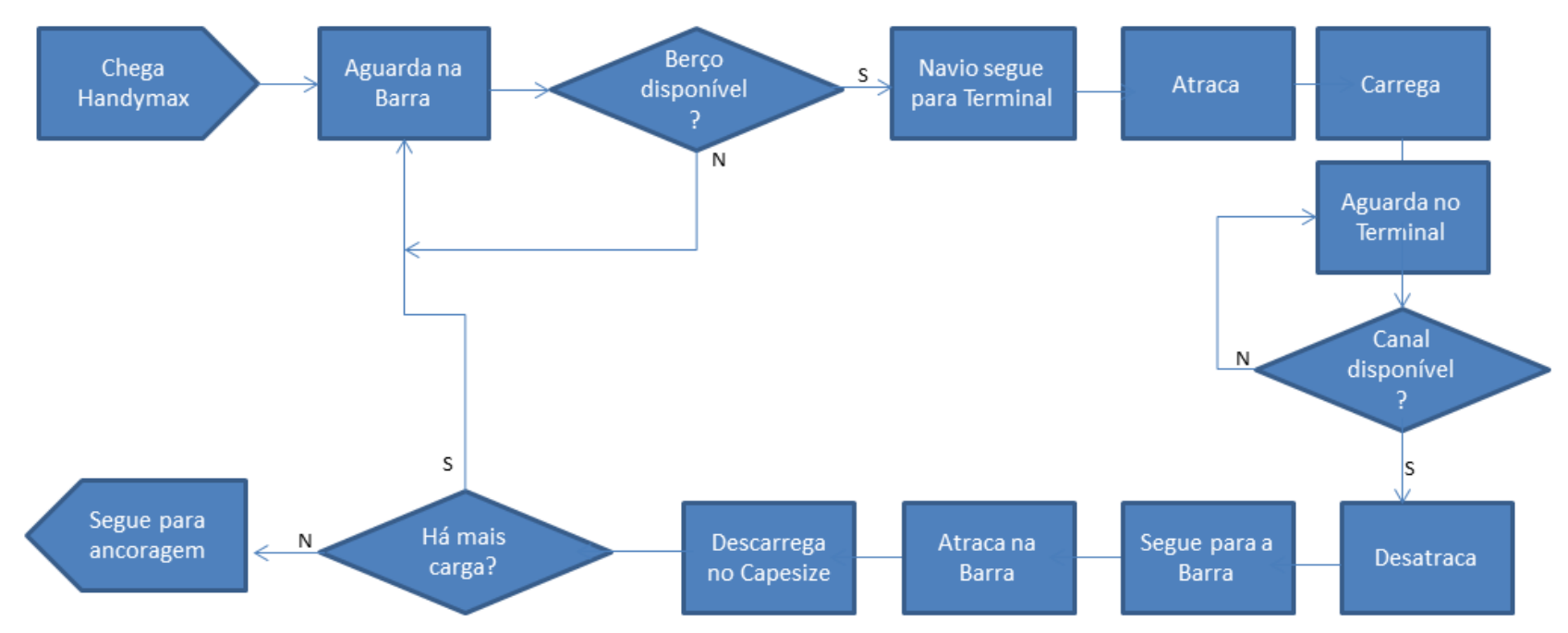

Figura 22 Modelo conceitual da operação do navio carregador/T.U. Handymax.

Já o navio maior, o Capesize, ficaria ancorado na barra em Santos aguardando o T.U. Handymax carregar e trazer a carga até ele, seguindo viagem ao destino final quando estivesse totalmente carregado.

Com isso, seu processo teria os seguintes passos: o navio Capesize chegaria a Santos, aguardaria na barra e, uma vez que o local de ancoragem e transshipment estivesse vazio, ele atracaria em um quadro de boias, receberia o carregamento, desatracaria e seguiria viagem ao destino final.

A figura 23 apresenta o modelo conceitual da operação do navio Capesize OGV (Ocean Going Vessel), ou seja, aquele que seguirá viagem ao destino final.

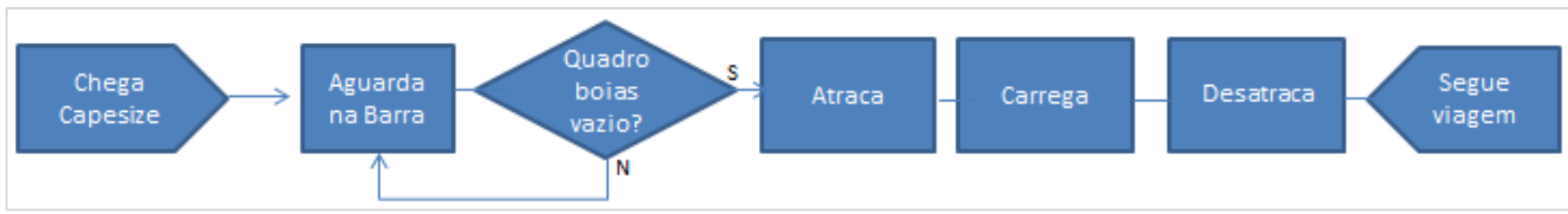

Figura 23 Modelo conceitual da operação do navio Capesize OGV.

Por fim, quanto a capacidade de produção da mina do Maciço de Urucum em Corumbá-MS, fo visto anteriormente que ela produz aproximadamente 10 milhões de t/ano de minério, com capacidade de expansão.

Desta forma, uma premissa considerada é que o sistema de transshipment deve ser capaz de atender a essa demanda. 


\subsection{CENÁRIOS E PARÂMETROS ANALISADOS}

Neste momento, junto aos passos definidos por Botter (2002), serão considerados também Chwif e Medina (2007), que dividem a definição do sistema e a elaboração do modelo de Simulação em três etapas:

a) Concepção: definição do sistema, objetivos, levantamento de dados e modelagem conceitual;

b) Implementação: elaboração do modelo computacional, sua verificação e validação;

c) Análise: realização de simulações desejadas, análise de sensibilidade e análise de resultados.

A figura 24 demonstra em ordem cronológica esse passo a passo para o desenvolvimento do modelo de simulação.

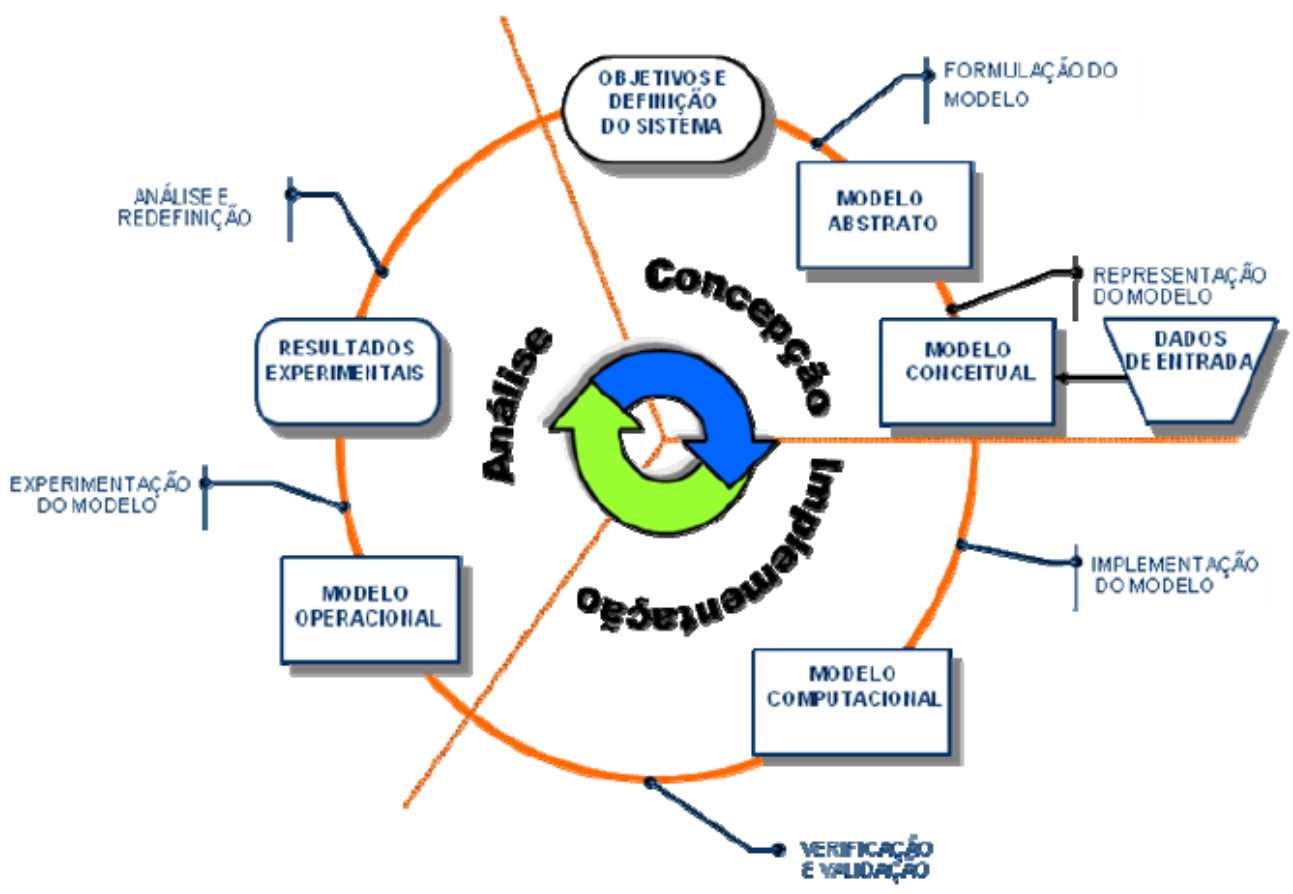

Figura 24 - Metodologia de desenvolvimento do modelo de simulação. Chwif e Medina, 2007.

Em seguida, identicados os modelos, foram definidos os cenários de análise e avaliação do sistema. Para isso, foram inicialmente simulados dois cenários de configuração de operação, sendo: 
- Cenário A: Operação convencional direta via terminal portuário, utilizando navios da classe Panamax.

- Cenário B: Operação com transshipment usando 1 navio da classe Handymax como alimentador e 1 navio da classe Capesize como principal fundeado em mar aberto em Santos.

Ao final, o cenário convencional (A) foi comparado ao cenário (B) para que fosse identificada a configuração mais adequada para a operação.

Adicionalmente, definiram-se os processos que os cenários devem apresentar, com os seguintes objetivos:

- Representar a operação de transshipment de minério de ferro pelo Porto de Santos, carregando um navio alimentador Handymax no terminal portuário e levando a carga até o navio principal, fundeado em um quadro de bóias a cerca de $30 \mathrm{~km}$ do porto, em ciclo fechado.

- Dimensionar a frota de navios necessários para escoar a demanda do minério de ferro nos dois cenários.

- Realizar análise de sensibilidade para condições operacional e climáticas adversas que podem atrasar ou suspender as operações de transshipment.

- Comparar a operação de transbordo com a operação convencional.

Para incorporar ao modelo, os seguintes parâmetros abaixo foram considerados, com base em Silva et al. (2009):

- Taxas de produtividade de carregamento no Terminal e na descarga do transbordo.

- Tempo de atracação e desatracação.

- Tempo de viagem entre o Terminal e a região onde será realizado o transshipment.

- Tempo de espera por condições operacionais e climáticas adversas.

- Tempo de limpeza dos porões da embarcação alimentadora (ou T.U.). 
Parar dar continuidade à análise operacional, o próximo passo foi levantar todos os valores utilizados como parâmetros de entrada dos modelos.

\subsection{IMPLEMENTAÇÃO COMPUTACIONAL}

Definidos os dados de entrada, o modelo conceitual, os objetivos e a definição do sistema, passou-se à fase de implementação, onde foi elaborado o modelo computacional e feita sua verificação e validação, ou seja, o sistema foi testado e depurado de forma informatizada.

Dado que o sistema de transshipment é dinâmico e complexo por possuir fatores não controlados e com inúmeras variáveis que interagem entre si, foi escolhido o uso da Simulação Computacional como ferramenta para uma melhor análise.

Para a execução via sistema, foi utilizado o software Arena. No Arena, a modelagem é feita visualmente por meio de objetos orientados à simulação, que são transformados em comandos de lógica, podendo ser testados inúmeras vezes em busca de resultados (CHWIF E MEDINA,2007).

Para inclusão no Arena, foram definidos os parâmetros de entrada abaixo que foram utilizados nas simulações dos cenários $(A)$ e $(B)$. Esses parâmetros foram classificados em duas etapas: do navio e do porto / transshipment.

Para o navio, foram definidos os itens de entrada detalhados na tabela 2:

Tabela 2 - Itens de entrada no Arena relacionados a navio.

\begin{tabular}{l|l}
\hline \multicolumn{2}{c}{ NAVIOS } \\
\hline \multicolumn{2}{c}{ Demanda total prevista } \\
\hline Demanda total prevista (t) & 10 milhões \\
\hline \multicolumn{2}{c}{ Capacidade embarcações } \\
\hline Capacidade Handymax T.U. & $45.000 \mathrm{t}$ \\
Capacidade Panamax & $70.000 \mathrm{t}$ \\
Capacidade Capesize & $160.000 \mathrm{t}$ \\
Prancha contratual & 20.000 \\
Número de carregadores T.U. & t/dia \\
\hline
\end{tabular}


A demanda total refere-se à produção atual da mina de Corumbá-MS. Nos itens seguintes da tabela são descritas as capacidades dos navios, a prancha total por dia (ritmo de carregamento) e a quantidade de carregadores T.U. disponíveis.

Já para o porto e transshipment, foi definido o uso de um berço e um carregador no porto e a produtividade de carregamento do terminal e da descarga do T.U. definida em 4.000 tph.

Para o navio carregador, ficou definido 1 T.U. disponível, realizando intervalo de limpeza a cada oito semanas, por seis horas. Nos itens relacionados ao tempo de ciclo no T.U., foi considerado o tempo de ciclo fechado e foram definidos os demais valores apresentados na tabela 3 :

Tabela 3 - Itens de entrada no Arena relacionados a porto e transshipment.

\begin{tabular}{l|c}
\hline \multicolumn{2}{c}{ PORTO E TRANSSHIPMENT } \\
\hline \multicolumn{1}{c}{ Porto - Terminal } \\
\hline Número de berços & 1 \\
Carregadores de navio & 1 \\
Produtividade de carga no terminal & $4.000 \mathrm{tph}$ \\
Produtividade do transshipment (T.U.) & $4.000 \mathrm{tph}$ \\
\hline \multicolumn{2}{c}{ T.U. } \\
\hline \multicolumn{2}{c}{ T.U em operação } \\
Intervalo entre limpezas & 8 \\
Tempo de limpeza & 6 horas \\
\hline \multicolumn{2}{c}{ Tempos adicionais } \\
\hline Tempo viagem porto-barra \\
Tempo viagem barra-porto \\
Tempo atracação T.U. na barra \\
Tempo desatracação T.U. na barra & $1,9 \mathrm{~h}$ \\
Tempo atracação T.U. no porto & $1,1 \mathrm{~h}$ \\
Tempo desatracação T.U. no porto & $0,9 \mathrm{~h}$ \\
\hline
\end{tabular}

\subsection{RESULTADOS DA ANÁLISE OPERACIONAL}

Realizadas as simulações dos cenários (A) e (B) de acordo com a implementação descrita no item anterior, chegou-se aos resultados que serão apresentados a seguir. 
Para o Cenário (A) - Operação convencional direta via terminal portuário, utilizando navios da classe Panamax, os resultados foram:

- Sistema atende a demanda (10 MPTA);

- Total navios Panamax carregados: 143;

- Taxa de ocupação do berço do terminal para operar o navio Panamax: $37 \%$;

Observa-se que o sistema consegue atender a demanda com navios Panamax, com uma utilização razoavelmente baixa do berço do terminal, o que indica pouco tempo de espera dos navios para atracar e operar.

Para o Cenário B - Operação com transshipment usando 1 navio da classe Handymax como alimentador e 1 navio da classe Capesize como principal fundeado na barra em Santos, chegou-se aos seguintes resultados:

- Sistema atende parcialmente a demanda (9 MPTA);

- Total de navios Capesize usados: 62;

- Taxa de ocupação do berço do terminal para operar o navio T.U.: $40 \%$;

- Tempo médio dos navios OGV na barra: 174 dias

- Taxa de ocupação na barra para transshipment: $86 \%$

- Tempo médio de ciclo do T.U. (dias): 1,59

Observa-se que o sistema de transshipment consegue atender de forma parcial a demanda e que a ocupação da barra é alta, o que indica que o navio exportador estaria aguardando um tempo alto para ser carregado.

Conclui-se que ambas as operações são viávies operacionalmente, porém com resultados bastante distintos. A tabela 4 apresenta um comparativo das simulações dos cenários (A) e (B). Através dela é possível concluir que ambos os cenários conseguem atender operacionalmente as demandas, porém com as seguintes ressalvas:

No cenário $(A)$ do Panamax, apesar de atender a demanda, gerou-se uma quantidade de navios OGV - ocean going vessel - navios exportadores bastante 
superior ao do cenário (B). Por outro lado, no cenário (B), o tempo médio dos navios na barra chega a 174 dias, devido a geração de fila de espera, já que o tempo é agravado ao fato de o Capesize ter que aguardar por um alto tempo o navio T.U. completar seus ciclos até finalizar o carregamento do volume total. Com isso, a demanda não é atendida em sua totalidade.

Tabela 4 - Resultados da simulação dos cenários (A) e (B)

\begin{tabular}{l|cc}
\cline { 2 - 3 } & $\begin{array}{c}\text { Cenário (A) } \\
\text { Panamax } \\
\text { direto }\end{array}$ & $\begin{array}{c}\text { Cenário (B) } \\
\text { Capesize + 1 TU } \\
\text { Demanda }\end{array}$ \\
\hline Atendida & $\begin{array}{c}\text { Atendida } \\
\text { parcialmente }\end{array}$ \\
\hline Total de navios OGV gerados & 143 & 62 \\
\hline Taxa ocupação berço & $37 \%$ & $40 \%$ \\
\hline Tempo médio dos navios OGV na barra (dias) & 0 & 174 \\
\hline Taxa ocupação barra & - & $86 \%$ \\
\hline Tempo médio ciclo T.U. (dias) & - & 1,59 \\
\hline
\end{tabular}

A figura 25 e a tabela 5 apresentam a composição dos tempos de ciclo do T.U. Observa-se que cerca de $60 \%$ do tempo de ciclo do T.U. é decorrente das operações de carregamento no terminal e transshipment na barra.

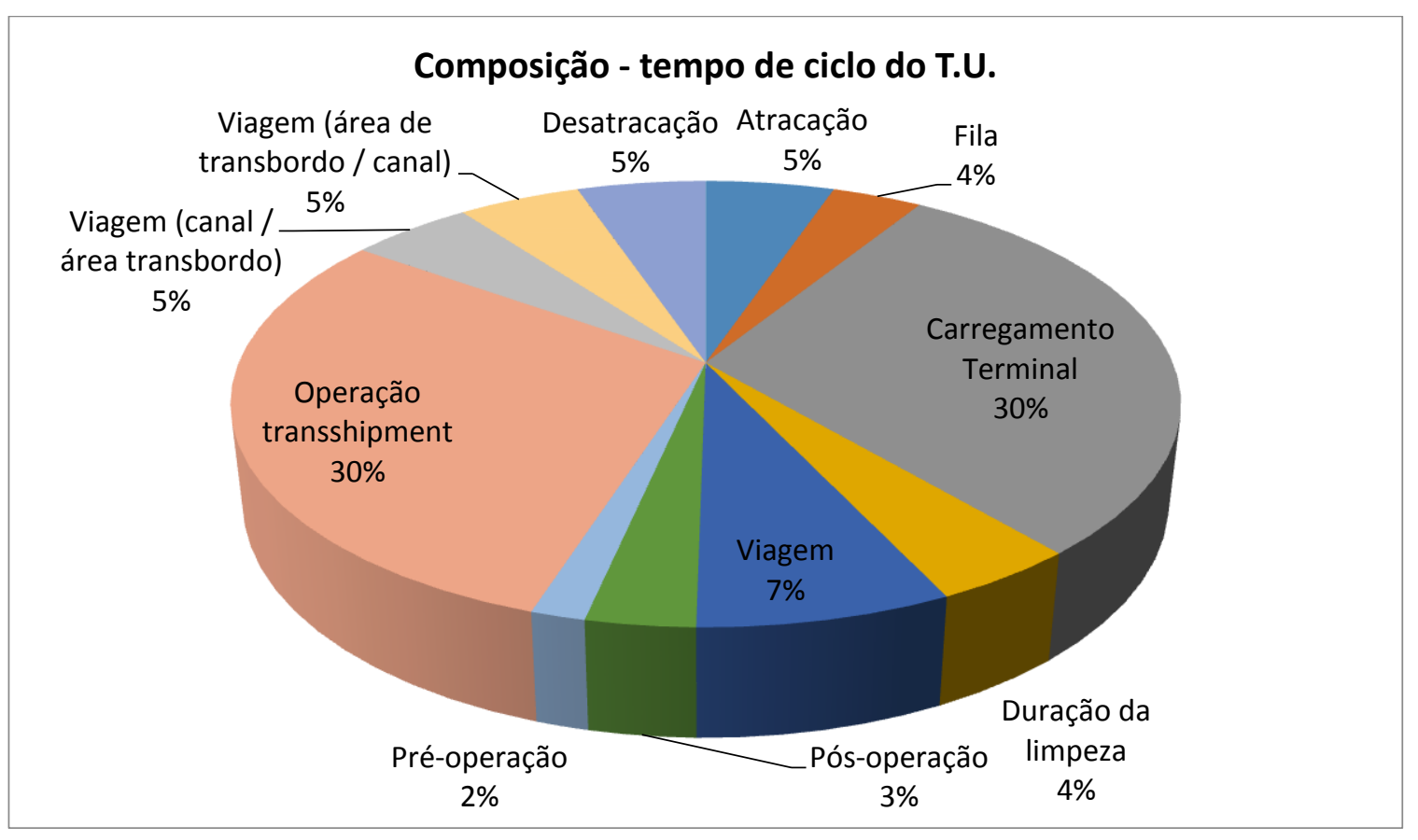

Figura 25 Composição do tempo de ciclo do T.U. 
Tabela 5 - Composição do tempo de ciclo do T.U.

\begin{tabular}{|c|c|c|c|}
\hline & Processo & $\begin{array}{l}\text { \% Tempo } \\
\text { de ciclo }\end{array}$ & $\begin{array}{c}\text { Tempo } \\
\text { (h) }\end{array}$ \\
\hline \multirow{5}{*}{ 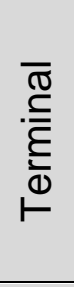 } & Atracação & $5 \%$ & 2,0 \\
\hline & Fila & $4 \%$ & 1,4 \\
\hline & Carregamento Terminal & $30 \%$ & 11,4 \\
\hline & Duração da limpeza & $4 \%$ & 1,6 \\
\hline & Viagem & $7 \%$ & 2,8 \\
\hline \multirow{6}{*}{ 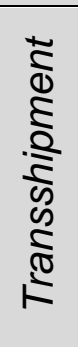 } & Pós-operação & $3 \%$ & 1,2 \\
\hline & Pré-operação & $2 \%$ & 0,6 \\
\hline & Operação transshipment & $30 \%$ & 11,4 \\
\hline & Viagem (canal / área transbordo) & $5 \%$ & 1,9 \\
\hline & Viagem (área de transbordo / canal) & $5 \%$ & 1,9 \\
\hline & Desatracação & $5 \%$ & 2,0 \\
\hline & Tempo de ciclo & 1,59 dias & $38,2 \mathrm{~h}$ \\
\hline
\end{tabular}

Realizando-se um benchmarking, ou seja, comparando-se os tempos da tabela $5 \mathrm{com}$ as de outras operações existentes no Brasil consideradas como de alta performance, chegam-se aos seguintes resultados:

Em relação ao tempo de atracação e desatracação do transshipment, observa-se que a operação ocorre com $2 \mathrm{~h}$ de duração cada, enquanto que no terminal de Tubarão-ES, por exemplo, ocorreu em média em 1,2h e na Ponta da Madeira-PA, em 2,8h cada, no ano de 2016 (ANTAQ, 2017).

Já o tempo de carregamento do navio Handymax T.U. no terminal ocorre em 11,4h, enquanto que em Tubarão ocorreu em 30,7h para navios em média 4,1 vezes maiores, em 2016 (ANTAQ, 2017).

\subsection{PROPOSTAS DE CENÁRIOS ADICIONAIS}

Diante dos resultados encontrados nas simulações, é possível concluir que, apesar de viável, a operação de transshipment desenhada no cenário (B) possui uma ineficiência relacionada ao tempo de espera de navio OGV na barra, quando comparada ao cenário convencional $(\mathrm{A})$, não atendendo a demanda em sua 
totalidade. Para checar se o tempo pode ser reduzido de alguma forma, é necessário testar novos cenários, mudando alguns parâmetros.

Nesta etapa, com o intuito de utilizar novos parâmetros nas simulações que trouxessem cenários o mais próximos possíveis do real, foi realizada uma entrevista com um profissional do ramo de corretagem de navios que possui conhecimento e experiência na tentativa de realizar operações de transshipment no Brasil. Por decisão metodológica, o entrevistado não será identificado, porém a transcrição de sua entrevista consta mencionada no apêndice deste trabalho.

O entrevistado atualmente é ship broker, que é um corretor de navios que participa como intermediário nos contatos entre o fretador e o afretador das embarcações. Usualmente estes contatos não são feitos diretamente entre as partes, sendo função do corretor realizar toda a interface para que elas consigam e possam realizar o aluguel do navio, de modo que a carga possa ser transportada (MENDONÇA E KEEDI, 1997).

Este intermediário tem a atribuição de entrar no mercado a procura das oportunidades solicitadas pelos seus clientes, ou seja, armadores, proprietários de navios, transportadores, embarcadores, etc, para tentar satisfazer suas necessidades. O ship broker realiza esta intermediação mediante uma comissão que Ihe é paga pelo fretador, em geral na base percentual (MENDONÇA E KEEDI, 1997).

O broker, durante a entrevista, relatou que trabalhou em um projeto de uma empresa que importava carvão que, diante do benefício do custo de frete utilizando um navio maior, solicitou uma operação de transshipment a ser realizada através do porto de São Sebastião.

Ele relatou que operacionalmente o teste dessa operação foi realizado no porto de São Sebastião-SP e foi bem sucedido, porém foi interrompido posteriormente devido a dificuldades de adequação da tripulação do navio, que por exigência da legislação, deveriam ser, segundo ele, de nacionalidade brasileira, sendo que a decisão pelo encerramento também teria sido acentuada pela queda de demanda no período.

Quando questionado sobre a viabilidade de se realizar uma operação similar para minério de ferro no porto de Santos-SP, ele apresentou as seguintes percepções: 
- Neste tipo de operação usualmente se utilizam dois navios T.U.s, para poder aumentar a produtividade de carregamento e descarga e diminuir o tempo de espera do navio OGV para embarque.

- Ao redor do mundo, esse tipo de operação é realizada principalmente em áreas de mar abrigado.

- A região da barra de Santos-SP, segundo ele, por ser de mar aberto, apresenta forte ondulação no mar, também conhecido como swell, dificultando significativamente esse tipo de operação.

- Quando indagado sobre o quanto a operação poderia ser impactada por condições climáticas adversas, ele sinalizou em $25 \%$ do tempo da operação.

- Sugeriu realizar simulação da operação através do porto de São SebastiãoSP, por ser o mais próximo do terminal a possuir condição de mar abrigado e oferta de chegadas de navios Capesize com carvão importado.

Com base nessas observações, foram estipulados e simulados novos cenários, que serão apresentados a seguir.

\subsubsection{Cenário adicionando um carregador T.U.}

Neste cenário de simulação $(C)$, foram mantidos os parâmetros do cenário (B) e incluída a utilização de 2 navios T.U. Handymax para carregar o navio Capesize na barra. Nele foi possível obter os seguintes resultados:

- Sistema atende a demanda (10 MPTA);

- Total de navios Capesize usados: 62;

- Taxa de ocupação do berço do terminal para operar os navios T.U. é de $44 \%$;

- Tempo médio dos navios OGV na barra: 2,5 dias

- Taxa de ocupação na barra para transshipment: $51 \%$

- Tempo médio de ciclo dos T.U.s (dias): 1,67

A tabela 6 mostra uma comparação entre os cenários B e C. Observa-se que a adição de um T.U. proporcionou a redução do tempo médio dos navios na barra 
para 2,5 dias, tornando o desempenho do sistema do cenário $\mathrm{C}$ mais adequado a proposta de transshipment, quando comparado ao sistema inicial.

Tabela 6 - Comparação de resultados das simulações dos cenários (B) e (C).

\begin{tabular}{l|cc}
\cline { 2 - 3 } & $\begin{array}{c}\text { Cenário (B) Capesize } \\
\mathbf{+ 1} \text { TU }\end{array}$ & $\begin{array}{c}\text { Cenário (C) } \\
\text { Capesize + 2 } \\
\text { TU }\end{array}$ \\
\hline Demanda & Atendida parcialmente & Atendida \\
\hline Total de navios OGV gerados & 62 & 62 \\
\hline Taxa ocupação berço & $40 \%$ & $44 \%$ \\
\hline Tempo médio dos navios OGV na barra (dias) & 174 & 2,5 \\
\hline Taxa ocupação barra & $86 \%$ & $51 \%$ \\
\hline Tempo médio ciclo T.U. (dias) & 1,59 & 1,67 \\
\hline
\end{tabular}

\subsubsection{Cenário considerando condições climáticas adversas}

Neste cenário (D), foi considerada na simulação adicionalmente nos parâmetros as seguintes variáveis: a operação de transshipment é afetada por condições climáticas adversas, como ventos e swell, em $25 \%$ do tempo, obtendo os seguintes resultados:

- Sistema atende a demanda (10 MPTA);

- Total de navios Capesize usados: 62;

- Taxa de ocupação do berço do terminal para operar os navios T.U. é de $41 \%$;

- Tempo médio dos navios OGV na barra: 3,4 dias;

- Taxa de ocupação na barra para transshipment: $55 \%$;

- Tempo médio de ciclo do T.U. (dias): 1,85;

A tabela 7 apresenta um comparativo entre os cenários (B), (C) e (D). Conclui-se que no cenário (D), devido ao impacto das condições climáticas no sistema, o tempo de espera dos navios OGV na barra aumenta em 0,9 dia, quando comparado ao cenário $(C)$, e o tempo do ciclo do T.U. sobe para 1,85 dias. 
Tabela 7 Comparação dos cenários B, C e D.

\begin{tabular}{l|ccc}
\cline { 2 - 4 } & $\begin{array}{c}\text { Cenário (B) Capesize } \\
+\mathbf{1} \text { TU }\end{array}$ & $\begin{array}{c}\text { Cenário (C) } \\
\text { Capesize + 2 } \\
\text { TU }\end{array}$ & $\begin{array}{c}\text { Cenário (D) } \\
\text { Capesize + 2 TU + } \\
\text { Condições } \\
\text { climáticas }\end{array}$ \\
\hline Demanda & Atendida parcialmente & Atendida & Atendida \\
\hline Total de navios OGV gerados & 62 & 62 & 62 \\
\hline Taxa ocupação berço & $40 \%$ & $44 \%$ & $41 \%$ \\
\hline Tempo médio dos navios OGV na barra (dias) & 174 & 2,5 & 3,4 \\
\hline Taxa ocupação barra & $86 \%$ & $51 \%$ & $55 \%$ \\
\hline Tempo médio ciclo T.U. (dias) & 1,59 & 1,67 & 1,85 \\
\hline
\end{tabular}

\subsubsection{Cenário considerando operação no porto de São Sebastião-SP}

Neste cenário $(\mathrm{E})$, foi considerado como base o cenário $(\mathrm{C})$, já que o porto de São Sebastião possui águas abrigadas para a realização do transshipment, não sofrendo impacto de condições climáticas, porém aumentando o parâmetro do tempo viagem porto-barra e barra-porto para 13,2h cada trecho, devido à maior distância do trecho terminal em Santos-SP para São Sebastião-SP. Com essas premissas, foi possível obter os seguintes resultados:

- Sistema atende a demanda (10 MPTA);

- Total de navios Capesize usados: 63;

- Taxa de ocupação do berço do terminal para operar os navios T.U. é de $39 \%$;

- Tempo médio dos navios OGV na barra: 15,5 dias

- Taxa de ocupação na barra para transshipment: $68 \%$

- Tempo médio de ciclo do T.U. (dias): 2,58

Observa-se que a taxa de ocupação do berço do terminal e da barra ficou razoavelmente abaixo da capacidade total, o que indica que o sistema possui capacidade de atender a um aumento de demanda de produção da mina de Corumbá-MS, se assim ocorrer. 
A tabela 8 apresenta um comparativo entre todos os cenários de transshipment simulados.

Tabela 8 Comparativo entre todos os cenários de transshipment simulados.

\begin{tabular}{l|cccc}
\cline { 2 - 5 } & $\begin{array}{c}\text { Cenário (B) Capesize } \\
+\mathbf{1} \text { TU }\end{array}$ & $\begin{array}{c}\text { Cenário (C) } \\
\text { Capesize + 2 } \\
\text { TU }\end{array}$ & $\begin{array}{c}\text { Cenário (D) } \\
\text { Capesize + 2 TU } \\
+ \text { Condições } \\
\text { climáticas }\end{array}$ & $\begin{array}{c}\text { Cenário (E) } \\
\text { Capesize + 2 } \\
\text { TU em São } \\
\text { Sebastião }\end{array}$ \\
\hline Demanda & Atendida parcialmente & Atendida & Atendida & Atendida \\
\hline Total de navios OGV & 62 & 62 & 62 & 63 \\
\hline Taxa ocupação berço & $40 \%$ & $44 \%$ & $41 \%$ & $39 \%$ \\
\hline $\begin{array}{l}\text { Tempo médio dos navios } \\
\text { OGV na barra (dias) }\end{array}$ & 174 & 2,5 & 3,4 & 15,5 \\
\hline Taxa ocupação barra & $86 \%$ & $51 \%$ & $55 \%$ & $68 \%$ \\
\hline $\begin{array}{l}\text { Tempo médio ciclo T.U. } \\
\text { (dias) }\end{array}$ & 1,59 & 1,67 & 1,85 & 2,58
\end{tabular}

\subsection{ANÁLISES DE SENSIBILIDADE}

A seguir, foram realizadas algumas análises de sensibilidade afim de quantificar o quanto a mudança de determinados parâmetros impactam o sistema como um todo.

Diante dos cenários que foram analisados no item anterior, foram escolhidos três principais parâmetros para a realização das análises, sendo eles: a taxa de produtividade de carregamento e descarga, as condições ambientais e a localização do ponto de transsipment.

\subsubsection{Efeito da taxa de carregamento na operação de transshipment}

Para identificar a influência da taxa de produtividade no sistema, foram realizadas análises de sensibilidade, variando-se as capacidades entre 1.000 a 6.000 tph no cenário (D) - navio Capesize sendo atendido por 2 T.U.s, sob efeito de condições climáticas adversas.

A figura 26 apresenta esse resultado. Observa-se que utilizar uma taxa de carregamento entre 1.000 e 2.000 tph inviabiliza a operação sob o ponto de vista de tempo de espera do navio para carregamento. A partir de 3.000 tph, o tempo de espera reduz significativamente, ficando em patamar abaixo de 10 dias. 


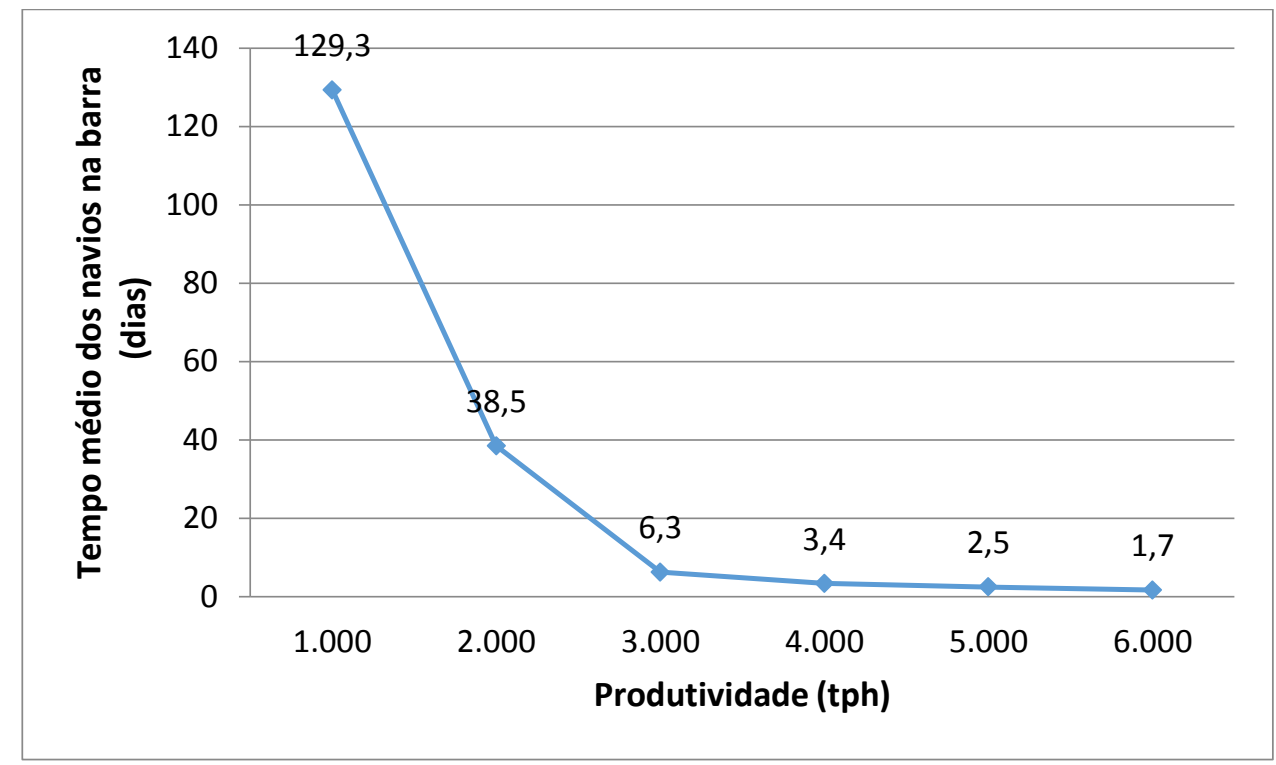

Figura 26 Efeito na taxa de carregamento no tempo de espera dos navios

\subsubsection{Efeito das condições climáticas no tempo de espera dos navios}

Neste item, com o intuito de identificar o quanto as condições ambientais podem impactar no tempo de espera dos navios na barra, foram realizadas análises de sensibilidade, considerando que em 0\%, 25\%, 50\% e 75\% o tempo de operação seria afetado por condições climáticas adversas para a operação de transshipment em Santos. A figura 27 apresenta esse resultado. Observa-se que a partir do cenário de $50 \%$ de impacto, o aumento na espera dos navios cresce substancialmente.

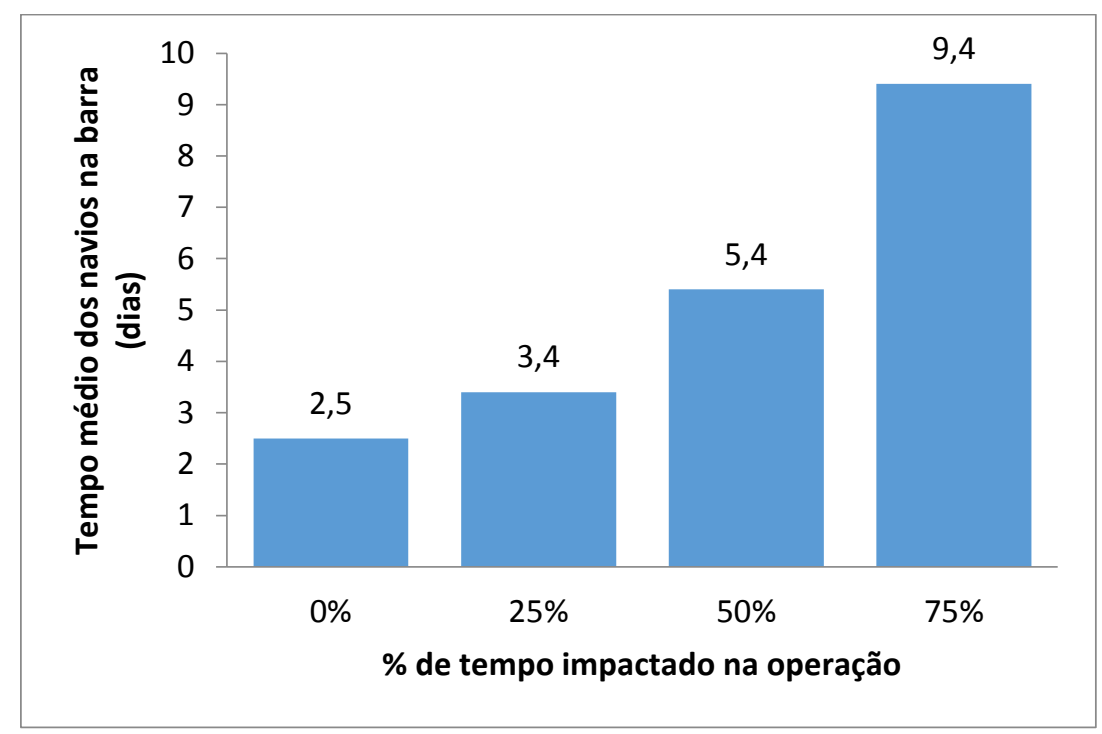

Figura 27 - Efeito de condições climáticas adversas no tempo médio de espera dos navios na barra. 


\subsubsection{Efeito da distância do local do transshipment no tempo de espera dos navios}

Nesta análise de sensibilidade foi verificado o quanto a distância do local do transshipment em relação ao porto impacta no tempo médio de espera dos navios na barra. A figura 28 apresenta o resultado. Para Santos, o tempo média de espera dos navios é de 3,4 dias. Para São Sebastião, o tempo de espera sobe para 15,5 dias.

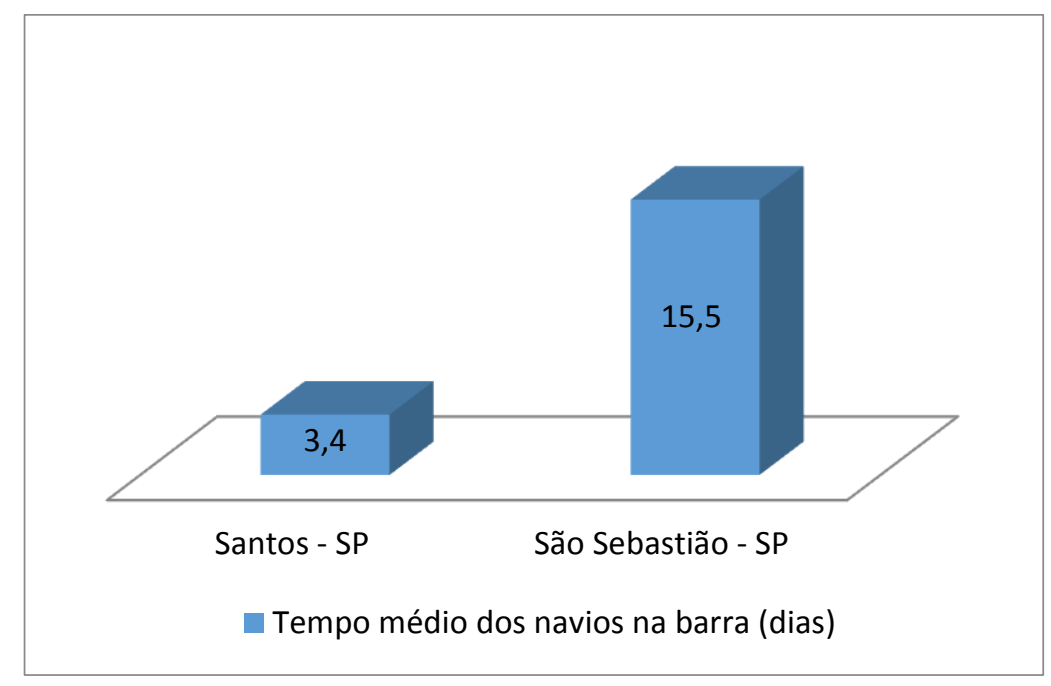

Figura 28 - Efeito da distância do local do transshipment no tempo de espera dos navios na barra.

\subsection{CONCLUSÕES DA ANÁLISE OPERACIONAL}

Através das simulações e análises de sensibilidade realizadas neste capítulo, foi possível concluir que o cenário inicial de transshipment com 1 T.U., apesar de atender a demanda, deixa o navio OGV por um longo período de espera na barra em Santos.

A partir disso, o cenário de utilização de 2 carregadores T.U.s se tornou mais adequado, por atender de forma mais rápida a carga e descarga e reduzir o tempo de espera dos navios OGV em $98,6 \%$, chegando a dois dias e meio de espera.

Porém, há que se considerar que pelo fato da barra do porto de Santos-SP ser um local de mar aberto, o sistema poderá sofrer interrupções ocasionadas por 
condições climáticas adversas, como por exemplo, forte swell. Desta forma, realizando as simulações com impactos em $25 \%, 50 \%$ e $75 \%$ do tempo de operação, observa-se que ainda assim o sistema consegue atender a demanda, porém, nos dois ultimos cenários, o tempo de espera dos navios aumenta consideravelmente.

Quando analisada a possibilidade de se realizar a operação de transshipment em mar abrigado, como no caso da carga saindo do terminal em Santos-SP para a realização do transbordo no mar do porto de São Sebastião-SP, é possível concluir pelas simulações que o sistema consegue atender a demanda, porém, o tempo do ciclo do navio T.U. aumenta em mais de $400 \%$.

Tendo em vista que os principais parâmetros que podem ser impactados no sistema são o tempo de espera do navio principal - OGV e o tempo de ciclo do T.U., no capítulo seguinte será realizada uma análise de custo logístico total da operação para identificar quais dos cenários analisados torna-se possível tanto do ponto de vista operacional, quanto do ponto de vista de custos. 


\section{$8 \quad$ ANÁLISE DE CUSTO LOGÍSTICO TOTAL}

Para analisar a operação de transshipment sob o ponto de vista de custos, foi utilizado o conceito de custo logístico total anual para a análise, visto que a proposta é avaliar os valores de uma operação desse tipo sob o ponto de vista do embarcador da mercadoria, para um ano de operação.

Neste capítulo foram explicados os conceitos de custo logístico total e detalhados todos os custos marítimos considerados nas análises. Em seguida, foram apresentadas as análises dos cenários e as conclusões obtidas através delas.

\subsection{CONCEITO DE CUSTO LOGÍSTICO TOTAL}

O conceito de custo logístico total foi introduzido pela primeira vez em 1956 quando foram incluídos neste todos os valores que eram necessários para responder aos requisitos de um sistema logístico. Até então, as empresas procuravam atingir o menor valor possível em cada componente do custo logístico, sem dar grande relevância ao total. A partir de então foi defendido que a forma de alcançar a situação ótima (maior satisfação do cliente ao menor custo) seria por meio do custo total: as empresas deveriam concentrar-se na redução do custo total logístico, mesmo que parte deles não tivessem o menor valor possível. Este conceito defendeu uma visão integrada da logística e desencadeou um aprofundamento do tema, assim como da análise da relação entre eles (BOWERSOX, CLOSS E COOPER, 2011).

Segundo Ballou (2006), o item principal para o escopo e o projeto do sistema logístico é a análise de compensação (trade-off) que leva ao conceito de custo total. Os conceitos de custo total e compensação de custos caminham juntos. Ele conclui que os custos individuais exibem comportamentos conflitantes, devendo ser balanceados no ótimo. O custo total para determinado número de armazéns é a soma dos três custos, formando a curva do custo total e chegando ao ponto ótimo.

De forma geral, este conceito defende o agrupamento de custos em centros de atividade, também chamadas de activity basis, contestando a prática comum de 
se utilizar uma base normal de custos, por esta última dificultar a identificação das atividades que correspondem ao maior valor. O custo total procura relacionar as despesas relevantes com as atividades de valor desempenhadas. O menor custo total origina-se por compensações entre os vários centros de atividade (BOWERSOX E CLOSS, 1996).

Observa-se que, além da identificação dos custos de cada centro de atividade, também devem ser identificados os fatores que os influenciam, de forma a facilitar a tomada de decisão. A análise de custo total é muitas vezes focada nos custos de armazenagem e de transporte e estes podem ser definidos num formato tal que abranja os custos de atividade dos componentes logísticos com eles relacionados (BOWERSOX, CLOSS E COOPER, 2011).

Os métodos principais de análise de sistemas logísticos que se baseiam no conceito de custo total são: análise estática e análise dinâmica. Estes métodos comparam dois ou mais sistemas logísticos alternativos, calculando qual deles tem o menor valor total em determinada situação concreta (BOWERSOX, CLOSS E COOPER, 2011).

Em uma análise estática, é abordada uma situação sem alteração e os custos são divididos em centros de atividade. A informação referente aos custos é desenvolvida para cada um dos sistemas em análise. Em seguida, é selecionado o sistema que corresponde ao menor custo total (BOWERSOX, CLOSS E COOPER, 2011).

Já na análise dinâmica, o sistema ótimo é determinado com base no cálculo matemático do ponto de igualdade entre os sistemas em questão. Os sistemas podem ser representados por uma equação linear do tipo $y=a+b x$, em que (a) representa os custos fixos, (b) os custos variáveis por unidade e (x) o nível de saída. A partir da representação gráfica dos sistemas, pode se decidir qual o sistema indicado, em função do nível de resultado que se pretenda. O ponto de igualdade corresponde à situação em que é indiferente escolher entre os sistemas, já que ambos possuem o mesmo custo total (BOWERSOX, CLOSS E COOPER, 2011).

Para o problema do transshipment foi realizada uma análise estática. Foram levantados os valores que compõem uma operação de transshipment de minério de ferro em Santos-SP durante o período de um ano, nos cenários vistos anteriormente, 
e feita uma comparação com a operação convencional para o mesmo período, identificando qual possui menor custo logístico total anual.

A análise foi realizada sob o ponto de vista do embarcador da mercadoria, ou seja, envolveu os custos logísticos que estes teriam ao realizar uma operação desse tipo no Brasil até a entrega da mercadoria no porto de destino. Isso porque, no comércio internacional, a comercialização de carga seca a granel usualmente acontece na modalidade de incoterm ${ }^{6}$ CIF, ou seja, onde o embarcador arca com todos os custos de transporte e seguro, até o porto de destino. (KEEDI, 2011). Porém, nesse caso, tendo em vista que a proposta nessa análise é dar enfoque aos custos logísticos, não foram considerados os custos da mercadoria (bem como o seguro) na análise.

O período considerado para análise foi de 1 (um) ano de operação, ou seja, o tempo em que uma demanda de 10.000.000 t da mina de Corumbá-MS deve ser escoada no sistema.

Os centros de atividade levantados para custeio, como explicado anteriormente, devem englobar itens de armazenagem e de transporte do sistema. Desta forma, no item de armazenagem, foram levantados os custos portuários que envolvem a operação do terminal portuário armazenador e expedidor e do porto como um todo. Já no transporte, foram levantados os custos que compõem o frete marítimo e do navio carregador T.U.

Esse trabalho, ainda, não deu enfoque ao custo da construção de um terminal de uso privativo - TUP - de minério em Santos, já que entende-se que para se realizar a operação, o terminal deverá existir de qualquer forma.

\subsection{CUSTOS LOGÍSTICOS PARA OPERAÇÕES MARÍTIMAS}

Os custos que compõem o frete marítimo são: o aluguel do navio para a rota, também denominado time charter (TC), as despesas de combustível, também conhecidas como bunker, e as despesas portuárias (BERTOLOTO, 2010).

A figura 29 representa a composição dos custos de frete marítimo. No caso da carga a granel, para se chegar ao frete por tolenada, o custo total deve ser

\footnotetext{
${ }^{6}$ Incoterms é um termo em inglês que é a abreviatura de International Commercial Terms, que em português significa "Termos Internacionais de Comércio". Trata-se de normas padronizadas que regulam alguns aspectos do comércio internacional.
} 
dividido pela tonelagem total transportada no navio. Ainda, devido ao fato do transporte marítimo ser usualmente de fronteiras internacionais, seus custos são negociados em dólar e posteriormente convertidos à moeda do pagador (BERTOLOTO, 2010). Por esse motivo, todas as análises deste capítulo foram realizadas na moeda americana, dólares (US\$).

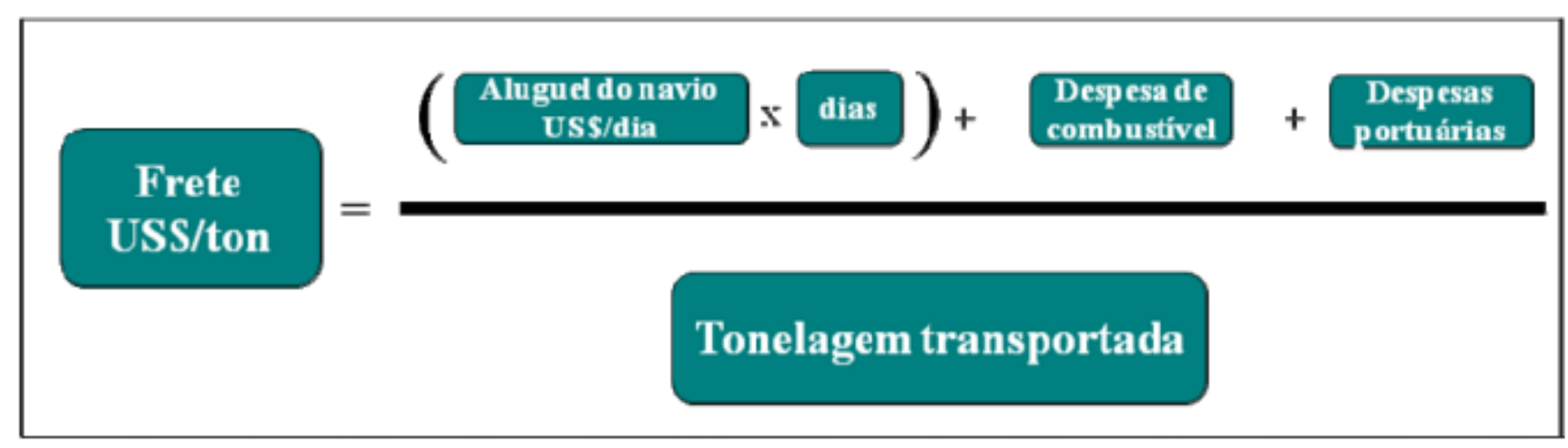

Figura 29 - Composição do frete marítimo. Fonte: BERTOLOTO, 2010.

A seguir foram detalhados todos os custos mencionados na figura 29. Primeiramente, para os navios exportadores, foram pesquisados seus fretes atuais por tonelada para a China. Para o navio carregador T.U., foi pesquisado seu custo de aluguel, bem como sua despesa de combustível para realizar uma operação de transshipment. Ao final, foram levantados os custos portuários em Santos para se realizar as operações

A figura 30 apresenta um resumo de todos os custos levantados para cada tipo de operação simulada. Ela está dividida em custos no porto de origem, no trânsito e no destino.

Como esclarecido anteriormente, não foram considerados os custos de destino na análise, pois a operação está considerada na modalidade CIF.

Os custos de origem são os provenientes da operação em Santos, que são: o aluguel do navio T.U., o combustível para o T.U., os custos portuários e os custos adicionais. No trânsito, foram considerados os custos de frete com destino à China. Todos esses custos serão explicados a seguir em tópicos individuais. 


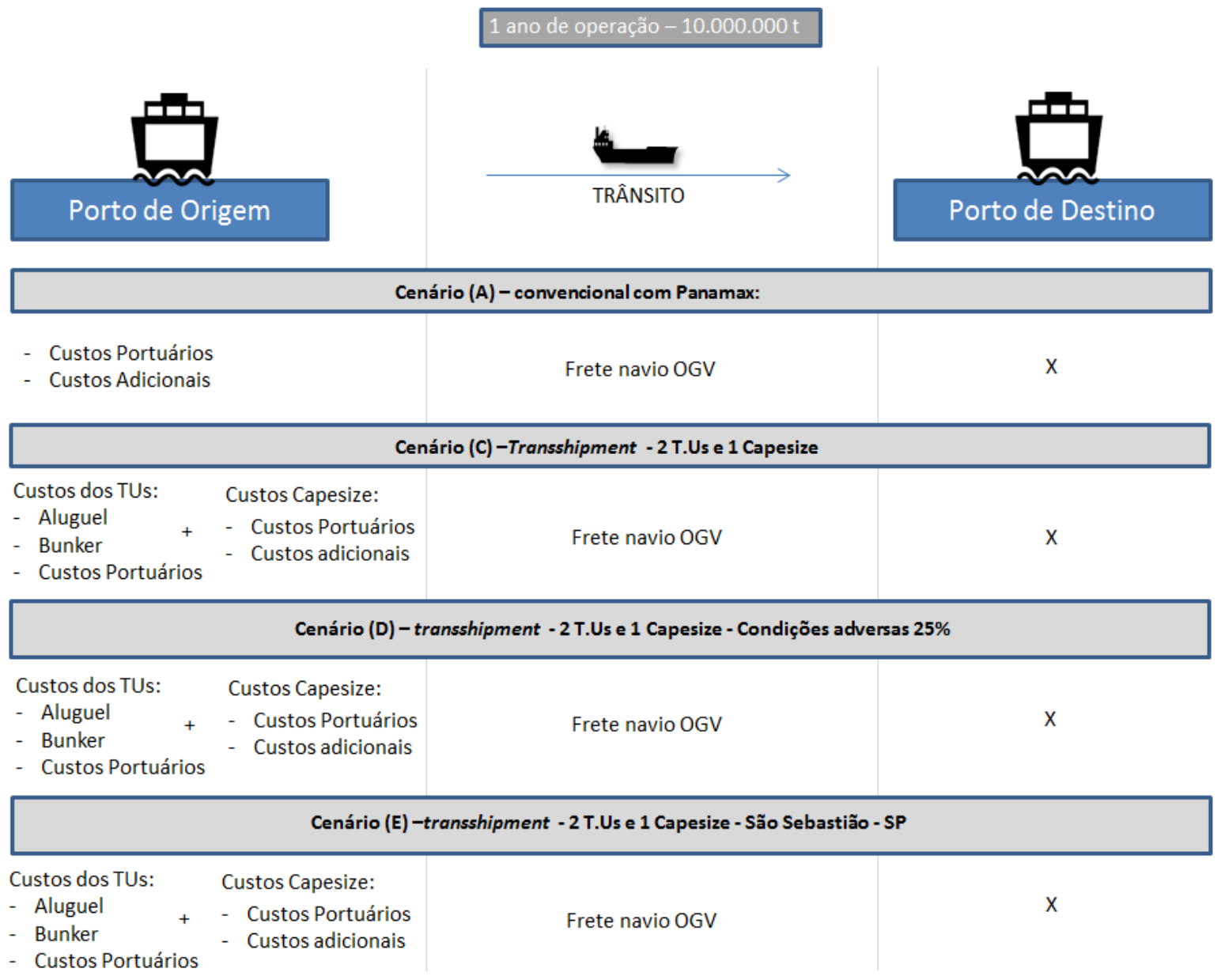

Figura 30 - Resumo dos custos logísticos levantados para cada cenário de operação.

\subsubsection{Frete}

Para os navios exportadores da classe Panamax e Capesize, o frete usualmente é pago em dólares por tonelada. Dessa forma, na análise, foram considerados os fretes de um navio Panamax e de um Capesize partindo de SantosSP para a cidade de Qingdao, na China. Os preços de frete marítimo variam conforme as condições de oferta e demanda do mercado, por isso, possuem alta variação em determinados períodos e, diariamente, tem seus valores alterados (BERTOLOTO, 2010).

Esses valores de frete foram obtidos através da provedora Platts, empresa que fornece informações de preços relacionados a commodities como o minério de ferro. A cidade escolhida foi Qingdao por ser umas das maiores cidades recebedoras de minério de ferro na China (PLATTS, 2017). 
Após obter os valores de frete, estes foram multiplicados pela capacidade total carregada nos navios, em tonelada.

\subsubsection{Aluguel do navio - time charter}

O aluguel do navio, também conhecido como taxa de afretamento ou time charter, é computado em forma de diária, logo seu custo em um dia é multiplicado pelo período de sua utilização, que equivale à soma dos dias de viagem, bem como dos dias de operação de carga e descarga. O aluguel do navio é um serviço e, como qualquer outro, seu preço responde às condições de oferta e demanda do mercado (BERTOLOTO, 2010).

Para esta análise, foi realizada uma cotação com broker para um aluguel de um navio T.U. da classe Handymax. O custo utilizado na análise foi o obtido no momento da cotação, em dólares americanos, para utilização de um navio deste tipo em uma operação em Santos-SP.

\subsubsection{Despesa de combustível - bunker}

Para a despesa de combustível (ou bunker) do navio carregador T.U., foi pesquisado o consumo médio de um navio desse tipo, ponderando entre a realização da operação de transshipment, a navegação entre o terminal e a região da barra em Santos-SP, onde o navio exportador é ancorado. O consumo médio foi obtido para um navio similar ao utilizado na simulação, através da Oldendorff (2016).

A tabela 9 apresenta um resumo do consumo de combustível de um navio carregador em diferentes situações. Os principais tipos de combustível usados no navio carregador são denominados IFO e MDO (OLDENDORFF, 2016).

O IFO - intermediate fuel oil, ou óleo combustível intermediário, é um combustível usado no motor principal do navio. O MDO - marine diesel oil, ou óleo diesel marítimo, é utilizado pelos geradores do navio (OLDENDORFF, 2016). 
Tabela 9 - Consumo de combustível do navio carregador. Fonte: Oldendorff, 2016.

\begin{tabular}{l|cccc}
\hline \multicolumn{4}{c}{ Consumo (toneladas por dia) } \\
\hline & Velocidade & Motor principal & Geradores \\
\cline { 2 - 5 } & Carregado Lastro & IFO & MDO \\
\cline { 2 - 5 } Navegação no mar & 14 & 14,5 & 35 & 0,5 \\
\hline Porto / Ancorado & & 3 & 0,5 \\
\hline Carregando / Descarregando & 10 & 0,5 \\
\hline
\end{tabular}

Em seguida, foi pesquisado o preço atual por tonelada para esses dois tipos de combustível no porto de Santos-SP através do Bunker Daily Report, relatório diário de preços de combustíveis marítimos elaborado pela Petrobrás Marine, empresa que detém o fornecimento de combustível em todos os portos do país. Tal tabela utilizada consta mencionada no anexo deste trabalho (PETROBRAS MARINE, 2017).

\subsubsection{Custos portuários}

Os custos portuários são aqueles relativos às cobranças de autoridades portuárias, terminais, agências e demais envolvidos para proceder com a operação no porto, movimentar o navio, inspecioná-lo e liberá-lo para seguir viagem (KEEDI, 2011).

Para os custos portuários da operação do navio Panamax convencional, foi usado como referência um PDA - proforma disbursement account, ou conta portuária de desembolso, que nada mais é do que um resumo das cobranças portuárias de uma operação marítima. Tal PDA apresenta os custos de uma operação de minério ferro realizada no Porto de Santos-SP para um navio da classe Panamax e está no anexo deste trabalho.

A tabela 10 apresenta os custos portuários considerados para um navio do tipo Panamax em uma operação convencional de exportação de minério de ferro pelo Porto de Santos-SP. A descrição de cada uma das despesas pode ser consultada no anexo deste trabalho. 
Tabela 10 - Resumo dos custos portuários para navio Panamax em dólares US\$. Fonte: PDA, 2017.

\begin{tabular}{llc}
\hline Despesa portuária & Tradução & Panamax direto \\
\hline Light dues & Taxa de Farol & $2.250,00$ \\
\hline Funapol - Federal Police & Fundo para Polícia Federal & 342,29 \\
\hline Clearance & Liberação aduaneira & $1.050,00$ \\
\hline Pilotage in/out & Praticagem entrada e saída & $18.564,08$ \\
\hline Pilotage for anchoring & Praticagem de fundeio & \\
\hline Towage & Rebocadores & $40.733,00$ \\
\hline Watchmen & Vigia de bordo & - \\
\hline Channel dues & Taxas de Canal & - \\
\hline Wharfage & Capatazia & - \\
\hline Launch hire & Lancha & - \\
\hline Car hire & Carro & 250,00 \\
\hline Communication / postage & Comunicação / postagens & 250,00 \\
\hline Agency fee & Taxa da Agência & $3.000,00$ \\
\hline Municipal tax & Taxa Municipal & 136,50 \\
\hline IOF & IOF & - \\
\hline Port State Control Survey & Controle Portuário & - \\
\hline Certificates expenses & Despesas com certificados & 342,17 \\
\hline Ship owners tax - Sindamar & Taxa do Sindicato & 130,00 \\
\hline
\end{tabular}

Para os custos portuários da operação de transshipment, foi realizada uma cotação com broker para obtenção dos valores portuários estimados para se realizar uma operação do tipo. A tabela 11 apresenta as despesas portuárias consideradas para o navio carregador T.U. operar, bem como para eventuais abastecimentos deste navio no terminal, e ainda os custos portuários do navio Capesize exportador fundeado na barra.

Tabela 11 - Resumo de custos portuários para navio carregador T.U. e Capesize exportador US\$. Fonte: Cotação, 2017.

\begin{tabular}{l|l|r|r|r} 
Despesa portuária & Tradução & Navio T.U. & $\begin{array}{c}\text { Abastecimento } \\
\text { T.U }\end{array}$ & $\begin{array}{l}\text { Capesize } \\
\text { OGV }\end{array}$ \\
\hline Light dues & Taxa de Farol & $2.250,00$ & & $2.250,00$ \\
\hline Funapol - Federal Police & Fundo para Pol. Federal & 313,00 & 313,00 & 350,00 \\
\hline Clearance & Liberação aduaneira & $1.200,00$ & & \\
\hline Pilotage in/out & Praticagem entrada e saída & $10.373,00$ & $10.373,00$ & $20.127,00$ \\
\hline Pilotage for anchoring & Praticagem de fundeio & $8.360,00$ & & \\
\hline Towage & Rebocadores & $24.625,00$ & & \\
\hline Watchmen & Vigia de bordo & 740,00 & 740,00 & \\
\hline
\end{tabular}




\begin{tabular}{l|l|r|r|r} 
Despesa portuária & Tradução & Navio T.U. & $\begin{array}{c}\text { Abastecimento } \\
\text { T.U }\end{array}$ & $\begin{array}{l}\text { Capesize } \\
\text { OGV }\end{array}$ \\
\hline Channel dues & Taxas de Canal & - & $1.235,00$ & \\
\hline Wharfage & Capatazia & - & - \\
\hline Launch hire & Lancha & 750,00 & 975,00 & \\
\hline Car hire & Carro & 200,00 & & \\
\hline Communication / postage & Comunicação / postagens & 250,00 & & \\
\hline Agency fee & Taxa da Agência & $2.500,00$ & $1.500,00$ & $3.500,00$ \\
\hline Municipal tax & Taxa Municipal & 120,00 & & \\
\hline IOF & IOF & 10,53 & & \\
\hline Port State Control Survey & Controle Portuário & 529,42 & & \\
\hline Certificates expenses & Despesas com certificados & $1.588,24$ & & \\
\hline Ship owners tax -Sindamar & Taxa do Sindicato & 110,00 & 110,00 & \\
\hline
\end{tabular}

\subsubsection{Custos adicionais}

Tendo em vista que nas simulações realizadas observou-se que em alguns cenários o tempo de espera dos navios era alto enquanto a operação era realizada, também foi contemplado na análise o custo de demurrage, ou sobrestadia, dos navios, nas análises de custo total.

Segundo Mendonça e Keedi (1997), demurrage é uma multa que o contratante paga ao fretador se o navio permanece com ele por mais tempo que o acordado. Quando ocorre um afretamento de navio, esta é sempre uma das cláusulas estabelecidas na negociação.

O exportador garante um tempo mínimo para realizar a operação, conhecido como laytime, ou como prancha contratual. O laytime (tempo de permanência) é a quantidade de tempo permitida (normalmente em dias) numa viagem para o carregamento e descarregamento da carga. Também pode ser apresentado em taxa de carregamento ou descarga acordada por dia, que se traduz em dias ou fração de dias para se realizar a operação. Se o tempo for ultrapassado, a demora é cobrada por uma taxa, que normalmente é cobrada em diárias ou fração (MENDONÇA E KEEDI, 1997).

Por outro lado, pode ocorrer também o despatch, que é o inverso do demurrage, ou seja, é um prêmio pago pelo armador, ao embarcador, pela eficiência 
na operação do navio. Em geral equivale a $50 \%$ do custo de demurrage, e é mais aplicada em navios de operações de carga seca a granel (MENDONÇA E KEEDI, 1997).

Há, ainda, a utilização do turn time, ou free time, que é uma espécie de atraso no início da contagem do laytime, ou tempo de carência, que compreende o tempo estabelecido para se preparar o navio para carregar ou descarregar, como por exemplo, preparar equipamentos, abrir escotilhas, entre outros (MENDONÇA E KEEDI, 1997).

Desta forma, foram considerados nas análises, além dos custos já informados, o possível custo de demurrage no embarque nos casos em que os navios exportadores ultrapassarem o laytime estipulado, como também o despatch, em casos de antecipação. Não foram considerados custos de demurrage para os navios carregadores, visto que estas embarcações são pagas em forma de aluguel, ou time charter.

A tabela 12 apresenta as premissas consideradas para o cálculo de demurrage e despatch gerados nos cenários que serão apresentados no próximo item.

Tabela 12 - Premissas para o cálculo de demurrage / despatch

\begin{tabular}{lc}
\hline Premissa & Valor \\
\hline Turn time/ free time $(\mathrm{h})$ & 12 \\
\hline Lay time / prancha contratual (tpd) & 20.000 \\
\hline Demurrage Panamax (US\$/dia) & $15.000,00$ \\
\hline Demurrage Capesize (US\$/dia) & $25.000,00$ \\
\hline Despatch Panamax (US $\$$ /dia) & $7.500,00$ \\
\hline Despatch Capesize (US $\$$ dia) & $12.500,00$ \\
\hline
\end{tabular}

\subsection{ANALISE DE CUSTO TOTAL ANUAL DOS CENÁRIOS}

A seguir serão apresentadas as análises de custo logístico total realizadas para os seguintes sistemas:

- Cenário A: Operação convencional direta via terminal portuário, utilizando navios da classe Panamax. 
- Cenário C: Operação de transshipment usando 2 navios da classe Handymax como alimentadores e 1 navio da classe Capesize como principal fundeado em mar aberto em Santos.

- Cenário D: Operação de transshipment usando 2 navios da classe Handymax como alimentadores e 1 navio da classe Capesize como principal fundeado em mar aberto em Santos, com impacto de condições adversas em $25 \%$ do tempo da operação.

- Cenário E: Operação de transshipment usando 2 navios da classe Handymax como alimentadores e 1 navio da classe Capesize como principal fundeado em mar abrigado em São Sebastião-SP.

Observa-se que o cenário (B) não foi considerado, pois conforme análise operacional realizada no capítulo anterior, com somente 1 T.U., a demanda era atendida de forma parcial.

O passo a passo dos cálculos foi apresentado através de fórmulas e resumidos em tabelas com os custos relacionados para cada cenário. Ao final, foram realizados comparativos dos valores totais dos cenários para verificar qual possui menor custo logístico total sendo, portanto, a melhor opção para o embarcador.

\subsubsection{Custo logístico para a operação convencional (A) - Panamax}

Nesta análise, foram considerados inicialmente os custos para uma operação convencional de exportação usando Panamax $\left(F t_{(p)}\right)$, sendo estes: o frete $\left(a_{(p)}\right)$ multiplicado pela capacidade do navio $\left(x_{(p)}\right)$, conforme fórmula abaixo:

$$
F t_{(p)}=a_{(p)} \cdot x_{(p)}
$$

Para se chegar ao custo total de uma operação de Panamax $\left(C t_{(p)}\right)$, foram somados os custos portuários $(b)$, conforme abaixo: 


$$
C t_{(p)}=F t_{(p)}+b
$$

Após, foi calculado o custo total anual $\left(\mathrm{Cta}_{(p)}\right)$, considerando, através dos números obtidos na simulação, a quantidade de navios necessária $\left(y_{(p)}\right)$ para o atendimento total da demanda anual de 10 milhões de toneladas, conforme segue:

$$
C t a_{(p)}=C t_{(p)} \cdot y_{(p)}
$$

Durante a simulação, não houve resultado de demurrage $(d)$ para esta operação, mas houve despatch $(e)$, chegando-se a um custo logístico total anual do cenário $(\mathrm{A})(\operatorname{Clt}(A))$ conforme fórmula abaixo, totalizando US\$221.848.662,80. $\mathrm{A}$ tabela 13 apresenta um resumo desta análise para o cenário $(A)$.

$$
\operatorname{Clt}(A)=\operatorname{Cta}_{(p)}+d-e
$$

\begin{tabular}{|c|c|c|}
\hline \multicolumn{3}{|c|}{ Custo logístico total - operação Panamax direto } \\
\hline Descrição & Valor & Unidade \\
\hline Capacidade Panamax $-x_{(p)}$ & 70.000 & $\mathrm{t}$ \\
\hline Frete Panamax - $a_{(p)}$ & 21,5 & US $\$ / t$ \\
\hline Frete total - 1 navio $-F t_{(p)}$ & $1.505 .000,00$ & US\$ \\
\hline Custos portuários - $b$ & $67.048,04$ & US\$ \\
\hline Total $-C t_{(p)}$ & 1.572.048,04 & US\$ \\
\hline Panamax necessários ano $-y_{(p)}$ & 143 & \\
\hline Custo total ano $-C t a_{(p)}$ & 224.802.869,72 & US\$ \\
\hline Custo anual de demurrage - $d$ & 0 & US\$ \\
\hline Economia anual despatch - $e$ & 2.954.206,92 & US\$ \\
\hline Custo logístico total ano - $C l t(A)$ & $221.848 .662,80$ & US\$ \\
\hline
\end{tabular}

Tabela 13 - Custo logístico total anual - Operação convencional Panamax

\subsubsection{Custo logístico para o Cenário (C): transshipment com 2 T.U. e 1 Capesize}

Nesta análise, foram levantados inicialmente os valores para se calcular o custo do navio carregador T.U. para carregar 1 Capesize, que são: 
- custo do aluguel ou time charter (tc)

- tempo de ciclo do T.U. para carregar o Capesize $(z)$

- custos de combustível para atender 1 Capesize (bu)

- custos portuários para atender 1 Capesize $(b)$

Tais custos foram multiplicados por 2 (dois) que é a quantidade de navios carregadores utilizados $(t u)$, chegando-se ao valor total que os T.U.s geram para se atender 1 (um) navio Capesize $\left(C t_{(t u)}\right)$

$$
C t_{(t u)}=t c \cdot t u \cdot z+(b u \cdot t u)+(b \cdot t u)
$$

Em seguida, foi multiplicada a quantidade de Capesizes necessários para se atender a demanda total anual $\left(y_{(c)}\right)$ pelo custo total de uma operação $\left(C t_{(t u)}\right)$. foi somado a isso o custo portuário estimado para os navios carregadores eventualmente abastecerem no porto ao longo do ano $(b c)$ (seu abastecimento usualmente é realizado no mar, enquanto realiza a operação), totalizando US\$ 33.602.103,22:

$$
C t a_{(t u)}=\left(C t_{(t u)} \cdot y_{(c)}\right)+b c
$$

Para o frete do Capesize $\left(F t_{(c)}\right)$, foram levantados os custos de frete em US\$/t $\left(a_{(c)}\right)$ e multiplicado pela capacidade do navio $\left(x_{(c)}\right)$ :

$$
F t_{(c)}=a_{(c)} \cdot x_{(c)}
$$

Foi somado aos custos portuários $\left(b_{(c)}\right)$, chegando-se ao custo total para 1 (um) navio Capesize $C t_{(c)}$ :

$$
C t_{(c)}=F t_{(c)}+b_{(c)}
$$


Após, foi calculado o custo total anual considerando, através dos números obtidos na simulação, a quantidade de navios necessária para o atendimento total da demanda anual.

$$
C t a_{(c)}=C t_{(c)} \cdot y_{(c)}
$$

Durante a simulação, houve resultado de demurrage $(d)$ de US $\$ 790.885,46$ para um ano de operação, e de despatch (e), de US\$2.686.915,36, chegando-se a um custo logístico total anual de US\$163.293.447,31.

$$
C l t(C)=C t a_{(t u)}+\left(C t a_{(c)}+d-e\right)
$$

A tabela 14 apresenta um resumo desta análise para o cenário (C).

\begin{tabular}{|c|c|c|c|c|c|}
\hline \multicolumn{6}{|c|}{ Custo logístico total - operação Capesize com 2 T.U. } \\
\hline \multicolumn{3}{|c|}{ Navio T.U. } & \multicolumn{3}{|c|}{ Navio Capesize } \\
\hline Descrição & Valor & Unidade & Descrição & Valor & Unidade \\
\hline Aluguel T.U. - $t c$ & $25.000,00$ & US\$/dia & Capacidade Cape $-x_{(c)}$ & 160.000 & $\mathrm{t}$ \\
\hline Quantidade T.U.- $t u$ & 2 & & Frete Capesize $-a_{(c)}$ & 13,1 & US\$/t \\
\hline Ciclo do T.U.- $z$ & 1,67 & Dias & Frete total 1 navio $-F t_{(c)}$ & $2.096 .000,00$ & US\$ \\
\hline Custo combustível - bu & $12.819,96$ & US\$ & Custos portuários - $b_{(c)}$ & $26.377,00$ & US\$ \\
\hline Custos portuários - $b$ & $215.676,76$ & US\$ & Total $-C t_{(c)}$ & 2.122.377,00 & US\$ \\
\hline Total $\mathrm{p} / 1$ Capesize $-C t_{(t u)}$ & $540.493,43$ & US\$ & Navios Cape ano - $y_{(c)}$ & 62 & \\
\hline Custo portuário bunker - $b c$ & $91.510,50$ & US\$ & Custo total ano $-C t a_{(c)}$ & $131.587 .374,00$ & US\$ \\
\hline \multirow{3}{*}{ Custo total ano $-C t a_{(t u)}$} & \multirow{3}{*}{33.602 .103} & \multirow{3}{*}{ US\$ } & Demurrage anual - $d$ & $790.885,46$ & US\$ \\
\hline & & & Despatch anual - $e$ & $2.686 .915,36$ & US\$ \\
\hline & & & Custo total ano - $C t a_{(c)}$ & 129.691.344,10 & US\$ \\
\hline \multicolumn{3}{|c|}{ Custo logístico total ano - $C l t(C)$} & $163.293 .447,31$ & & \\
\hline
\end{tabular}

Tabela 14 - Custo logístico total anual - operação de transshipment com 2 T.U. e 1 Capesize

Observa-se que os custos portuários do Capesize são mais baixos devido ao fato de ele não atracar no porto e, consequentemente, não gerar alguns custos relacionados a atracação e desatracação.

Ainda, pelo fato deste cenário não contar com impacto de condições adversas na operação, o valor de economia com despatch ultrapassa o valor de demurrage gerado. 


\subsubsection{Custo logístico para o Cenário (D): transshipment com impacto de condições adversas}

Nesta análise, foram consideradas as mesmas premissas do cenário anterior, porém foi adicionado o custo do impacto de condições climáticas adversas em $25 \%$ do tempo das operações de transshipment.

Neste cenário, o custo do T.U. aumenta devido ao seu maior tempo de ciclo, que é impacto pelas condições adversas. Ainda, o navio Capesize tem seu custo impactado por demurrage ocasionado pelo maior tempo de espera do navios exportadores pelos carregadores.

A tabela 15 apresenta o resultado de custo logístico total anual para o cenário (D), que totalizou US\$165.392.247,08. As fórmulas de cálculo foram as mesmas utilizadas no cenário $(C)$, sendo que somente os valores de cada item que alteraram conforme os cenários.

Tabela 15 - Custo logístico total anual - operação transshipment com $25 \%$ de impacto

\begin{tabular}{|c|c|c|c|c|c|}
\hline \multicolumn{6}{|c|}{ Custo logístico total - operação Capesize com 2 T.U. - 25\% de impacto de condições climáticas } \\
\hline \multicolumn{3}{|c|}{ Navio T.U. } & \multicolumn{3}{|c|}{ Navio Capesize } \\
\hline Descrição & Valor & Unidade & Descrição & Valor & Unidade \\
\hline Aluguel T.U. - tc & $25.000,00$ & US\$/dia & Capacidade Cape $-x_{(c)}$ & 160.000 & t \\
\hline Quantidade T.U.- $t u$ & 2 & & Frete Capesize $-a_{(c)}$ & 13,1 & US $\$ / \mathrm{t}$ \\
\hline Ciclo do T.U.- $z$ & 1,85 & Dias & Frete total 1 navio- $F t_{(c)}$ & $2.096 .000,00$ & US\$ \\
\hline Custo combustível - bu & $14.201,75$ & US\$ & Custos portuários - $b_{(c)}$ & $26.377,00$ & US\$ \\
\hline Custos portuários - $b$ & $215.676,76$ & US\$ & Total $-C t_{(c)}$ & $2.122 .377,00$ & US\$ \\
\hline Total p/ 1 Capesize $-C t_{(t u)}$ & $552.257,01$ & US\$ & Navios Cape ano - $y_{(c)}$ & 62 & \\
\hline \multirow[t]{2}{*}{ Custo portuário bunker - $b c$} & $91.510,50$ & US\$ & Custo total ano $-C t a_{(c)}$ & $131.587 .374,00$ & US\$ \\
\hline & & & Demurrage anual - $d$ & $1.686 .963,11$ & US\$ \\
\hline \multirow[t]{2}{*}{ Custo total ano - $C t a_{(t u)}$} & 34.331 .445 & US\$ & Despatch anual - $e$ & $2.213 .535,40$ & US\$ \\
\hline & & & Custo total ano $-C t a_{(c)}$ & $131.060 .801,71$ & US\$ \\
\hline \multicolumn{3}{|c|}{ Custo logístico total ano - $C l t(C)$} & $165.392 .247,08$ & & \\
\hline
\end{tabular}

\subsubsection{Custo logístico para o cenário (E): transshipment em São Sebastião-SP}

Neste cenário, foram considerados os custos para se realizar a operação de transshipment com 2 T.U.s e 1 Capesize, carregando em Santos-SP e fazendo o transbordo no mar, em águas abrigadas, em São Sebastião-SP. A tabela 16 apresenta um resumo destes custos. As fórmulas de cálculo foram as mesmas 
utilizadas nos cenários anteriores (C) e (D), somente os valores de cada item que alteraram.

O custo dos navios T.U.s é impactado pelo maior tempo de ciclo, devido a distância a ser percorrida entre o porto de Santos-SP e o de São Sebastiao-SP. O custo de combustível, consequentemente, também aumenta, devido ao maior tempo de utilização das embarcações.

Tabela 16 - Custo logístico total anual - operação transshipment em São Sebastião-SP

\begin{tabular}{|c|c|c|c|c|c|}
\hline \multicolumn{6}{|c|}{ Custo logístico total - operação Capesize com 2 T.U. - São Sebastião } \\
\hline \multicolumn{3}{|c|}{ Navio T.U. } & \multicolumn{3}{|c|}{ Navio Capesize } \\
\hline Descrição & Valor & Unidade & Descrição & Valor & Unidade \\
\hline Aluguel T.U. - $t c$ & $25.000,00$ & US\$/dia & Capacidade Cape $-x_{(c)}$ & 160.000 & $\mathrm{t}$ \\
\hline Quantidade T.U.- $t u$ & 2 & & Frete Capesize $-a_{(c)}$ & 13,1 & US $\$ / t$ \\
\hline Ciclo do T.U.- $z$ & 2,58 & Dias & Frete total 1 navio- $F t_{(c)}$ & $2.096 .000,00$ & US\$ \\
\hline Custo combustível - bu & $19.805,68$ & US\$ & Custos portuários - $b_{(c)}$ & $26.377,00$ & US\$ \\
\hline Custos portuários - $b$ & $215.676,76$ & US\$ & Total $-C t_{(c)}$ & $2.122 .377,00$ & US\$ \\
\hline Total p/ 1 Capesize $-C t_{(t u)}$ & $599.964,88$ & US\$ & Navios Cape ano - $y_{(c)}$ & 63 & \\
\hline Custo portuário bunker - $b c$ & $91.510,50$ & US\$ & Custo total ano $-C t a_{(c)}$ & $133.709 .751,00$ & US\$ \\
\hline \multirow{3}{*}{ Custo total ano $-C t a_{(t u)}$} & & & Demurrage anual - $d$ & $18.409 .851,33$ & US\$ \\
\hline & 37.889 .298 & US\$ & Despatch anual - $e$ & $703.863,48$ & US\$ \\
\hline & & & Custo total ano $-C t a_{(c)}$ & $151.415 .738,85$ & US\$ \\
\hline
\end{tabular}

Já para o navio Capesize, o impacto está no valor de demurrage, que chega em 1 (um) ano de operação a US\$18.409.851,33 anuais, devido ao maior tempo de espera do navio exportador pela viagem de carregamento dos T.U.s em Santos e ida à Sebastião-SP para descarga.

\subsection{COMPARATIVO DE CUSTOS DOS CENÁRIOS}

Levantados os custos de todos os sistemas analisados, foram feitos alguns comparativos para se obter o cenário com menor custo logístico total. A figura 31 apresenta um resumo e comparação do custo logístico total das alternativas.

Observa-se que todos os cenários propostos de transshipment analisados apresentam menor custo logístico total anual quando comparados ao cenário 
convencional (A). Entretanto, observando-se somente o menor custo entre as opções, chega-se ao cenário $(\mathrm{C})$, como o de menor custo logístico total.

\section{Custo logístico total anual - US\$}

221.848.662,80

$189.305 .036,74$

$163.293 .447,31$

$165.392 .247,08$
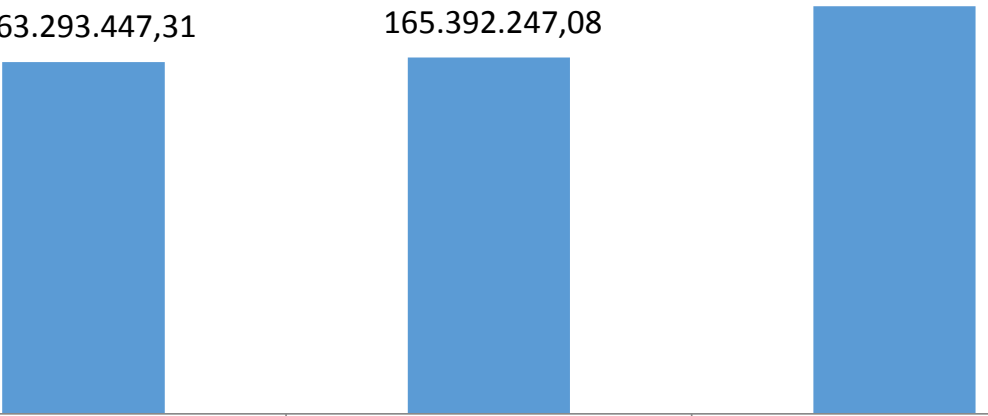

Cenário (C) Capesize + 2 TU Cenário (D) Capesize + 2 TU + Cenário (E) Capesize + 2 TU - Cenário (A) Panamax direto Condições adversas São Sebastião-SP

Figura 31 Resumo do custo logístico total anual dos cenários - US\$

A tabela 17 apresenta o resumo da economia de custo que cada cenário de transshipment apresenta, quando comparado ao cenário de operação convencional.

Tabela 17 - Economia anual de cada cenário comparado à Operação convencional (US\$)

\begin{tabular}{lcccc}
\cline { 2 - 5 } & $\begin{array}{c}\text { Cenário (C) } \\
\text { Capesize + 2 } \\
\text { TU }\end{array}$ & $\begin{array}{c}\text { Cenário (D) } \\
\text { Capesize + 2 TU + } \\
\text { Condições } \\
\text { adversas }\end{array}$ & $\begin{array}{c}\text { Cenário (E) } \\
\text { Capesize + 2 TU - } \\
\text { São Sebastião-SP }\end{array}$ & $\begin{array}{c}\text { Cenário (A) } \\
\text { Panamax direto }\end{array}$ \\
\hline $\begin{array}{l}\text { Economia anual } \\
\text { (US\$) }\end{array}$ & $58.555 .215,49$ & $56.456 .415,72$ & $32.543 .626,06$ & - \\
\hline
\end{tabular}

Por outro lado, o cenário (C) não considera qualquer impacto adverso na operação. Porém, por se tratar uma operação complexa, como visto anteriormente, o embarcador pode optar pelo cenário (D) como referência, caso queira realizar uma análise mais conservadora antes de uma tomada de decisão. Isso porque o cenário (D), mesmo contando com condições adversas, ainda apresenta benefícios em termos de custos logísticos, quando comparado à operação convencional. 
Adicionalmente, levando em consideração que usualmente a operação de transshipment é realizada em águas abrigadas, e que sua realização em Santos-SP pode apresentar resistências dos envolvidos para ser realizada em mar aberto, o embarcador também poderia optar por realizá-la em São Sebastião-SP, já que a região possui mar abrigado e a redução de custos logísticos, ainda que menor, compensa em relação a operação convencional.

\subsubsection{Principais impactos no custo total}

Quando se compara a operação convencional com os principais impactos positivos e negativos da operação de transshipment em São Sebastião-SP, concluise que as principais economias estão relacionadas aos custos portuários e de frete e que os principais impactos negativos estão relacionados ao custo dos T.U.s, ao demurrage e ao menor benefício com despatch.

A figura 32 apresenta as principais economias e os principais custos adicionais para se realizar a operação de transshipment em São Sebastião-SP.

Conclui-se que entre as economias obtidas, 91\% estão relacionadas a redução de custo de frete, já que o frete do navio Capesize é 39\% mais barato que o do Panamax, além do navio ser maior, proporcionando a utilização de menos navios no ano para se transportar o mesmo volume de carga.
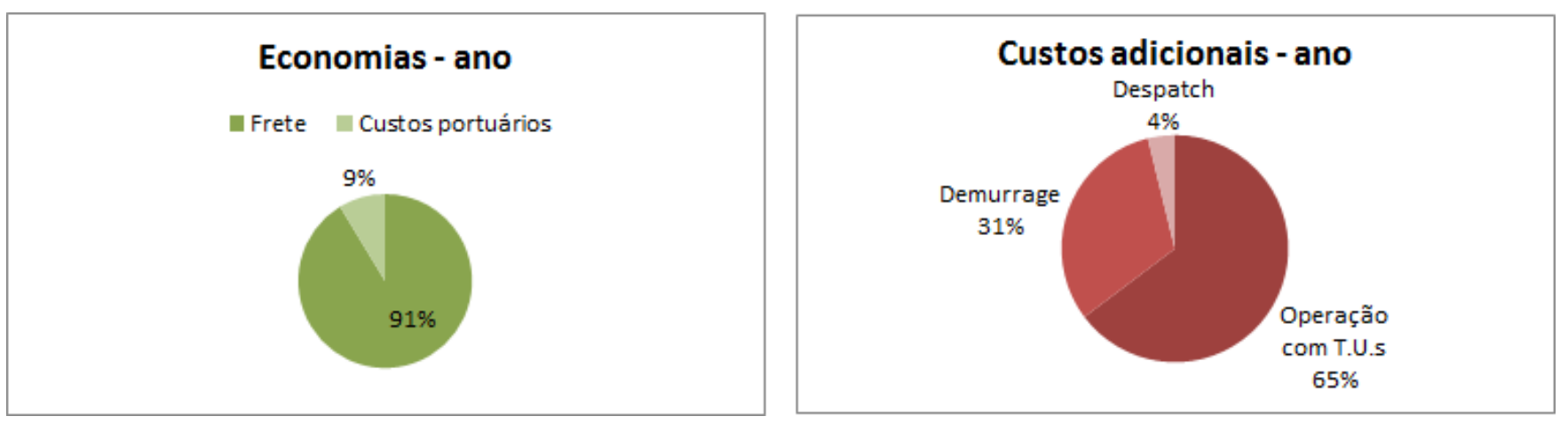

Figura 32 Principais economias e custos adicionais na operação de transshipment

Já a economia em custos portuários se deve ao fato de que o navio ancorado na barra possui menos custos que o convencional, já que ele não é cobrado de alguns valores relacionados a atracação e desatracação em um terminal portuário. 
Em relação aos custos adicionais que a operação de transshipment gera, $65 \%$ do incremento está relacionado à operação com T.U., ou seja, devido ao fato de haver a necessidade de se alugar 2 (dois) navios para se realizar o transbordo da carga, gerando custos antes inexistentes com aluguel dos navios e com combustível.

Logo em seguida, os custos de demurrage representam $31 \%$ do incremento, pois a operação de transshipment possui maior tempo de ciclo quando comparada a convencional, como pôde ser observado nas simulações realizadas.

Por fim, o despatch, ainda que seja sempre um item de economia de custo, quando comparado à operação convencional, apresenta valor menor de ganho, gerando um impacto de $4 \%$ nos custos adicionais.

A figura 33 apresenta um resumo dos custos adicionais (em vermelho) e das economias geradas (em verde) em um ano de operação convencional (à esquerda em cinza) e para a utilização de transshipment em São Sebastião-SP (à direita em cinza). Conclui-se que, entre todos os impactos, o de maior relevância é a economia anual com fretes, que sozinha já supera o valor de todos os custos adicionais somados.

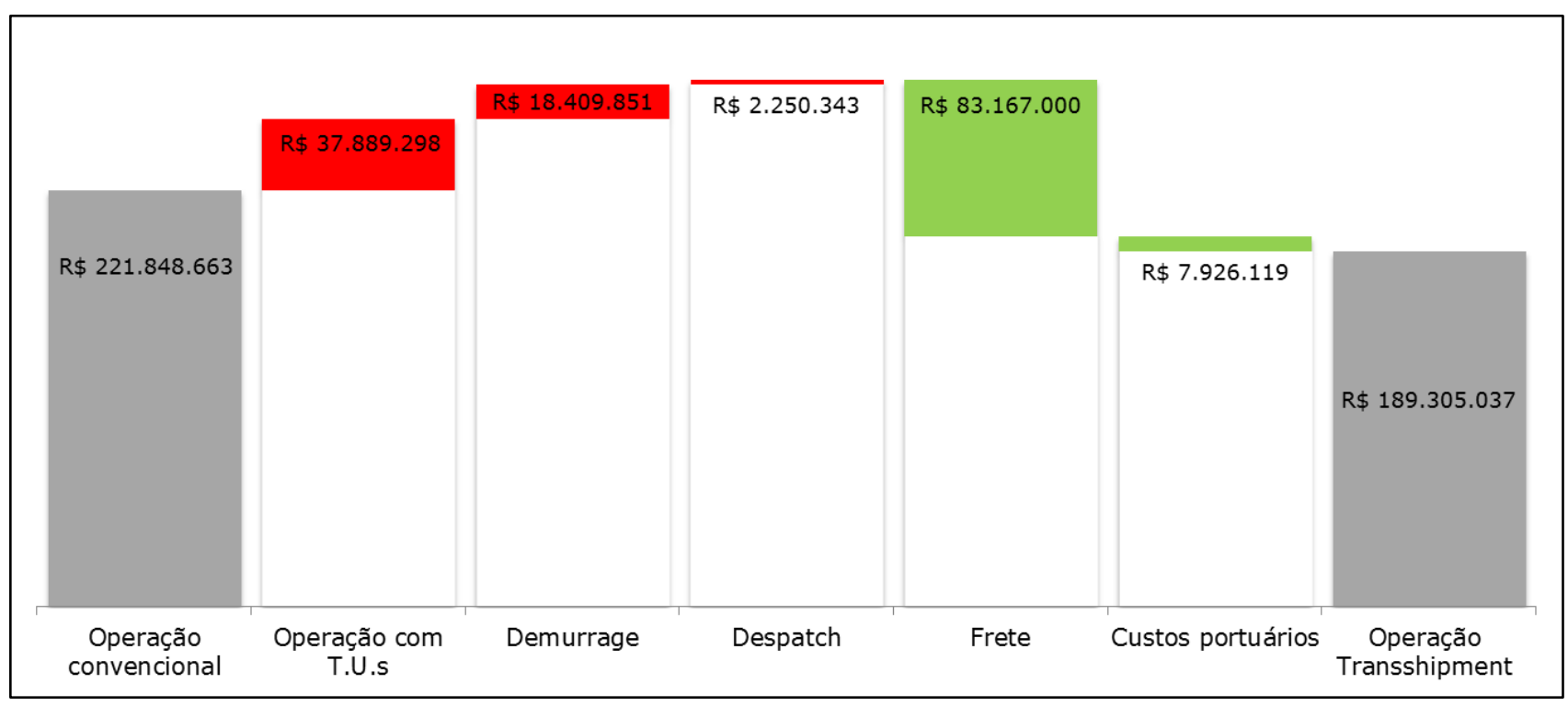

Figura 33 - Resumo dos custos adicionais e das economias anuais da operação de transshipment. 


\subsubsection{Conclusões da análise de custo total}

Através das análises de custos realizadas neste capítulo, é possível concluir que as operações de transshipment apresentaram custo logístico total menor quando comparadas à operação convencional.

Dentre as alternativas, o cenário que apresentou menor custo logístico total foi o (C) Operação de transshipment usando 2 navios da classe Handymax como alimentadores e 1 navio da classe Capesize como principal fundeado em mar aberto em Santos.

Entretanto, este cenário não contempla impactos relacionados a interrupções de operação oriundas de fortes ventos ou swell, por exemplo, situações que, pelo fato da operação ser realizada em mar aberto, ocorrem e, portanto, podem gerar aumento de custos.

Desta forma, sugere-se que o embarcador utilize o cenário (D) Operação de transshipment usando 2 navios da classe Handymax como alimentadores e 1 navio da classe Capesize como principal fundeado em mar aberto em Santos, com impacto de condições climáticas adversas em $25 \%$ do tempo da operação. Desta forma, poderá contemplar em suas análises eventuais impactos que, caso não venham a ocorrer, poderão trazer economias em relação aos custos logísticos esperados.

Por outro lado, tendo em vista que usualmente as operações de transshipment são feitas em águas abrigadas, o embarcador poderia, ainda, optar pelo cenário (E) Operação de transshipment usando 2 navios da classe Handymax como alimentadores e 1 navio da classe Capesize como principal fundeado em mar abrigado em São Sebastião-SP. Isso porque, mesmo se tratando de um local mais afastado de Santos-SP, esse cenário apresentou custos menores em relação à operação convencional, ainda que não no patamar do cenário (D).

Observa-se, ainda, que entre todos os impactos positivos e negativos de custos de se realizar essa operação, o de maior relevância é a economia anual com fretes, que sozinha já supera o valor de todos os custos adicionais somados. Isso se deve ao fato do frete do navio Capesize ser menor em relação ao do Panamax, além de demandar menos navios ao longo do ano, já que o primeiro possui maior capacidade de volume de carga que o segundo. 


\section{CONCLUSÕES E RECOMENDAÇÕES}

Através deste trabalho, foi possível concluir que os navios estão aumentando suas capacidades e, consequentemente, seus tamanhos. Tais mudanças trazem ganhos em fretes mais competitivos, menor consumo de combustível e menor emissão de poluentes. Por outro lado, os navios maiores trazem a necessidade de revisão da infraestrutura portuária, como terminais capacitados para recebê-los e portos com canais com largura e profundidade adequadas.

Visto que as revisões de infraestrutura demandam altos investimentos e que normalmente os portos possuem estruturas antigas, com restrições de expansão, as alterações e investimentos podem se tornar complicados.

No Brasil, há problemas de infraestrutura, tornando difícil a atracação de navios grandes em determinados portos. O porto de Santos, o principal do país, possui profundidade e largura que não comportam as novas embarcações que surgiram.

Uma solução que vem sendo utilizada ao redor do mundo para este problema é o transshipment. A opção do transbordo de carga de navio para navio no mar pode ser uma solução aos problemas de profundidade, falta de capacidade portuária e de altos investimentos.

Este trabalho realizou uma análise operacional e de custos logísticos do processo de transshipment no mar em portos brasileiros. Para tal, realizou um estudo de caso de minério de ferro no porto de Santos-SP.

Para as análises operacionais, foram realizadas simulações de cenários através do método de Simulação no software Arena e realizadas comparações entre operações de transbordo e a operação convencional. $\mathrm{Na}$ análise de custos, foi utilizado o conceito de custo logístico total anual, onde foram levantados todos os valores que envolvem operações desse tipo.

Para tal, inicialmente, foram estudados todos os tipos de transbordo existentes, os principais tipos de navios e equipamentos utilizados nessas operações e as configurações de atracação que podem ser realizadas. 
Em seguida, foi realizada uma revisão de literatura, onde foram apresentados os estudos existentes relacionados ao tema no mundo e no Brasil. Nesta etapa, a autora relatou os esforços e a dificuldade de encontrar estudos relacionados, concluindo ter sido o tema ainda pouco estudado, sendo necessário refinar as palavras chaves por diversas vezes para obter melhores resultados.

Foram pesquisadas também as legislações relacionadas ao tema no Brasil e no exterior e os principais orgãos e entidades que regulamentam esse tipo de operação no mundo.

Na definição do caso, foi escolhido o porto de Santos-SP para a análise por ser o principal do país e possuir restrições de profundidade para receber navios maiores. O problema escolhido foi o de minério de ferro para exportação, pelo fato da mina produtora localizada em Corumbá-MS não possuir solução logística ideal e o estado do Mato Grosso do Sul estar na região de influência do Porto de SantosSP.

No intuito de se avaliar o problema do transshipment e suas alternativas de decisão, foram feitos os modelos conceituais tanto do processo convencional de operação de exportação de minério, quanto o de transshipment no porto de Santos. A partir dos modelos, foram avaliados os métodos científicos existentes para aplicação e, dada as características do problema, foi selecionado o modelo de simulação computacional para a realização da análise e obtenção dos resultados, utilizando o software Arena.

A simulação foi escolhida pois havia a necessidade se analisar um sistema existente, bem como um novo, com a utilização de transbordo, operação que possui grau de incerteza.

Através das simulações e análises de sensibilidade realizadas, foi possível concluir que o cenário inicial de transshipment com 1 carregador, apesar de atender a demanda parcialemente, deixava o navio exportador por um longo período de espera na barra em Santos. Isso posto, o cenário de utilização de 2 carregadores T.U.s se tornou mais adequado, por atender de forma mais rápida a carga e descarga e reduzir o tempo de espera dos navios OGV.

Entretanto, pelo fato da barra do porto de Santos-SP ser um local de mar aberto, o sistema poderia sofrer interrupções ocasionadas por condições adversas, como por exemplo, forte swell. Sendo assim, foram feitas simulações com impactos 
em $25 \%, 50 \%$ e $75 \%$ do tempo de operação, observando-se que ainda assim o sistema conseguia atender a demanda, porém, nos dois ultimos cenários, o tempo de espera dos navios aumentava substancialmente.

Quando foi analisada a possibilidade de se realizar a operação de transshipment em mar abrigado, como no caso da carga saindo do terminal em Santos-SP para a realização do transbordo no mar do porto de São Sebastião-SP, foi possível concluir pelas simulações que o sistema conseguia atender a demanda, porém, o tempo do ciclo do navio T.U. aumentava consideravelmente.

Para entender se os aumentos nos tempos de espera dos navios exportadores e do ciclo do T.U. impactavam de tal forma a inviabilizar a operação, foi realizada, por fim, uma análise dos custos logísticos anuais das alternativas, de forma a se chegar ao melhor cenário.

As análises de custos foram realizadas sob o ponto de vista do embarcador da mercadoria, levantando-se os principais custos logísticos existentes, como fretes, aluguel de navio carregador, combustível e demurrage.

Através das análises, foi possível concluir que as operações de transshipment apresentaram custo logístico total menor quando comparadas à operação convencional.

Dentre as alternativas, o cenário que apresentou menor custo logístico total foi o (C) Operação de transshipment usando 2 navios da classe Handymax como alimentadores e 1 navio da classe Capesize como principal fundeado em mar aberto em Santos. Porém, este cenário não contemplou impactos relacionados a interrupções de operação oriundas de fortes ventos ou swell, por exemplo, situações estas que podem gerar aumento de custos.

Com isso, sugeriu-se que o embarcador utilizasse o cenário (D) Operação de transshipment usando 2 navios da classe Handymax como alimentadores e 1 navio da classe Capesize como principal fundeado em mar aberto em Santos, com impacto de condições climáticas adversas em $25 \%$ do tempo da operação. Desta maneira, ele poderia contemplar em suas análises eventuais impactos em suas operações.

Entretanto, a autora sugere que, tendo em vista que usualmente as operações de transshipment são feitas em águas abrigadas, o embarcador opte pelo cenário (E) Operação de transshipment usando 2 navios da classe Handymax como 
alimentadores e 1 navio da classe Capesize como principal fundeado em mar abrigado em São Sebastião-SP. Isso porque, mesmo se tratando de um local mais afastado de Santos-SP, esse cenário apresentou custos menores em relação a operação convencional (US\$ 189.305.036,74 contra US\$221.848.662,80 da operação convencional), ainda que não nos patamares dos cenários anteriores.

Reforça-se também que, entre os principais impactos de custos de se realizar essa operação, o de maior relevância é a economia anual com fretes marítimos, que sozinha já supera o valor de todos os custos adicionais somados. Isso se deve ao fato do frete do navio Capesize ser inferior ao do Panamax, além de demandar menos navios ao longo do ano, já que o primeiro possui capacidade de carga bastante superior.

Para finalizar, a autora enfatiza que, para futuros trabalhos e projetos, seja aprofundado o tema da legislação, inclusive de mão de obra do navio, e das licenças necessárias para se realizar a operação no Brasil. Isso porque, durante a pesquisa e entrevistas realizadas sobre o assunto, foi verificado que um entrave para se realizar uma operação do tipo no país atualmente está relacionado às permissões para se realizá-la.

Segundo as fontes, isso ocorre pois não há uma legislação que verse sobre o tema e diferentes órgãos possuem funções similares para tratar o assunto, podendo trazer demoras às liberações. Adicionalmente, pelo fato do transbordo ser uma operação de maior complexidade, as entidades de praticagem podem apresentar resistência, alegando ser a operação insegura e inadequada. Há que se romper algumas barreiras para se realizar uma operação desse tipo.

Ainda, como próximo passo, as empresas ou entidades que possuam interesse na operação, devem realizar uma análise econômico-financeira para que possam obter projeções e resultados dessa operação a longo prazo.

A autora conclui que seu método mostrou que pode ser aplicado não só em casos de operações de minérios em portos de baixo calado, como também para demais tipos de cargas e portos, principalmente no Brasil, que possui um maior potencial para que essa operação seja explorada.

O estudo poderia ser aplicado inclusive a outro commodity importante para o país, como a soja ou o açúcar e, para aplicação em cargas com maior sazonalidade, poderia ser analisada a opção de se utilizar navios parciais, ou seja, utilizar uma 
embarcação somente para um período de pico, ou um navio aliviado ou compartilhado com outras cargas, o que poderia baratear a operação e atender melhor a demanda. Há, adicionalmente, como se explorar o modelo para utilização em operações de contêineres.

A autora conclui ainda que a metodologia se provou válida até mesmo para extrapolações e aplicações em casos internacionais ou estudos de caso fora do Brasil, podendo ser explorada e adaptada através dos modelos de simulação e custos que foram levantados neste trabalho. 


\section{REFERÊNCIAS}

ANGLO AMERICAN Saída para o mundo: portos da Anglo são diferenciais competitivos da empresa no Mercado. Revista Conexão Anglo, Número 002, Ano 01. Disponível em: <http://brasil.angloamerican.com/ /media/Files/A/AngloAmerican-Brazil/Attachments/pdf/mineirio-ferro-conexao-anglo-jornal-edicao-02setembro-2009-parabens.pdf> Acesso em 01 Set 2015.

ANTAQ Porto de Areia Branca ou porto de sal. Disponível em < http://www.antaq.gov.br/portal/pdf/Portos/AreiaBranca.pdf>. Acesso em 12 Out 2015.

ANTAQ Estação de Transbordo de Carga. Disponível em http://www.antaq.gov.br/Portal/pdfSistema/publicacao/0000002110.pdf. Acesso em 24 Jan 2016.

ANTAQ Anuário Estatístico Aquaviário - 2016. Disponível em <http://portal.antaq.gov.br/index. php/estatisticas/>. Acesso em 14 Jun 2017.

BAIRD, A.J.; ROTHER, D. Technical and economic evaluation of the floating container storage and transshipment terminal (FCSTT). Transportation Research part C: Emerging Technologies. Elsevier, 2012. Disponível em: < http://www.sciencedirect.com/science/article/pii/S0968090X13000028>. Acesso em 21 Set 2015

BALLOU, R.H. Gerenciamento da cadeia de suprimentos / Logística empresarial, p. 57 a 59 5ª edição, Editora Bookman, 2006.

BANKS, J.; CARSON II, J.S.; NELSON, B.L.; NICOL, D.M.; Discrete-event system simulation. p. 9 a 11, 4ª edição, Editora Pearson, 2005.

BERTOLOTO, L.P. Modelo de previsão de frete marítimo de minério de ferro utilizando redes neurais artificiais. Dissertação de Mestrado, UFF, 2010. Disponível em http://www.dominiopublico.gov.br/download/texto/cp130243.pdf Acesso em 06 Fev 2017.

BNDES Insumos básicos - minério de ferro Disponível em < http://www.bndes.gov.br/SiteBNDES/export/sites/default/bndes pt/Galerias/Arquivos/ conhecimento/bnset/set3906.pdf> Acesso em 07 Nov 2015.

BOTTER, R.C. Tratamento de dados em simulação discreta. Tese (LivreDocência) Poli - USP, Depto. De Engenharia Naval e Oceânica, São Paulo-SP, 2002.

BOWERSOX, D.J.; CLOSS, D.J. Logistical Management: The Integrated Supply Chain Process, Editora McGraw-Hill, Estados Unidos da América, 1996.

BOWERSOX, D.J.; CLOSS, D.J.; COOPER, M.B. Supply Chain Logistics Management, 4ª edição, Editora McGraw-Hill, Estados Unidos da América, 2011.

BROWN, M. Exploration and Resource Definition of Offshore Titan-Magnetite Iron Sands, on the West Coast of New Zealand. Offshore Technology Conference, 
Houston, 2013. Disponível em: < https://www.onepetro.org/conference-paper/OTC24038-MS $>$. Acesso em 21 Set 2015.

BUCKLEY, P.; LEE, K.; KUBY, M. Evaluating dredging and offshore loading locations for U.S. coal exports using the local logistics system. Annals of Operations Research 6, 1986 p. 163-180.

CAMBRIGDE. Definição do termo transshipment. Disponível em: < http://dictionary.cambridge.org/pt/dicionario/ingles/transshipment?fallbackFrom=engli sh-portuguese>. Acesso em 21 Dez 2015.

CASTRO, S.; ALMEIDA, J. Dragagem e conflitos ambientais em portos clássicos e modernos: uma revisão. Soc. \& Nat., Uberlândia, ano 24 n.3, 519-534, set-dez 2012.

CHWIF, L., MEDINA, A.C. Modelagem e Simulação de Eventos Discretos: Teoria \& Prática, 2ª edição. São Paulo, 2007.

CIGOLINI, R.; ROSSI, T. Sizing off-shore transshipment systems in dry-bulk transportation. Production Planning and Control, Taylor \& Francis, 2010. Disponível em: < http://www.tandfonline.com/doi/abs/10.1080/09537280903514587>. Acesso em 22 Set 2015.

CIGOLINI, R.; PERO M.; ROSSI, T. Sizing off-shore transshipment systems: a case study in maritime dry bulk transportation. Production Planning and Control, Taylor \& Francis, 2011. Disponível em: < http://www.tandfonline.com/doi/abs/10.1080/09537287.2011.598266>. Acesso em 22 Set 2015.

CODESP Panorama do Porto de Santos. Disponível em < http://www.portodesantos.com.br /down/imprensa/panorama porto.pdf> Acesso em 06 Fev 2016. Santos, 2015.

DAZIBAO Estação flutuante de transbordo de cargas. Pinheiro Pedro Advogados. Disponível em http://www.dazibao.com.br/site/estacao-flutuante-de-transbordo-decargas/. Acesso em 25 Fev 2016

HONG KONG SAR GOVERNMENT. Transshipment Best Practices- Hong Kong Experience. Gulf Cooperation Council Counter proliferation Workshop Dubai, UAE, $2012 . \quad$ Disponível em: < https://www.state.gov/strategictrade/documents/organization/190335.pdf>. Acesso em 22 Set 2015.

IBRAM 0 minério de ferro. Disponível em < http://www.simineral.org.br/arquivos/Ferro\%20-\%20IBRAM.pdf> Acesso em $12 \mathrm{Nov}$ 2015.

INTERNATIONAL TRANSPORT FORUM. The impact of Mega Ships. Paris, 2015. Disponível em: < www.internationaltransportforum.org >. Acesso em 01 Nov 2015.

IPEA Gargalos e demandas da infraestrutura portuária e os investimentos do PAC: mapeamento IPEA de obras portuárias. Brasília, 2009. 
KEEDI, S. ABC do Comércio Exterior: abrindo as primeiras páginas. 4. ed. São Paulo: Aduaneiras, 2011.

KURT, I.; BOULOUGOURIS, E.; TURAN, O. Cost based analysis of the offshore port system. International Conference on Ocean, Offshore and Arctic Engineering. Newfoundland, $\quad$ Canada, 2015. Disponível em: < http://www.researchgate.net/publication/277934030>>. Acesso em: 29 Set 2015.

LIANG, C.; HWANG, H.; GEN, M. A berth allocation planning problem with direct transshipment consideration. Journal of Intelligent Manufacturing, Springer US, 2011. Disponível em: < http://link.springer.com/article/10.1007\%2Fs10845-011-05669> Acesso em 26 Dez 2015.

MAGALHÃES, P. Transporte Marítimo: cargas, navios, portos e terminais. São Paulo: 2007

MENDONÇA, PAULO C.C.; KEEDI, S. Transportes e Seguros no Comércio Exterior. Editora Aduaneiras, 1997.

MMA Guia de Procedimentos do Licenciamento Ambiental Federal Disponível em < http://www.mma.gov.br/estruturas/sqa pnla/ arquivos/Procedimentos.pdf >. Acesso em 27 Jan 2016.

OLDENDORFF Transbordo de minério brasileiro em Trinidad. Disponível em: < http://www.oldendorff.com/reloaders/Trinidad.html>. Acesso em 09 Jan 2016.

PDEPS Plano de desenvolvimento e expansão do porto de Santos. Relatório Preliminar Consolidado. Santos: CODESP, 2009.

PETROBRAS MARINE Bunker Daily Report. Disponível em < http://www.petrobras.com.br/en/products-and-services/products/maritime/bunker/>.

Acesso em 23 Fev 2017.

PLATTS Índice de fretes marítimos Disponível em: <https://www.platts.com/IM.Platts.Content/ProductsServices/Products/dry-freightwire.pdf>. Acesso em 23 Fev 2017.

PORTOS E NAVIOS Porto de Santos é principal zona portuária da América Latina Disponível em $<$ https://www.portosenavios.com.br/noticias/portos-elogistica/32451-porto-de-santos-e-principal-zona-portuaria-da-america-latina>

Acesso em 06 Fev 2016.

PORT TECHNOLOGY Berth productivity will have to keep up with shipping's super-sized revolution. Maersk Line, 50a Edição, p. 18-20, Denmark, 2012.

SECRETARIA DA RECEITA FEDERAL Transbordo e baldeação. Disponível em: $<$ http://idg.receita.fazenda.gov.br/orientacao/aduaneira/manuais/transito-

aduaneiro/topicos/controle-do-regime/transbordo-e-baldeacao> Acesso em: 24 Jan 2015.

SILVA, R.C.S.; BOTTER, R.C; TREVISAN, E.F.C; MEDINA, A.C.; PEREIRA, N.N.; NETTO, J.F. Planejamento de um Sistema de Transshipment para a exportação de carvão utilizando Simulação de eventos discretos. USP, São Paulo, 2009. 
Disponível

em:

http://www.ipinamericas.org/sites/ba viejo/downloads/XXI/066 BOTTER RUI CARL OS.pdf > Acesso em 19 Set 2015.

SOUZA, C. E. S. Modelagem e análise de duas alternativas para operações de transferência de petróleo entre dois navios em alto-mar. Dissertação de Mestrado, USP, 2012. Disponível em: < http://www.teses.usp.br/teses/disponiveis/3/3135/tde-21062013-110538/pt-br.php>.

Acesso em: 18 Set 2015.

TEIXEIRA, V. B. Operações de transbordo de petróleo nacional na baía de Ilha Grande. Dissertação de Mestrado UFRJ, 2011. Disponível em: < http://www.oceanica.ufri.br/intranet/teses/2011 mestrado vinicius barros teixeira.pd f>. Acesso em 05 Jan 2016.

US LEGAL Transshipment Law and Legal Definition. Disponível em http://definitions.uslegal.com/t/transshipment/. Acesso em 09 Jan 2016.

WANG, Y. Operability study of floating bulk transshipment operation. Delft University of Technology, 2015. Disponível em: < http://repository.tudelft.nl/view/ir/uuid: 6ff67b1f-adf7-4435-9600-7d29ce0c5147/ > Acesso em 22 Set 2015.

WIKIPEDIA Terminal Salineiro de Areia Branca - RN. Disponível em: < https://pt.wikipedia.org/wiki/Terminal Salineiro de Areia Branca>. Acesso em 15 Out 2015.

WINSTON, W.L. Operations Research - Applications and Algorithms. 1a Edição, Indiana, Estados Unidos da América, 1994.

VALE. FTS - Floating Transshipment System. Disponível em http://www.vale.com. Acesso em 13 Ago 2015.

VALOR ECONOMICO Codesp planeja porto do futuro para nova geração de navios. Disponível em < http://www.valor.com.br/empresas/transporte $>$ Acesso em 19 Jan 2016.

VETRIA Projeto Integrado Disponível em: < http://vetorial.ind.br/_arquivos/diversos/apresenta-o-consolidada-vetria.pdf> Acesso em 01 Set 2015 


\section{APÊNDICE A - ENTREVISTA COM PROFISSIONAL DE CORRETAGEM DE NAVIOS}

Entrevista concedida verbalmente em 07 de novembro de 2016.

AUTORA: "Você já recebeu alguma solicitação de empresa para realizar uma operação de transshipment no Brasil"?

ENTREVISTADO: "Trabalhei no projeto de uma empresa que importava carvão. Eles viram o benefício de frete se usassem navios maiores e pediram para fazermos um teste no porto de São Sebastião-SP".

AUTORA: "A operação foi bem sucedida"?

ENTREVISTADO: "Foi sim, mas teve que ser interrompida depois por conta das dificuldades de adequação da tripulação do navio, que por exigência da Praticagem, deveriam ser de nacionalidade brasileira. A demanda da empresa caiu bastante também, acabando inviabilizando a operação".

AUTORA: "Qual sua opinião sobre a viabilidade do transshipment no Brasil"?

ENTREVISTADO: "Olha, é viável sim. Vários países já fazem. Eu soube de colegas que tentaram realizar a operação em Itaguaí-RJ. $O$ grande entrave são as burocracias de aprovações, a questão da tripulação que eu te comentei".

AUTORA: "Você entende que ela é viável no porto de Santos-SP"?

ENTREVISTADO: "A região da barra de Santos-SP tem o mar muito mexido, com swell. Eu acho que a Praticagem não aceitaria, não sei. Essas operações o ideal é realizar e águas abrigadas".

AUTORA: "Supondo que essa operação fosse realizada em Santos, mesmo com impactos de condições ruins, em quanto (\%) do tempo da operação, você entende que poderia haver paradas"?

ENTREVISTADO: "Eu acho que em uns $25 \%$ do tempo da operação haveria impactos, tendo que parar o transbordo e aguardar condições melhores".

AUTORA: "Qual sua opinião sobre o modelo de transshipment simulado no trabalho de 1 Handymax carregando 1 Capesize"?

ENTREVISTADO: "Normalmente essas operações usam 2 navios, ou 1 navio maior, como o Panamax, se o porto der condição. Sugiro fazer com 2 Handymax".

AUTORA: "Você tem alguma sugestão adicional para este trabalho"?

ENTREVISTADO: "Eu sugiro você simular o transbordo saindo de Santos-SP e sendo feito em São Sebastião-SP. Lá o mar é abrigado e a operação pode render melhor, além de haver rota de navios de carvão, de repente até reduz o frete do Capesize". 


\section{APÊNDICE B - MODELO DO ARENA}

MODELO TOTAL

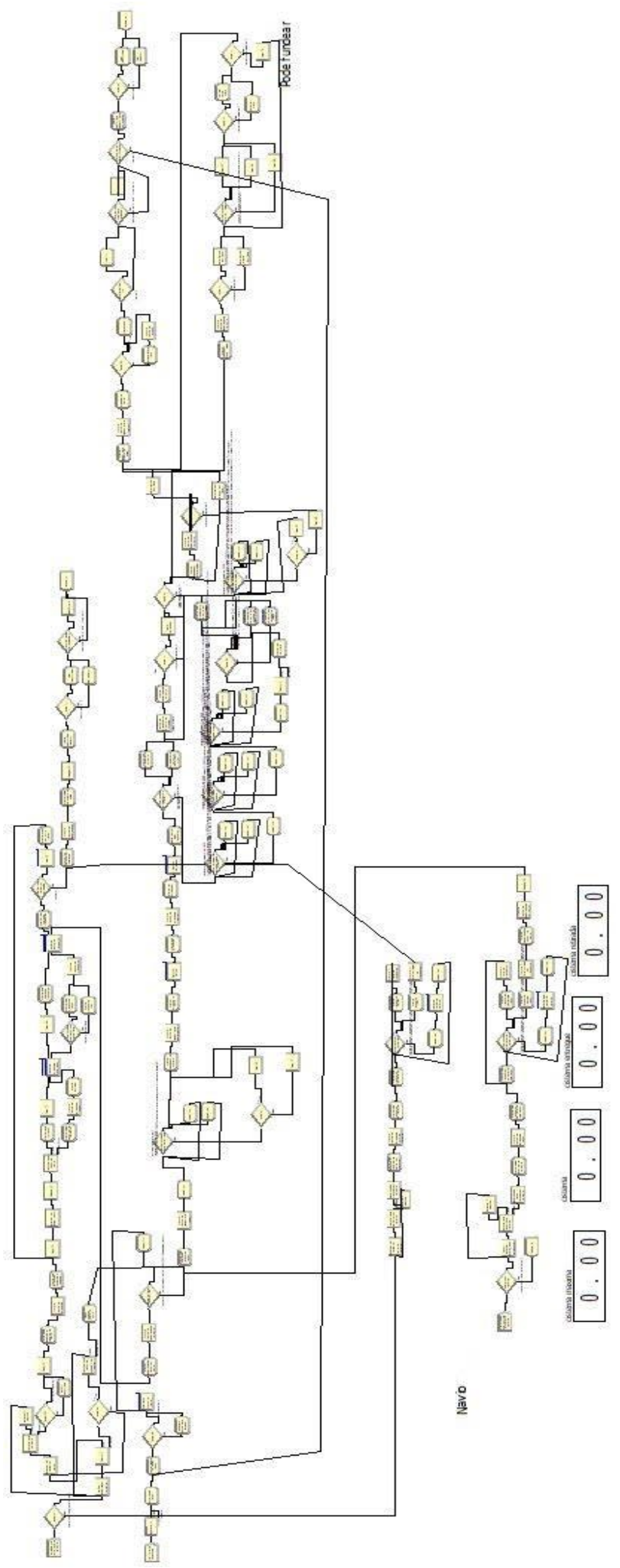


AMPLIAÇÃO: ETAPAS PRINCIPAIS - OPERAÇÃO DOS NAVIOS T.U. E OGV:

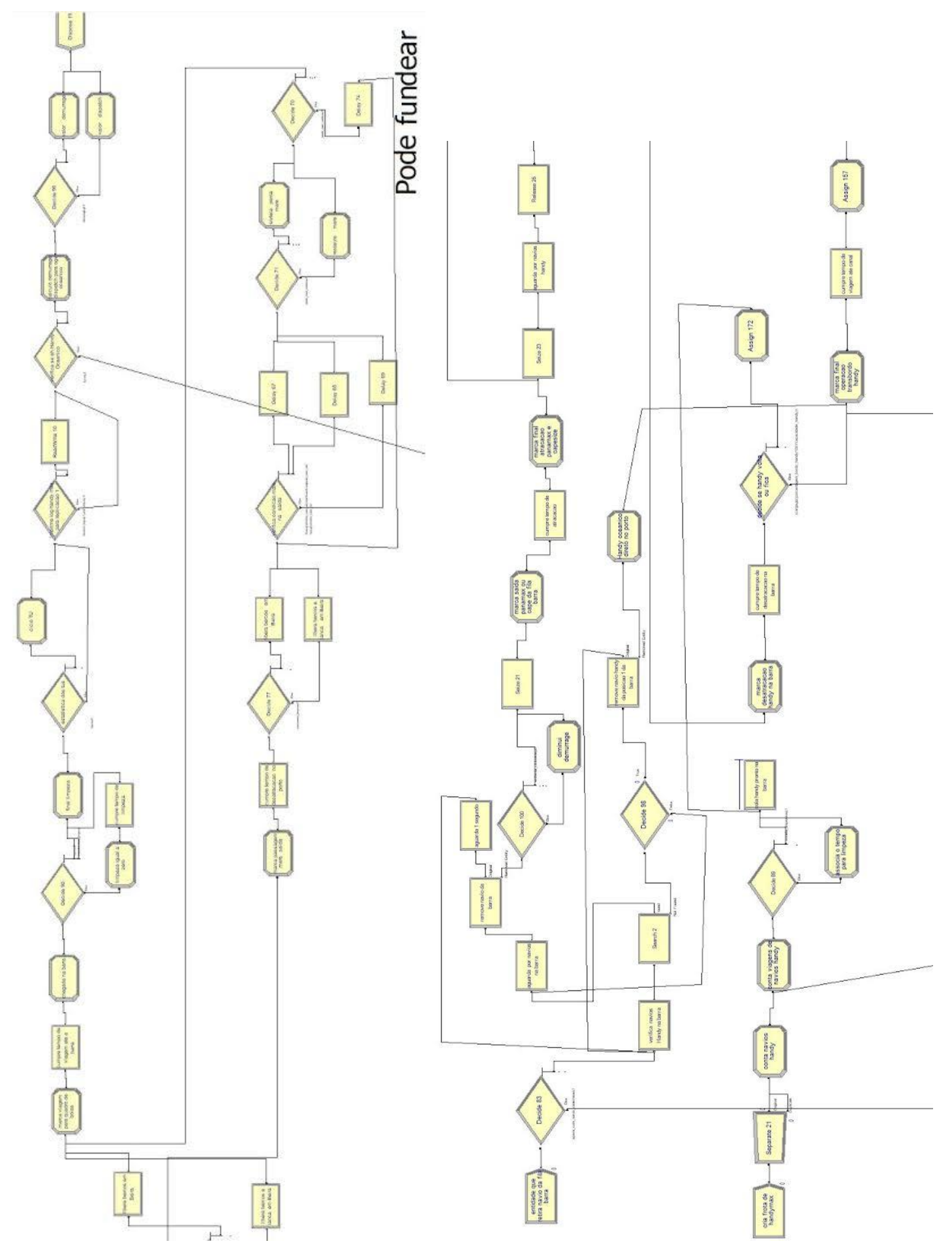




\section{APÊNDICE C - RESULTADOS DE SAÍDA DO MODELO DO ARENA}

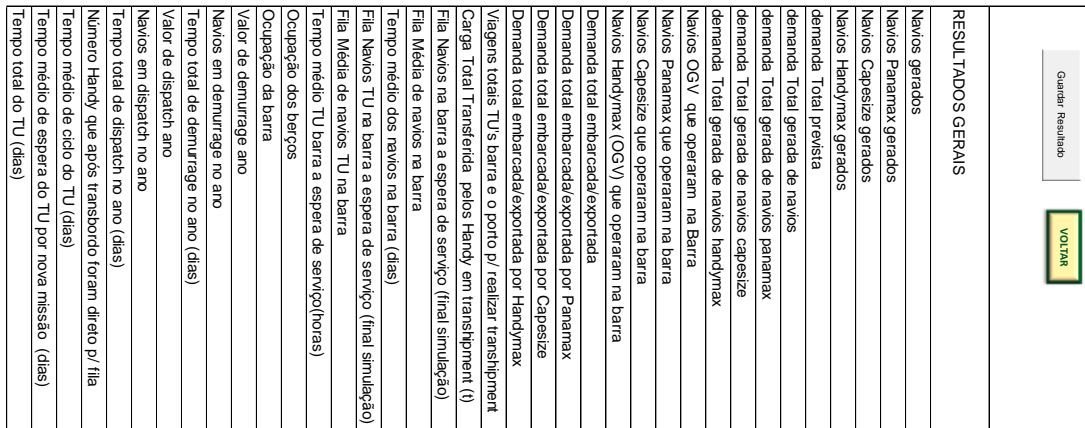

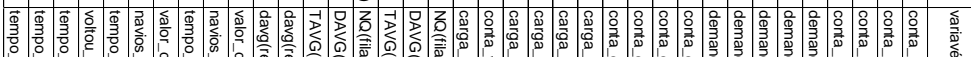

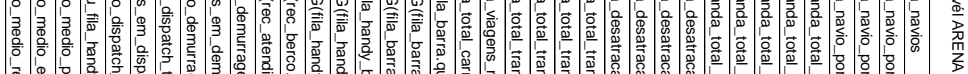

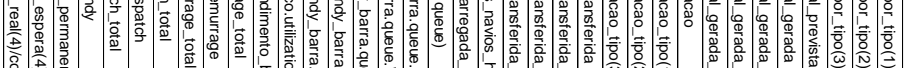

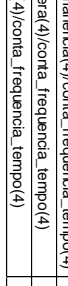
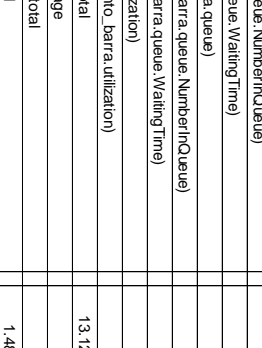

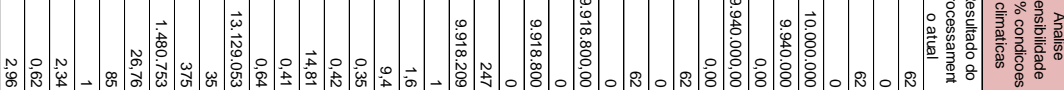

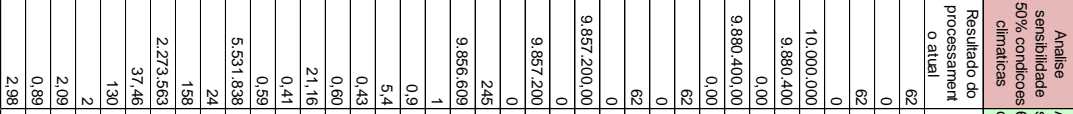

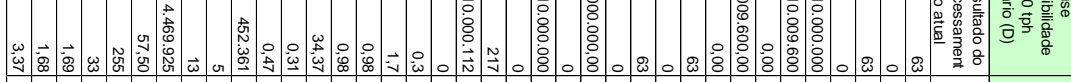

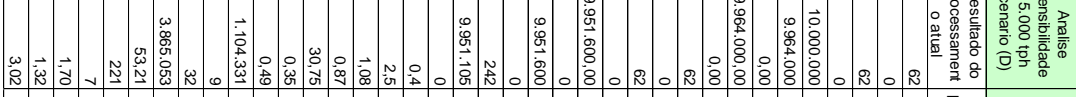

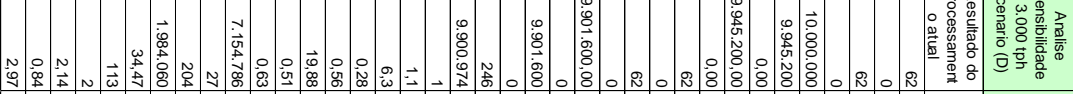

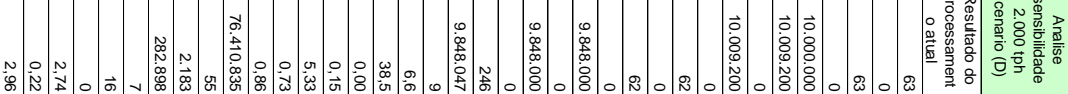

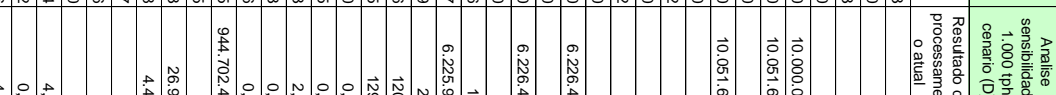

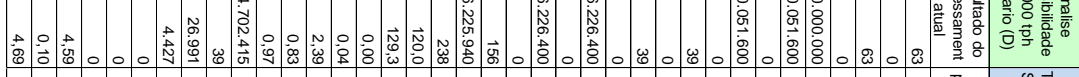

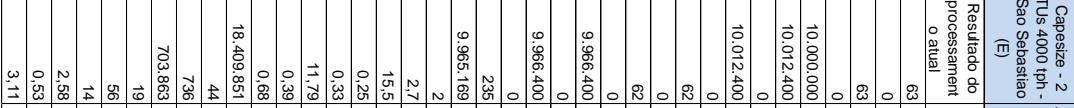

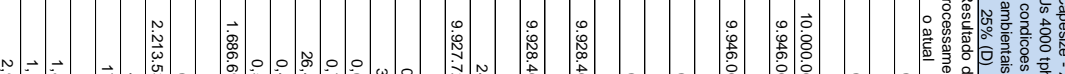

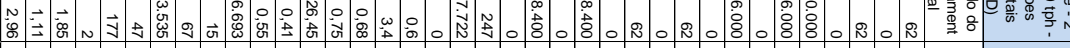

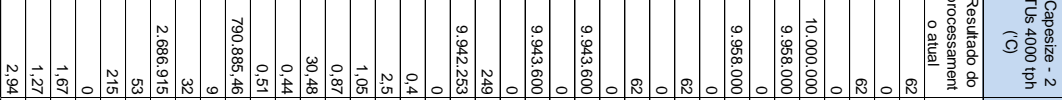

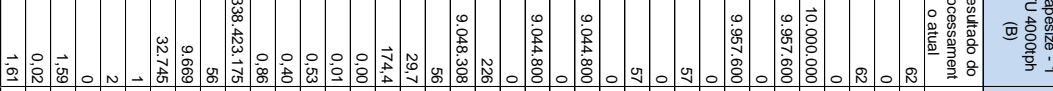

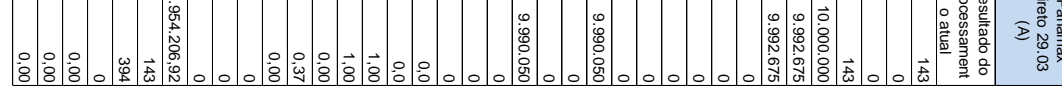




\section{ANEXO A - DESCRIÇÕES DE DESPESAS PORTUÁRIAS}

\begin{tabular}{|c|c|c|}
\hline Despesa portuária & Tradução & Descrição \\
\hline Light dues & Taxa de Farol & $\begin{array}{l}\text { Taxa paga a Marinha do Brasil para manutenção } \\
\text { dos Faróis na costa. }\end{array}$ \\
\hline $\begin{array}{l}\text { Funapol - Federal } \\
\text { Police }\end{array}$ & $\begin{array}{l}\text { Fundo para Polícia } \\
\text { Federal }\end{array}$ & $\begin{array}{l}\text { Taxa cobrada para Polícia Federal proceder à } \\
\text { fiscalização de embarcações em viagem de } \\
\text { curso internacional. }\end{array}$ \\
\hline Clearance & Liberação aduaneira & $\begin{array}{l}\text { Custo de liberação aduaneira, envolvendo } \\
\text { Alfândega, Polícia Federal e Saúde dos portos. }\end{array}$ \\
\hline Pilotage in/out & $\begin{array}{l}\text { Praticagem entrada e } \\
\text { saída }\end{array}$ & $\begin{array}{l}\text { Serviços cobrados de Praticagem para } \\
\text { atracação/ desatracação do navio. }\end{array}$ \\
\hline Pilotage for anchoring & Praticagem de fundeio & $\begin{array}{l}\text { Serviços cobrados pela Praticagem para trazer o } \\
\text { navio até o fundeio. }\end{array}$ \\
\hline Towage & Rebocadores & Servicos de rebocagem para entrar/sair do porto. \\
\hline Watchmen & Vigia de bordo & Vigia compulsório para ficar na escada do navio. \\
\hline Channel dues & Taxas de Canal & Cobrança para se passar no canal portuário. \\
\hline Wharfage & Capatazia & Cobrança de uso do cais do porto. \\
\hline Launch hire & Lancha & $\begin{array}{l}\text { Serviço de lancha para levar vigia, agentes, } \\
\text { autoridades à bordo quando o navio está } \\
\text { fundeado. }\end{array}$ \\
\hline Car hire & Carro & $\begin{array}{l}\text { Serviços de transporte ao navio e/ou porto } \\
\text { quando atracado. }\end{array}$ \\
\hline $\begin{array}{l}\text { Communication / } \\
\text { postage }\end{array}$ & $\begin{array}{l}\text { Comunicação / } \\
\text { postagens }\end{array}$ & Custos com comunicação e postagem. \\
\hline Agency fee & Taxa da Agência & Serviços de agenciamento. \\
\hline Municipal tax & Taxa Municipal & Taxa municipal. \\
\hline IOF & IOF & IOF. \\
\hline $\begin{array}{l}\text { Port State Control } \\
\text { Survey }\end{array}$ & Controle Portuário & Taxa de controle portuário. \\
\hline Certificates expenses & $\begin{array}{l}\text { Despesas com } \\
\text { certificados }\end{array}$ & Despesa para emissão de certificado da carga. \\
\hline $\begin{array}{l}\text { Ship owners tax - } \\
\text { Sindamar }\end{array}$ & Taxa do Sindicato & Taxa de Sindicato local. \\
\hline
\end{tabular}




\section{ANEXO B: BUNKER DAILY REPORT - PETROBRAS MARINE}

BUNKER DAILY REPORT

Dear Customer,

Please find below price indication ranges of marine fuels practiced by Petrobras Marine for the following Brazllan, and Uruguayan ports. Prices may change any time during the day and all products avaliablity must be conflmed before nominated.

23.2.2017 INDICATION RANGES Prices valld after 22:00h (Brasllla TIme)

\begin{tabular}{|c|c|c|c|c|c|c|c|c|c|}
\hline \multirow{3}{*}{\begin{tabular}{|c|} 
PORTS \\
BELEM-PA \\
\end{tabular}} & \multirow{2}{*}{\multicolumn{3}{|c|}{ IFO $380 \mathrm{CST}$}} & \multirow{2}{*}{\multicolumn{3}{|c|}{ IFO $180 \mathrm{CST}$}} & \multirow{2}{*}{\multicolumn{3}{|c|}{ AUI pricas in USDIM }} \\
\hline & & & & & & & & & \\
\hline & 386,00 & - & 387.00 & 417,50 & - & 418,50 & 761,50 & & 762,50 \\
\hline MACEIO-AL & \multicolumn{3}{|c|}{$\mathrm{mat}$} & \multicolumn{3}{|c|}{$m$} & 713,50 & pDe & 714,50 \\
\hline FORTALEZA-CE & 373,00 & & 374,00 & & & & 737,50 & PDE & 738,50 \\
\hline \multicolumn{10}{|l|}{ ITAQUI-MA (barge) } \\
\hline ITAQUI-MA (plpe) & & & & & & & 755,50 & PADE & 756,50 \\
\hline MANAUS-AM & \multicolumn{3}{|c|}{$\mathrm{Mn}$} & 397,00 & - & 398,00 & 725,50 & & 726,50 \\
\hline NITEROI-RJ & 322,00 & - & 323,00 & 353,50 & - & 354,50 & 701,50 & & 702,50 \\
\hline PARANAGUA-PR & 332,00 & - & 333,00 & 363,50 & - & 364,50 & 747,50 & & 748,50 \\
\hline PRAIA MOLE-ES & 332,00 & - & 333,00 & 363,50 & - & 364,50 & 737,50 & & 738,50 \\
\hline \multicolumn{10}{|l|}{ RECIFE-PE } \\
\hline RIO DE JANEIRO-RJ & 322,00 & - & 323,00 & 353,50 & - & 354,50 & 701,50 & & 702,50 \\
\hline RIO GRANDE-RS & 332,00 & - & 333,00 & 363,50 & - & 364,50 & 748,50 & & 749,50 \\
\hline SALVADOR-BA & 360,00 & - & 361,00 & 391,50 & - & 392,50 & 729,50 & & 730,50 \\
\hline SANTOS-SP & 317,00 & - & 318,00 & 348,50 & - & 349,50 & 714,50 & & 715,50 \\
\hline \multicolumn{10}{|l|}{ SUAPE-PE (PIPE) } \\
\hline \multicolumn{10}{|l|}{ SUAPE-PE (BARGE) } \\
\hline TUBARAO-ES & 332,00 & - & 333,00 & 363,50 & - & 364,50 & 737,50 & & 738,50 \\
\hline VILA DO CONDE-PA & 386,00 & - & 387,00 & 417,50 & - & 418,50 & 761,50 & & 762,50 \\
\hline VITORIA-ES & 332,00 & - & 333,00 & 363,50 & - & 364,50 & 737,50 & & 738,50 \\
\hline MONTEVIDEU (URU) & 412,00 & - & 417,00 & 445,00 & - & 450,00 & 640,00 & - & 645,00 \\
\hline
\end{tabular}

\begin{tabular}{|c|c|c|c|c|c|c|c|}
\hline PETROBRAS & \multicolumn{3}{|c|}{ IFO 380CST } & \multicolumn{3}{|c|}{ IFO 180CST } & MGO \\
\hline ANGRA REIS-R.J & 352,00 & - & 353,00 & 383,50 & - & 384.50 & 729,50 \\
\hline MADRE DEUS-BA & 350,00 & - & 351,00 & 381,50 & - & 382,50 & $729,5 \mathrm{~d}$ \\
\hline RIO DE JANEIRO-RJ & 322,00 & - & 323,00 & 353,50 & - & 354,50 & 701,50 \\
\hline RIO GRANDE - RS & 332,00 & & 333,00 & 363,50 & & 364,50 & 748,50 \\
\hline SAO SEBASTRAO-SP & 352,00 & & 353,00 & 383,50 & & 384,50 & 722,50 \\
\hline
\end{tabular}

"Tankers working for Petrobras - EX PIPE

RMK500 IN SANTOS $313,00 \quad-\quad 314,00$

Best Regards,

HEAD OFFICE BUNKERING DEPARTMENT Av. Henrique Valadares, 28 Torre A 10 andar CEP 20231-030 - Rlo de Janeiro - R.J - Brazl Phone: + $55212166-8377$

A.O.H. MOBILE NUMBER +5521972106272

LONDON OFFICE

Petrooras Europe Lto

4th floor, 20 North Audley Street

London W1K $6 \mathrm{WL}$

Mrs Ana Beatriz

PHONE' + $442030730790 / 2030730760$ sustchboard

FAX: +44203073078

Moble: + 4407738766897

E-mal: ana.rossettogpetrobras.com

Mr Marco Antonlo Costa Tritto Phone: + 44 (0) $203073075 \%$

Moble: + 447912307535

E-mal: mactritto @petrooras.com 
ANEXO C: PDA - PROFORMA DISBURSEMENT ACCOUNT

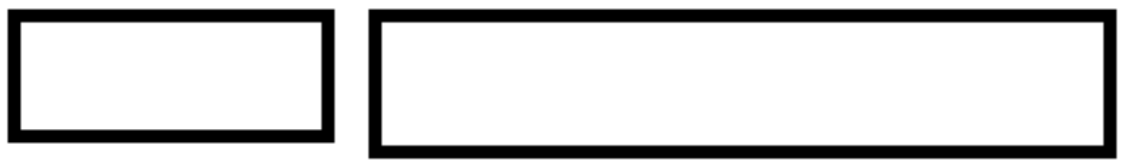

\begin{tabular}{|c|c|c|c|c|c|c|c|}
\hline \multicolumn{8}{|c|}{ PROFORMA DISBURSEMENT ACCOUNT } \\
\hline Port/Berth: & & & & Customer: & & Appointment type: & Full Agent \\
\hline Service type: & \multicolumn{3}{|c|}{ LOADING } & Currency: & USD & ROE: & 3,1088 \\
\hline Commodity: & \multicolumn{3}{|c|}{ Stell Products } & Cargo Quantity: & 35.000 & Days (5tay in port): & TBI \\
\hline Vessel/ Voy: & \multicolumn{2}{|c|}{ PANAMAX TBN } & Flag: & MALTA & ETA: & \multicolumn{2}{|c|}{$\overrightarrow{T B I}$} \\
\hline DWT: & 74.204 & GRT: & 38.727 & NRT: & - & BOW TRUSTER & $\mathrm{n} / \mathrm{a}$ \\
\hline BEAM: & 32,00 & LOA: & 225,00 & DEPTH: & & & \\
\hline
\end{tabular}

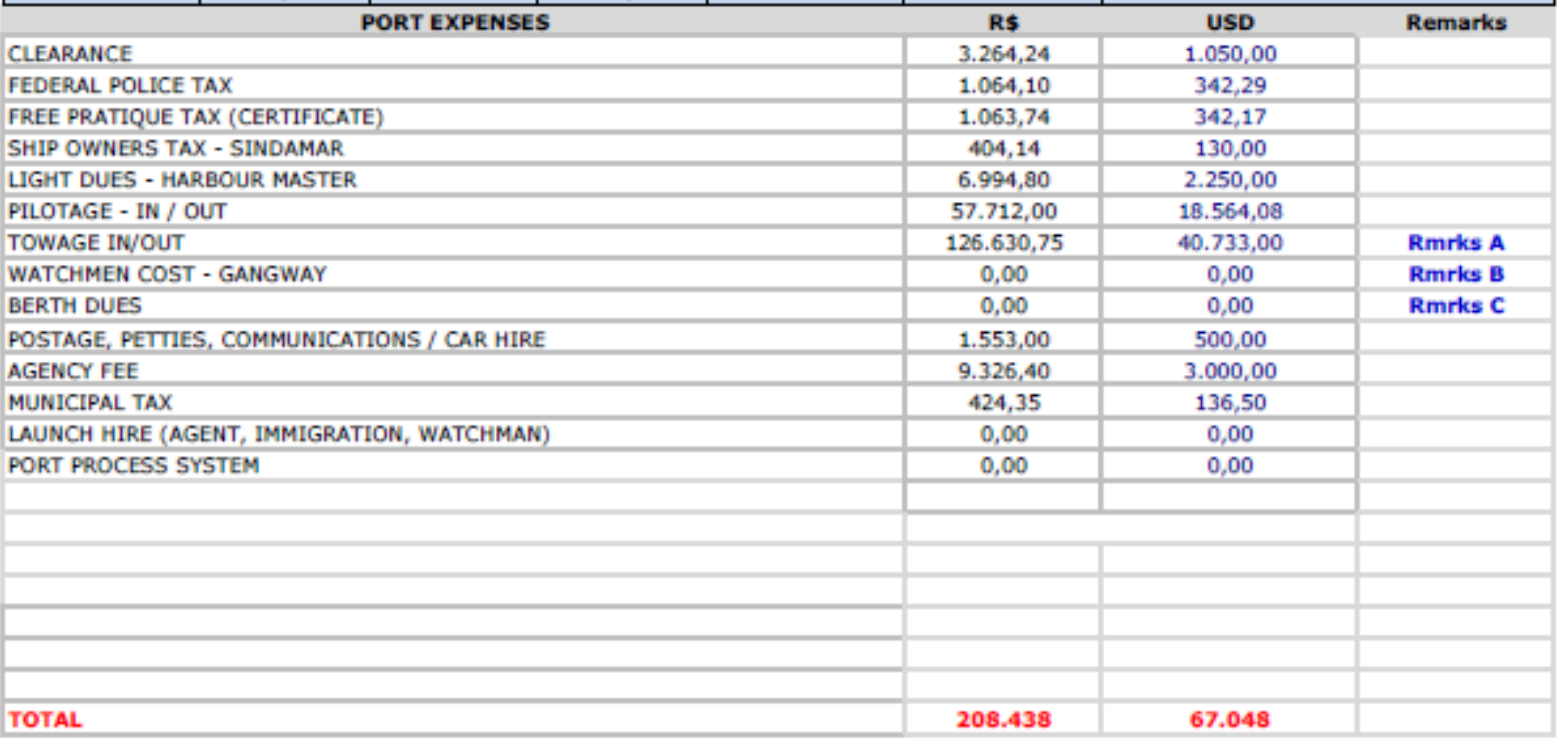

Please note that this is a pro-forma disbursement sccount only. It is intended to be a estimste of the actual Disbursement Account. Whilst Wilson, Sons Agends Please note that this is a pro-forma disbursement sccount only. It is intended to be a estimste of the actual Disbursement Account. Whilst Wiscon, Sons Agenda disbursement may, and often does, for various reasons beyondsinbsp; ;our control, vary from the pro-forma disbursement account.

You are required and are liable to pay upon demand, the full amount described and shown in the actual disbursement account. This duty exists regardless of any dirference between the figures in this pro-forma disbursement sccount and the actual disbursement account.

For the svoidance of doubt, this pro-forma disbursement sccount is not a contractual document. Remarks:

We kindly draw your attention to the below remarks:

(A) Towage: $30 \%$ Discount as per official Tarif in force.

(B) Terminal does not charge watchmen cost.

(C) $=$ Terminal does not charge wharfage cost. 